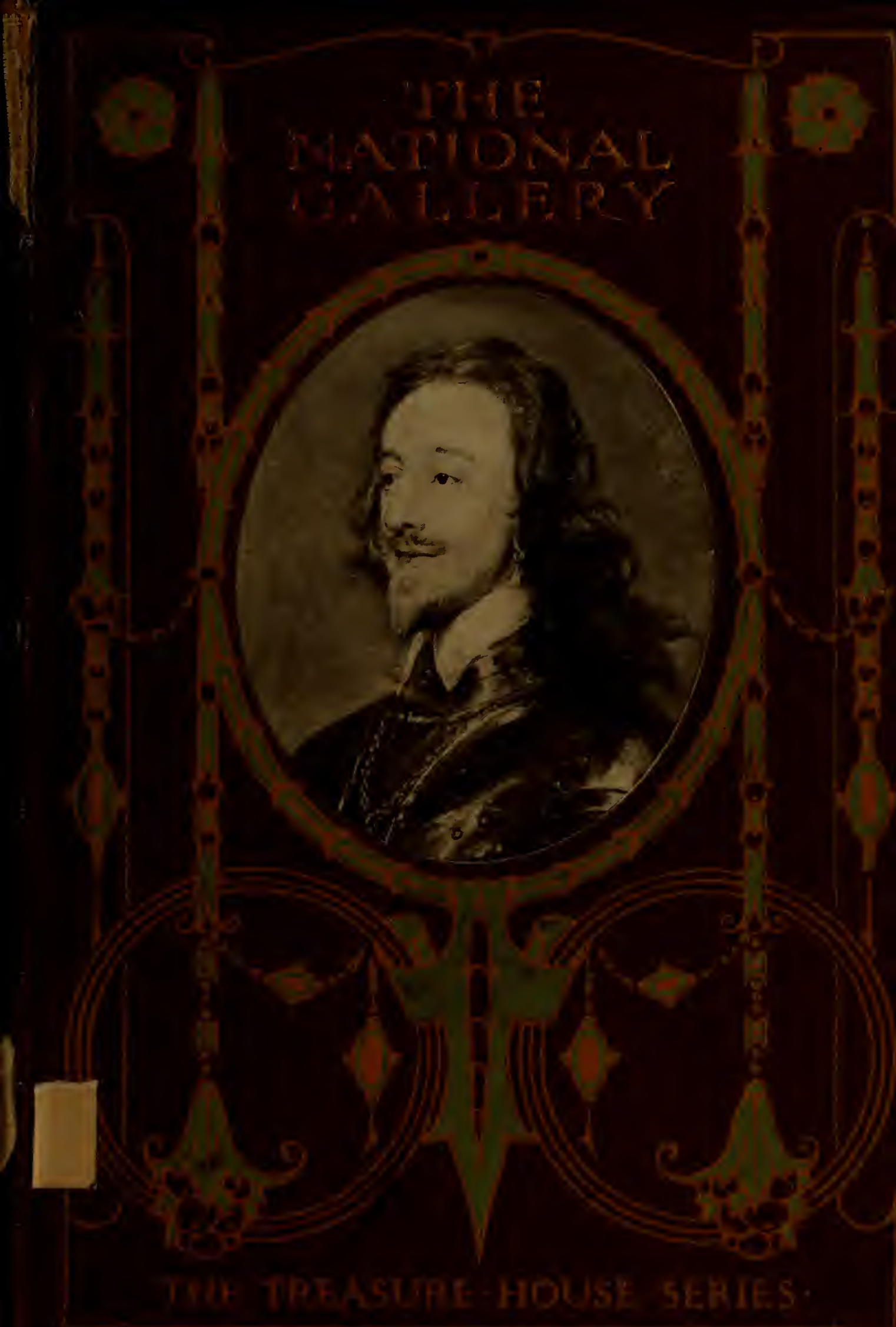




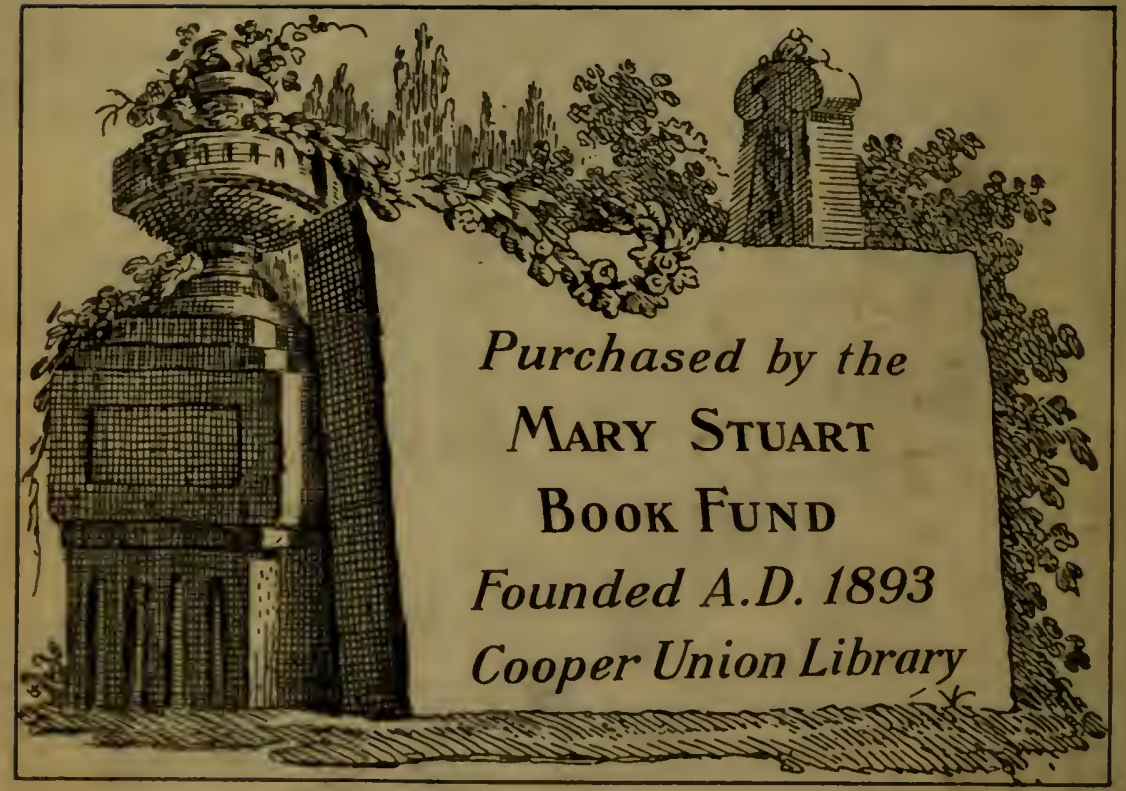




$$
\begin{aligned}
& 708.2 \\
& C 799
\end{aligned}
$$

\section{THE NATIONAL GALLERY}





.

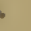




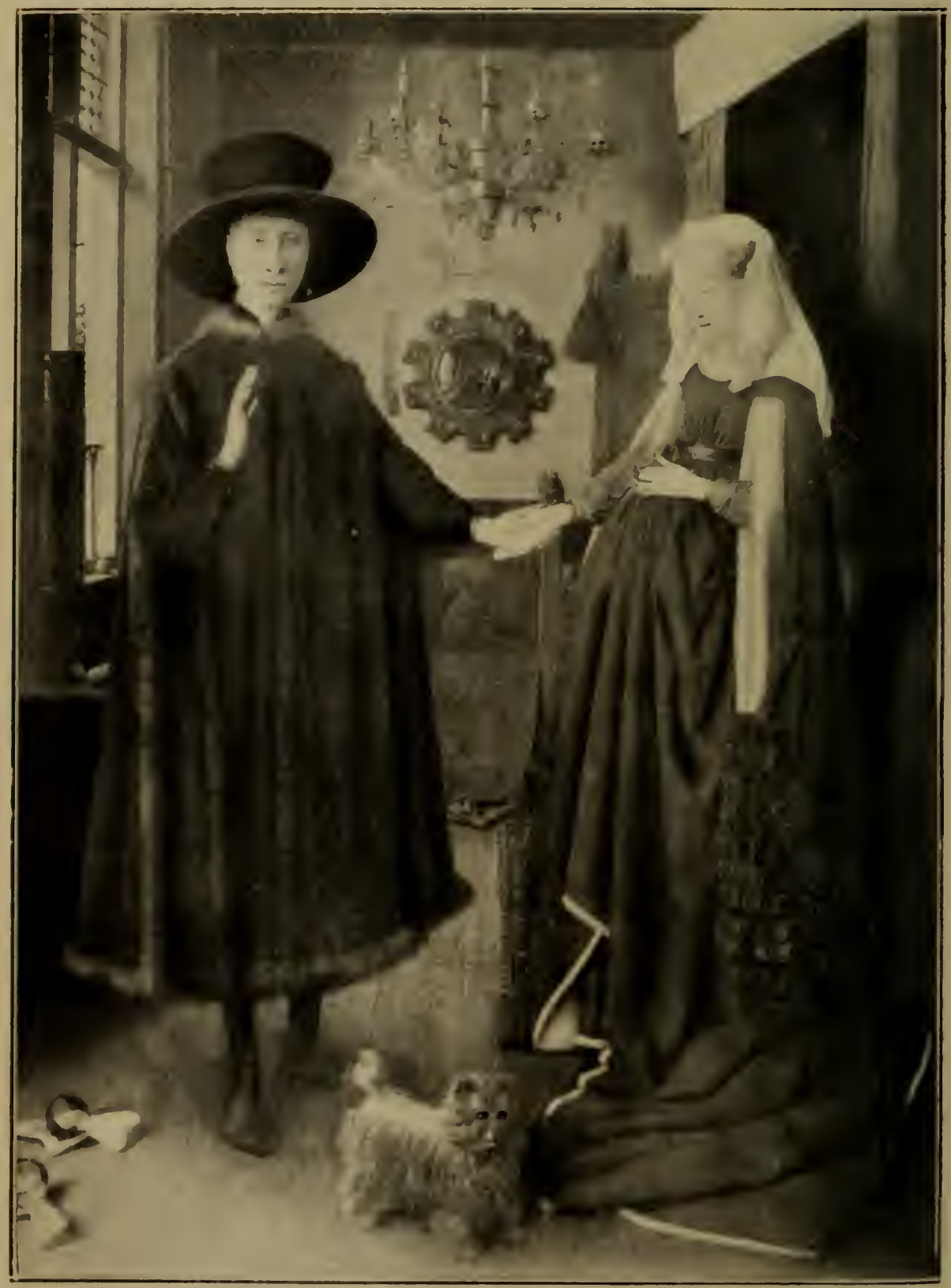

"PORTR.ITS OF JRIN IRNOLFI AND JEANXE DE CHENANY HIS WIFl:" (1 1 ti)

แY JA. VAX EYCK 


\section{THE}

NATIONAL

GALLERY

BY

ALICE CWORKRAN

AUTHOR OF " DOWN THE SNOW STAIRS," ETC.

WITH ILLUSTRATIONS

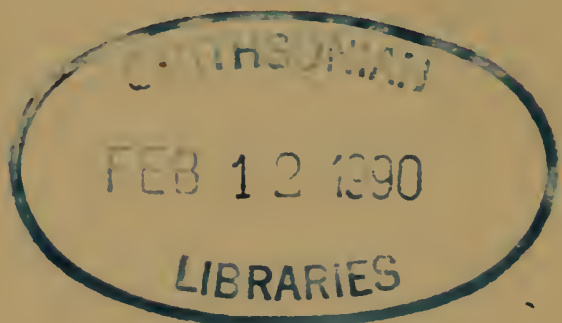

\section{LONDON}

Wells Gardner, Darton \& Co., Lto.

3 Paternoster Buildings 


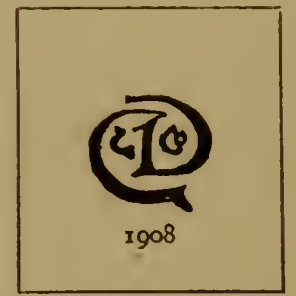




\section{2

\section{INTRODUCTORY NOTE}

I HAVE to record my gratitude to the many writers whose works have helped me to compile this guide to our National Gallery for young folk - to Vasari, to Messrs. Crowe and Cavaleschi, to Dr. Waagen, to M. Charles Blanc, to Messieurs de Goncourt, to Monsicur L. Viardot, to Monsieur Chesneau, to Monsieur de Sizeranne. I have also referred to Diderot's letters and criticisms; to the Official Guides to the National Gallery, and to many other authorities read in handbooks and articles which I cannot enumerate. I owe an especial debt of gratitude to Mr. E. T. Cook for his admirable handbook that was a store of inspiration to me, to Mr. Cosmo Monkhouse, and Mr. Frederick Wedmore. Mr. Ruskin has been my unfailing guide, and if I have sometimes ventured to differ from him as a critic, I have never differed from the noble spirit of his teaching.

A. C.

The Illustrations in this volume and on the cover are from photographs taken by Messrs. W. A. Mansell \& Co., Oxford Street, a list of whose publications will be found at the end of the volume.

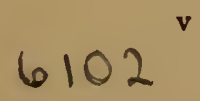




\section{CONTENTS}

ChApter I

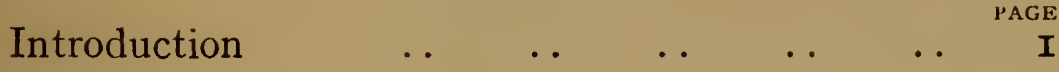

Chapter II

$\begin{array}{lllllllll}\text { Vestibule } & \ldots & \ldots & \ldots & \ldots & \ldots & \ldots & 5\end{array}$

Chapter III

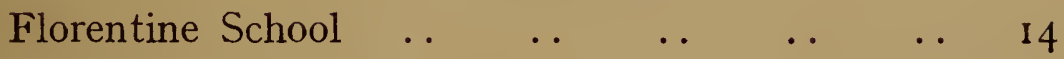

Chapter IV

Florentine School (continued) $\quad \ldots \quad \ldots \quad \ldots \quad \ldots 25$

Chapter V

$\begin{array}{llllllll}\text { Michael Angelo } & \ldots & \ldots & \ldots & \ldots & \ldots & 36\end{array}$

Chapter VI

Leonardo da Vinci $\ldots \begin{array}{lllllll} & \ldots & \ldots & \ldots & \ldots & 4 \mathrm{I}\end{array}$

Chapter VII

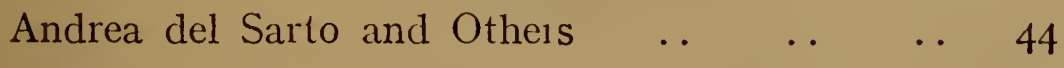

Chapter VIII

Mostly about the School of Siena $\quad \ldots \quad$. . 49

Chapter IX

$\begin{array}{lllllll}\text { Umbrian School } & \ldots & \ldots & \ldots & \ldots & \ldots & 53\end{array}$ 
viii THE NATIONAL GALLERY

Chapter X

Umbrian School (continued)

PAGE

57

Chapter XI

Umbrian School (continued)

$$
\text { . . . . . } 64
$$

Chapter XII

The Ferrarese and Bolognese School $\quad \ldots \quad \ldots \quad 70$

Chapter XIII

Paduan School: Andrea Mantegna _. $\quad$.. 79

Chapter XIV

$\begin{array}{lllllll}\text { Venetian School } & \ldots & \ldots & \ldots & \ldots & \ldots & 82\end{array}$

Chapter XV

$\begin{array}{lllll}\text { Venetian School (continued) } & \ldots & \ldots & \ldots & 88\end{array}$

Chapter XVI

Paul Veronese, Sebastian del Piombo, and the Great Portrait Painters

. 95

Chapter XVII

Schools of Lombardy: Three Great Painters .. I02

Chapter XVIII

Decay and Decline ..

CinApter XIX

$\begin{array}{lllllll}\text { School of Spain } & \ldots & \ldots & \ldots & \ldots & \text {. } & \text { II }\end{array}$

Chapter XX

Velazquez and Murillo

. II 5 
CONTENTS

ChAPTER XXI

Art of the Low Countries $\ldots \ldots$

Chapter XXII

$\begin{array}{lllllll}\text { A Great Trio } & \ldots & \ldots & \ldots & \ldots & \ldots & \text { I30 }\end{array}$

Chapter XXIII

$\begin{array}{llllllll}\text { Dutch Art } & \ldots & \ldots & \ldots & \ldots & \ldots & \ldots & \text { I3 } 8\end{array}$

Chapter XXIV

Dutch School (continued) $\ldots \quad \ldots \quad \ldots \quad \ldots \quad \ldots \quad I_{42}$

Chapter XXV

German School

$\begin{array}{llllll}\text {. } & \ldots & \ldots & \ldots & \ldots & \text { I } 55\end{array}$

Chapter XXVI

French School $\quad \ldots \quad \ldots \quad \ldots \quad \ldots \quad \ldots \quad \ldots$ I6I

Chapter XXVII

French Artists of the Eighteenth and Nineteenth Centuries

$$
\text { . } \quad \ldots \quad \ldots \quad \ldots \quad \ldots \quad I 67
$$

Chapter XXVIII

English School

$$
\text { . } \quad \ldots \quad \ldots \quad \ldots \quad \ldots \quad I 76
$$

Chapter XXIX

English School (continued) $\quad \ldots \quad \ldots \quad \ldots \quad \ldots \quad \mathbf{I} 83$

Chapter XXX

Painters of the Norwich School and Others

Chapter XXXI

English School: Constable 
Chapter XXXII

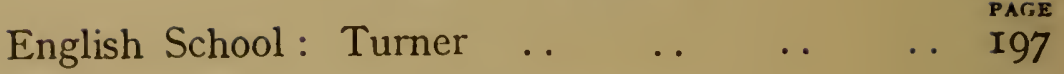

Chapter XXXIII

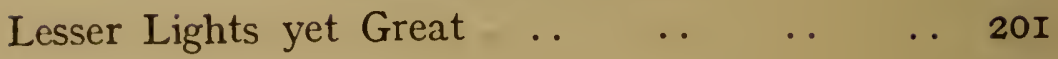

Chapter XXXIV

$\begin{array}{llllllll}\text { Conclusion } & \text {. } & \ldots & \ldots & \ldots & \ldots & \ldots & 208\end{array}$ 


\section{LIST OF ILLUSTRATIONS}

Portraits of Jean Arnolfini and Jeanne de Chenany,

his wife

Jan van Eyck .. Frontispiece

The Death of Procris .. . . Piero di Cosimo

PAGE

The Madonna and Infant Christ, St. John the

Baptist, and Angels Michael Angelo Buonarroti 40

The Virgin of the Rocks Leonardo da Vinci 42

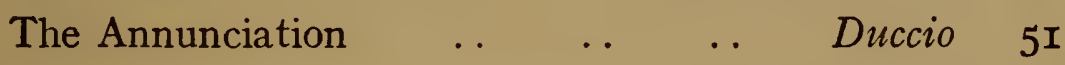

Vision of a Knight $\quad . \quad$.. Raphael Sanzio 60

The Virgin with the Infant Christ, and St. Anne

enthroned, surrounded by Saints Francia 76

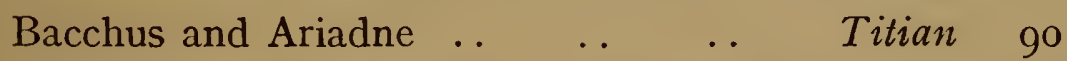

The Vision of St. Helena $\quad$. Paolo Veronese 96

Portrait of the Spanish Admiral, Pudilo Pareja

Velazquez II7

Head of Charles I. $\quad$. $\quad \ldots \quad$. . Van Dyck

The Avenue, Middelharnis, Holland .. Hobbema I5o

The Horse Fair $\quad$. $\quad$. . $\quad$ Rosa Bonheur I74

Heads of Angels _. Sir Joshua Reynolds $\quad$ I79

The "Fighting Téméraire" tugged to her last

$\begin{array}{lllll}\text { berth to be broken up } & \text {. } & \text {. } & \text { Turner } & \text { I98 }\end{array}$

Dignity and Impudence ${ }_{\mathrm{xi}}$ Sir Edwin Landseer 206 



\section{THE NATIONAL GALLERY}

\section{CHAPTER I}

\section{INTRODUCTION}

"Art is long and time is fleeting."

When we step out of Trafalgar Square into the National Gallery we step into the midst of beauty. Two massive pale green marble pillars form the approach to the vestibule; their carved capitals are of alabaster from Derbyshire, their base of Aberdeen granite. Delicate yellow marble, like sunshine caught in stone, lines the side walls of the stair-flight. It is the beautiful giallo-antico of ancient Rome. Red columns resembling jaspar, coming from the west of Algiers, support the arches of the ceiling; their pedestal is of marble from the Apennines. It is a fit entrance to the shrine of these world-famous pictures that are in a sense the work of all the greatest painters the world has known. All that is best in their work has come down into the art of our time.

I want you to imagine that, together, we are visiting the National Gallery, room by room, chatting as we go along of the various pictures, of the artists who have painted them, of their sub- 
jects, talking of the different schools to which they belong.

"What is a school ?" you ask me.

No, it is not a place where you learn your lessons, where there is fagging and games, and rewards awarded, and punishments administered. A school of painters means a group of artists working under the influence of a leader-a painter, who has brought some new view of art into the world. One, for instance, brought colour and the harmony of colour, another brought what is called composition-that is arranging figures to the best advantage so as to serve the purpose of the work; another taught how to look at landscape and so on. Perhaps it would be more correct to say that to those who worked under the overpowering influence of a master, the new thing his genius had brought seemed such a great thing that they were content to go on doing it as if there were nothing more to be done. They and their master formed what is called a "school." A school, therefore, is founded on some new view of art which comes as a priceless addition to the great accumulation of art-principles, contributed by all the other schools that have gone before. It is a sort of hoard of treasures.

In early art the subject was the first consideration. In the thirteenth century there was a great awakening of art in Italy. Cimabue and Giotto founded the Florentine school. A great many schools descended from it. All began by being religious. Painting, it may be said, was the hand- 
maid of the Church, and the Catholic Church permeated the life of the people. The subjects demanded were taken from legends of saints. The Madonna reigned supreme in art. In the fifteenth and sixteenth centuries, when perspective, composition, the science of light and shade had been mastered, artists began to treat allegorical and mythological subjects, and above all portraiture.

The different schools that were affected by the great Florentine revival are the Sienese, the Ferrarese, the Bolognese, the Umbrian, the Paduan, and that of Lombardy, all culminating in the Venetian school in which art seemed to reach its climax. All represent a larger outlook upon the life of the people. Italy and after it Spain represent the Catholic influence in art. Every church contained numerous altars above which was raised a masterpiece. The art of the South was pre-eminently a Catholic art.

The art of the North was essentially a Protestant art, caring little for legends of the saints and the Madonna, caring very much for human beings and for the love of country. The Flemish school is a grand school of portraiture. It numbered Van Eyck, Rubens, Van Dyck among its supreme masters.

The Dutch school was developed only after the Reformation, and its painting is entirely inde-. pendent of the Catholic Church, its art independent of Church patronage. Patriotism is the strong inspirer of Dutch genius; portraiture, landscape and genre painting (the painting that illustrates 
the modest incidents of home life) were its favourite forms of art. In portraits the Dutch masters painted the portraits of their burgomasters; in landscape they set themselves to preserve every feature of their low-lying, level pasture land, in genre painting all the simple avocations of the home-loving national life.

The German school shows the serious sincere ideal of the German folk. It was of short duration. The Thirty Years War put an end to the florescence of art. Albert Dürer was the great Lutheran painter, Holbein was the king of portrait painters. Then came the French school born of classic traditions, a school full of cultured, charming artificiality.

Afterwards, towards the end of the seventeenth century, came the English school. It is strong and individualistic, as is the nation. It had three foremost painters for its leaders-Hogarth, Sir Joshua Reynolds, and Gainsborough. 


\section{CHAPTER II}

\section{VESTIBULE}

But at any rate $I$ have loved the season Of Art's spring birth so dim and dewy; My sculptor is Nicolo the Pisan ; My painter-who but Cimabue?"

HERE we are in the National Gallery. Oh these wonderful pictures! How beautiful they are, how soothing is their colour; we feel what the Americans call "good" in this lovely atmosphere. Now I am going to speak to you about these works of art-not about them all or nearly all-but about those that I think you would care for most and those that are important for you to know something about. I must not trouble too much to keep to the order of the rooms, although I will keep to it as far as possible; but there are so many changes in the hanging of the pictures that confusion ensues when we look for them in the rooms. I shall mention them by their numbers as these never alter. The artist who founded the Florentine school was Cimabue, and he is now in Room III. Let us seek for him there, as I am anxious to trace for you the history of the Florentine school from the beginning. 
Cimabue's picture, "The Madonna and Child" (565), marks the beginning of the revival of art in Italy and in the world. It is the first picture that we have of the Florentine school. The Byzantine influence is strong upon it. It is important that you should understand what I mean by the Byzantine influence. In the fourth century, the Roman Empire had been broken up into two great divisions-the Eastern Empire and the Western Empire. The Western Empire had Rome for its capital, the Eastern had Constantinople or Byzantium. As trouble continued to overwhelm Italy from without and from within, the centre of civilisation was gradually transferred to Constantinople. Then when Italy had been broken up into separate republics, when peace returned to the country, it was found that during that time of warfare the buildings had been allowed to fall into decay, and, what was of greater importance, there were no artists in Italy fitted to undertake their restoration. Art had taken refuge in the Byzantine Empire. About the twelfth century wealth and happiness had come back to Italy. Florence especially was prosperous, and the gaiety and courtliness of its life had returned.

The heads of the State wished to rebuild and to re-decorate the ruined buildings, but there was no Florentine who could undertake the task, so they sent to Constantinople for Greek artists.

Byzantine art was a curious product. It was very conventional. Greek artists always worked from a preconceived idea, and they never looked 
at nature to correct this idea. They largely encrusted their work with gold; they put gold instead of light on the dresses, gold on the halos, gold on the crowns, gold in the background. It was garish, even splendid in effect, but it was not nature. For everything there was a readymade model, and from that model the artists never departed. The faces they painted were always the same faces, with goggling eyes and rigid lips. The figures were without grace, they were gaunt and archaic, but gold made up for everything, and gold was lavishly used.

To Florence, therefore, came Greek painters and Greek architects to rebuild the churches and to decorate the walls and altars. The inhabitants of the town watched the painters at work; and in the crowd there was a little lad, the member of an illustrious family. He was born about I240, and he was named Giovanni Cimabue. His father wished him to attend the classes held by a relative in the convent of Santa Maria Novella, but Cimabue did not care for that kind of learning; his heart was with the artists in the chapel. When he could not get there he covered the leaves of his lessonbooks with drawings of men and women, of horses and houses, but whenever he could escape he would run off to watch the Greek artists at work. Don't you fancy you can see the lad watching, with all his soul in his eyes? The father felt that the boy had a vocation and no longer opposed his bent. Cimabue was apprenticed to the Greek artists. He was happy now; he could devote all 
his time to his beloved art. His masters never looked to nature, but Cimabue was full of observation. For nigh three hundred years no one in Italy had drawn from life. Cimabue studied nature; his pictures were very grotesque, but it was a right impulse he gave to art; instead of following convention he attempted the representation of things as they were. He tried to paint what he saw, his Madonnas, his angels are gaunt, the drawing is almost childish, but there is in it a touch of reality. It was because of this truth that he brought into the world-to study from nature direct-that his pictures meant so much to his contemporaries.

He painted a Madonna, with the shadow of pain in her eyes, carrying the Babe on her knee; about her and the Child are angels. All the citizens of Florence turned out and carried Cimabue's picture in triumph through the city to the church of Santa Maria Capella. The citizens donned holiday attire, the children threw flowers, the youths sounded trumpets, the joy bells rang, all the dignitaries of Church and State accompanied the picture on its way. Lord Leighton has painted a beautiful representation of this scene. The way Cimabue's Madonna went has been called the suburb of gladness, and still it is called the "Borgo Allegri."

The "Madonna and Child" (565), by Cimabue, is a colossal Madonna, very stiffly drawn, but her eyes are sad, and, with a tender gesture, she clasps her Child. Time has very much injured the 
picture's colour; it has worn away the flesh tints; it has left uncovered the green foundation, yet there is truth in it, because Cimabue studied from nature. He became the founder of the Florentine school, to which Botticelli and Lippo Lippi belonged, Piero di Cosimo, and Andrea del Sarto, of incomparable grace, the school that blossomed into the genius of Michael Angelo, into the divine grace of Leonardo da Vinci.

We shall now return to the vestibule. Giotto, Cimabue's pupil, carried further than his master did the study of nature, and shares with him the glory of being head of the Florentine school. He was the son of a shepherd who lived in Vespignamo, a hamlet fourteen miles from Florence. The lad used to take out his father's flocks to pasture. One day, when he was about ten years of age, he drew, as was his wont, with a sharp stone for pencil upon a smooth rock. Cimabue passed that way and stopped to see the little fellow's work; he was so pleased with it that he asked Giotto if he would go to Florence to learn there how to draw and paint. Giotto was wonderstruck and answered he would willingly go if his father allowed him. Then Cimabue went to the shepherd's hut and asked if he might take the child back with him and teach him art. Permission was granted, and the boy from that day prepared to become a painter. In another version of the meeting of Cimabue and his future pupil, it is said that Giotto's father had apprenticed the lad to a woolmerchant, and, one day asking news of his son, he 
heard that he used to spend all his time at the studio of Cimabue. It was no use to oppose his bent for art; the father took him away from the wool-merchant, and placed him under the care of Cimabue.

The joy of Giotto! He might work all day without pause! Very soon his ardour made him outstrip his master. He drew straight from life, and he drew everything. He formed a friendship with the poet Dante, painting his portrait. Poet and painter, how ennobling was their intercourse!

Giotto's most notable works are his frescoes at Assisi. Saint Francis, who looked upon all created things as his brothers and sisters, who wrote canticles to the sun, to the birds, whom the very wolves obeyed, was dead. He was buried in the church on the hill. Giotto was entrusted by the prior of the order of the Dominicans to paint the frescoes illustrating the miracles and life of St. Francis of Assisi.

We have nothing authentic from Giotto's hand. But we have pictures that undoubtedly belong to his school-thus (276), placed in the vestibule, shows the heads of St. John and St. Paul bowed in adoration. They are part of a fresco; some say that they are portraits. It is the beauty of the expression, the fervour of the look, that makes them dear to us. No. (568) is "The Coronation of the Virgin." Neither is this picture held to be by Giotto, but, again, it is by a member of his school. There is a charming and familiar loveliness in the 
incidents depicted; the human element is strong, as it is in all that Giotto painted. Thus it was that, although Cimabue founded the school of Florence, Giotto went further than he did in the study of nature, and all the artists of this period were called Giottesques.

Margaritone (I2I6-I293) was the last of the Italians who painted according to the Greek or Byzantine manner. This picture, "The Virgin and Child "(564), with incidents taken from the "Lives of the Saints," is placed in the vestibule. It speaks to us in symbols. The child Christ is blessing the faithful. He holds in his left hand the roll on which are inscribed the names of the saved. The Virgin is surrounded by an aureole, almond-shaped, used for her only when she holds the Child. Outside are placed the Angel, the Ox, the Lion, and the Eagle-emblems of the four Evangelists. On either side of the panel are pictured incidents from the "Lives of the Saints," eight in number. How quaint and grotesque is the symbolism; it is almost childish in execution. Here, for instance, is St. John the Evangelist, apparently in a hip-bath of seething oil, blessing with uplifted hand his persecutors; a little further we see him resuscitating Drusiana; there is St. Benedict rushing into a thicket of briars and nettles to rid himself of the thought of a beautiful woman that is impeding his prayers, and St. Nicholas of Bari is also there preaching to the sailors. Further on is St. Catherine being beheaded, her body buried by angels on Mount Sinai, and strangest of all 
these strange little pictures is that of St. Margaret in prison swallowed and disgorged by the dragon.

Margaritone died when he was aged seventyseven. He was weary of life; he had survived the art of his youth and the taste of his time, for taste had turned from the love of convention to the love of the new ideals in art. Cimabue and the shepherd's son, Giotto, had taught their generation to care only for the truth of nature. Men were beginning to look to the present rather than to the past, to the teaching of the actual rather than to the teaching of the symbol, and Margaritone had been left behind in the march of the human spirit towards progress.

Orcagna (I308-I368), painter, poet, sculptor, and architect, is the next painter whose works I want you to look at. His name means the "Archangel," and although his pictures are stiff and show a want of knowledge of anatomy, they are imbued with the solemnity of great faith. His virgins and angels have a certain elegant sweetness of pose and expression. He drew with force and energy, and he finished every part of his picture with care and delicacy. In this altarpiece (569), placed in the vestibule, the "Coronation of the Virgin," we find these qualities exemplified. In the centre Christ is crowning His Mother. How dignified and graceful is the Virgin's pose, as she bends her head to receive the crown which her son is placing upon it. Angels are around, some kneeling, some playing musical instruments, all worshipping the Lord and His Mother. In the 
two compartments, one on the right and one on the left of this central panel, saints are kneeling in adoration. On the left is Peter carrying the model of the church St. Peter Maggiore, for which the picture was painted. Saints and apostles are there, and among them are women-St. Elizabeth of Hungary, Mary Magdalene, and St. Catherine of Alexandria. It is a picture full of adoration and of a sense of character. You will find nine small pictures (570 to 578), portions of this altar-piece, helping to tell the great story of the redemption of man. All these pictures are more or less rudely drawn, but they reveal to us why the painter was called "Archangel." His mind dwelt on heavenly themes, and he was impatient of others less exalted. We have not many details of Orcagna's life. 


\section{CHAPTER III}

FLORENTINE SCHOOL

" Washed by the morning's water gold Florence lay out on the mountain side."

WE push the swing-door open and we enter. Most of the pictures at the first glance will strike you as religious pictures, for art was the handmaid of religion. The supreme artist expresses best what are the spiritual influences of his time, and therefore you will see how powerful was the influence of the Catholic Church during the Middle Ages. Men and women were always thinking of the Jewish maiden, so pure, so pious, so tender, whom God considered worthy to be the Mother of His Son. You will see the Madonna continually painted - sometimes she is seated on a throne, sometimes she is lowly adoring her child, sometimes she is simply the human mother rejoicing in her baby boy, or weeping broken-hearted at the cross. In Italian and in Spanish pictures you will continually see the Madonna depicted, because in these two countries the influence of the Catholic Church was strongest.

But all the pictures here are not religious pictures. There are many of heathen gods and goddesses, and there are portraits. Near the pictures of the Madonna, or of the legends of the saints, you will 
find, for instance, one of the heathen gods, and that is because there was another influence at work among painters and lovers of art. The fifteenth century saw the rebirth of learning-what we call the Renaissance. I shall not enter into the causes of this rebirth except to ascribe it to the invasion of Constantinople by the Turks and the dispersion of the treasure of art and literature hoarded in the city. Plato and Aristotle, Ovid and Virgil, the great poems of Homer, became the favourite study of the scholars of the time. They laid aside their canonical books to read the classics. They put away austere thoughts; a great joy of life seized the Italian nation. It delighted in lovely things as it had not done before, for before it had been absorbed in the high truths of religion only. The period of the Renaissance is the finest period of art the world has known, and here in this first room we see the struggle of the new spirit and of the old. Of this conflict Sandro Botticelli was the exponent.

Let us begin by looking at the picture of the Virgin and Child by Fra Filippo Lippi (589), who was the master of Botticelli. "Fra Filippo Lippi's art," says Mr. Ruskin, "is the finest out and out art which ever man did." $\mathrm{He}$ was the son of a butcher, and he was strong and full of life. $\mathrm{He}$ early became an orphan, and he was placed by his aunt in a Carmelite convent; then, when he was in his early teens, he was persuaded to take the vows. But he was faithless to them, for when he went to paint an altar-piece at the convent of Santa Margherita, at Prato, he fell in love with one of the 
sisters, rather with a young novice-the charming Lucretia Buti, who had sat for the Madonna in his picture. We are told that he ran away with her at a convent festival, in which she was to bring the girdle to the Madonna. There are other pictures by him in this room, and in each you will find the same realism of representation and the same strong religious fervour of idea. There is something very vital about his art. It is an art more than four hundred years old, for Fra Lippi was born about I406 and died I469. And yet we seem through it to know the artist; he loved human beings, he loved life, he was always watching the people around him, he was curious about them. His patron was Cosmo de' Medici, whose portrait is here painted by Angelo Bronzino (704). It is a small portrait, but you will see that his face expresses all that he was-cruel to his enemies, intellectual, generous towards those whom he patronised.

Let us first look at Fra Filippo Lippi's picture, "The Virgin and Child" (589). It is a strange and beautiful conception, a wonderful symbol; all the details in it are full of nature. It gives us the key to Fra Lippi's genius, which was both ideal and realistic. We see the Virgin sitting out of doors, and an angel comes and presents to her the infant Christ. It is not the Virgin who holds the Child, but the angel who brings it, as a symbol that $\mathrm{He}$ is more than a human babe, that $\mathrm{He}$ is the Redeemer of the world.

The other pictures by Fra Filippo Lippi in this gallery are "The Vision of St. Bernard" (248). 
The Virgin, surrounded by children, appears to the saint as he sits writing. It is an open-air scenethe table at which St. Bernard, wearing a white Carmelite costume, sits is formed by a rock on which are placed his inkstand and his paper. $\mathrm{He}$ is looking up, gazing at the gracious apparition, surrounded by a procession of angels. The Virgin is a benignant presence. She might be a tender woman answering one who calls her, and the little angels about her are human children. Then there is the "Annunciation" (666), at present in the second room. In a charmingly furnished interior the Virgin is sitting. Beyond, on the left, we have a glimpse of a garden full of flowers. Fra Filippo evidently loved flowers, for he paints them so lovingly; from the garden, steps an angel, who, with a graceful gesture, proclaims to Mary her future motherhood. Above the young girl's head a mysterious hand appears, from which a dove is loosened and descends in a ray of golden light. The companion picture (667) is "St. John the Baptist and Saints." This is the loveliest picture of all, I think. I want you to observe the details, the greenery of the garden, the marble bench, the light and peace over all. It is a serene summer day, full of the glow of delicate sunshine. St. Francis is there with the stigmata, St. Lawrence and St. Cosmas sitting on the right. of St. John the Baptist; St. Anthony and St. Peter the martyr on his left; all are listening to the saint's words. We breathe the warmth of the summer day, we hear the thousand sounds 
of nature-the singing of the birds, the hum of the insects; we smell the fragrance of the exquisite flowers. The joy and peace that the artist felt so many hundred years ago, fill our hearts to-day-the joy of earthly beauty and the peace of the spirit.

In Fra Filippo's pictures you must always look for the beauty of material surroundings; he is very much the painter of light idealising what it touches. The picture of St. John and saints is all suffused with light. In "The Annunciation" the light falls upon the sweet maiden about to become the Mother of God. It is caught up by the angel and repeated by a thousand touches in the room and in the garden.

Fra Filippo died suddenly, some say by poison.

Sandro Botticelli was the pupil of Fra Filippo. In childhood he longed to be allowed to devote himself to art as a career. He was then apprenticed to a goldsmith, and he learned how to handle gold, but he was unhappy until his father placed him with Fra Filippo to learn painting. Sandro won the affection of his master. He was gay; his pictures, full of the delight of life, were full of vigour. Before we begin to look at them I must tell you something of a preacher named Savonarola, who had a tremendous influence over his time. He was a monk, stern, severe, inspired; his voice was harsh, his aspect was austere. When he first began to preach no one listened to what he said, then he went into retreat in order to study and pray. As I have told you, the nobles, the people, and the clergy of Italy had become 
devoted to the new learning. They cared no longer for the Christian virtues of self-sacrifice and detachment from the world's joys; they thought only of the beauty of life. Before he heard Savonarola Botticelli painted nothing but heathen gods and goddesses. "Mars and Venus" (9I5) is a good example of his earlier work. Venus is clothed in delicate white and gold tissue; she lies among flowers, and no one ever painted roses as Botticelli painted them. Near Venus is Mars asleep, satyrs and loves play about; they have got hold of the god's weapons-one of them is shouting in his ear, but he does not heed. What mischievous little imps they look! How full of life they are! A swarm of hornets buzzes round the head of Mars. It is a picture of the ruin brought by lazy pleasure. There are other pictures by Botticelli, painted during his first period; in them Venus is a beautiful woman surrounded by roses and by loves.

Then comes a great difference in Botticelli's art. He had heard Savonarola preach; and the monk was thundering against the pagan influences of the time. He was telling of the visions he had seen of the fair city of God-purity was its light, and obedience to divine law the habit of every life. He spoke of the day of judgment, and the citizens of Florence listened and were afraid. They went about like ghosts wringing pale hands in dread. Savonarola stirred the conscience of his hearers; they lit a great fire at the door of the cathedral, and women threw their jewels into the flames; learned men and youths threw their 
books of poetry, their classics, the works of art that celebrated the pagan gods and goddesses. This was called the great sacrifice. Savonarola founded a company of mourners of "Grumblers," and Botticelli entered that order. $\mathrm{He}$ turned away from the subjects that had been the theme of his art till now-he vowed that he would belong to Christ alone, and his pictures from henceforth were inspired by religion. You will see in this room the picture of "The Nativity"; it expresses all Botticelli's creed. It is Christmas morning and there

\section{. . . "the heaven born child}

All meanly wrapt in the rude manger lies."

Heaven and earth are rejoicing together. See the very animals in the manger are lifting up their voices and joining in the Hosannah. The Virgin is kneeling worshipping her Babe, the shepherds, the kings, are hurrying towards Him, and radiant winged angels are rushing to greet them. They embrace pointing to where the heavenly Child is lying. They seem to be saying " this is the Saviour of mankind," and the crowd is pressing onwards as if nothing could keep it back; and look, the devils, all in amaze, are hiding away in rocks. Above the manger is a glow of dazzling light :-

"The helmed Cherubim

And sworded Seraphim

Are seen in glittering ranks with wings displayed, Harping, in loud and solemn quire,

With inexpressive notes, to Heaven's new born Heir." 
This picture was painted in 1500 , two years after Savonarola had been put to death. The Friar had been executed for seditious preaching; but Botticelli lived to paint the vision that had haunted the monk-the reconciliation of heaven and earth. On the top of the picture there is an inscription in Greek telling that it was painted in "the second woe of the Apocalypse," that the devil was loosened, that afterwards he would be chained, and that we should see him trodden down as we see in this picture.

What a difference between the two Botticellis -between the pagan Botticelli, and the Christian painter who saw all heaven and earth with anointed eyes.

There is another picture by Botticelli (275), a circular picture of the Virgin holding her baby boy on her lap, and of St. John and an angel behind. This picture was painted at a time when Botticelli, while much impressed by Savonarola's preaching, was not yet quite converted to Christianity. The Virgin is very beautiful, but she seems somewhat frightened at being the Mother of the Christ. The Child, a chubby baby, is lying on her knee in all the joyous life of infancy. St. John is watching adoringly behind, and the angel is bowing low to the little one. I want you to notice the delicacy of the painting in all Botticelli's works, how beautifully he uses gold. He was apprenticed to a goldsmith in early life. Notice the way in which it is laid upon the Virgin's veil, upon the bodice of her dress. I would have you note also the energy 
of Botticelli's temperament, expressed by the vehement gesture of the Child in this picture. We see the same force and feeling in the laughing triumph of the children in Mars asleep, in the joy of the angels and the shepherds in the Nativity.

There is a picture of the school of Botticelli (2083), lately added to the National collection by the "Cohen" bequest. It shows the profile of a lovely Florentine woman, painted with the marvellous care with which Botticelli worked. Her auburn hair, her lilac dress and pearl ornaments are models of exquisite workmanship. Behind, at the back of the picture, is an angel carrying a celestial globe, standing, with sandalled feet, tiptoe on our globe, announcing the glad tidings to all mankind that the Redeemer is born.

There is a great picture by Botticelli, "The Assumption of the Virgin " (I 26). It is in Room II. among the pictures by Sienese painters. Critics are not agreed whether Botticelli painted it or not, but they are certain, if not by him, that it was painted by one of his disciples. It is a splendid bit of colour. Christ is on high blessing His mother, who kneels before Him, and on His knee is an open book showing the mystic letters, "Alpha and Omega, the beginning and the end." He stands amongst cherubim and seraphim, saints, apostles, and martyrs, amongst the glorious company of heaven, lauding and magnifying His name. When we sing the "Te Deum Laudamus" on a Sunday we sing what this picture teaches in zones of colour and light. Below is the empty tomb of the Virgin, 
in which blossom pure white lilies, and, by the side, following the custom of the time, are the portraits of the giver of the picture, Palmeira and his wife, kneeling on either side of the sepulchre. Behind stretches the valley of the Arno and the lovely city of Florence.

Another Florentine picture is Fra Angelico's "Resurrection" (663). There we see the spirit of prayer and the spirit of art mingling as they have never mingled before or since. Fra Angelico entered a Dominican convent in Florence when he was quite young, but the spirit of art was in him. He illuminated the breviaries of the brethren, and you will see through his art how illumination influenced him. You will see it in the golden halos round the heads of the blessed, in the shadowless and flame-like colouring of their raiment. Angelico's visions were of the glory of heaven. Before setting to work he always knelt and prayed, asking God and His saints to inspire him. $\mathrm{He}$ could never think of the Passion of our Lord without weeping bitter tears. Thus he painted the sweet faces of angels, the glorified countenances of martyrs and saints, dressing his angels in robes that glitter like flame. The Christ stands above. $\mathrm{He}$ is somewhat weakly drawn; about Him floats the white banner bearing the red cross of the Resurrection. What can be more beautiful than the choirs of cherubim and seraphim that crowd about the Lord, sounding their trumpets, playing their viols, their lutes, and beating their drums. Above, on the right of the Saviour, is the Virgin 
followed by the Apostles; on the left are Abraham with his sword, Noah with the ark, Moses with the tables of the law, Aaron with his name inscribed on his mitre. About are numberless patriarchs and saints. The martyrs carry palms in their hands. Some wear wreaths of roses, others crowns of thorns. At the extreme end, on either side of the picture, are portraits of the brothers Dominican, wearing their black robes, who have joined the company of the blessed. Other pictures by Florentine artists are hung, but these are the finest in the Sienese room. 


\section{CHAPTER IV}

\section{FLORENTINE SCHOOL (Continued)}

"And mark through the winter afternoons,

By a gift God grants me now and then,

In the mild decline of those suns like moons,

Who walked in Florence, besides her men."

FilipPINO LiPPI (I457-I504) was Fra Filippo's son, the "little Filippo," and he too was a painter of genius. He was a very young man when his father died-too young to have learned much from him-and he became the pupil of Sandro Botticelli. His pure and excellent life made him greatly beloved. Vasari, the chronicler of the painters of the close of the fifteenth and of the opening of the sixteenth centuries, whose contemporary he was, tells us " that he was loved by all who had known him, not only for the excellence of his life, but for the courtesy and the amiability of his disposition."

"St. Francis with the Stigmata" (598) is a very characteristic picture by this artist. In it we see the saint, whose bride was Poverty, whose heart overflowed with love for humanity and for all created things, receiving the stigmata. The stigmata is the trace of the wounds that our Lord had 
borne-his lacerated hands and feet, his "riven side." It is a tradition of the Catholic Church that St. Francis meditated so constantly upon the Saviour's sufferings, prayed so incessantly, wept such bitter tears over them, that the Lord himself appeared to him and touched his hands and feet and side. From henceforth St. Francis bore in his person the wounds that his Saviour had borne. Here we see him standing in glory against a gold background, contemplating a small crucifix above. On each side of him are angels playing musical instruments, singing anthems exhorting others to follow the example of the saint. It is a strange picture full of a great fervour.

Let us now look at "An Angel Adoring” (927), a somewhat battered fragment from a large picture. A faded halo is round the angel's head; we can see the trace of wings on the shoulders. How tender is the expression of the face bent in prayer, how tender also is the clasp of the finger tips. Seldom has the expression of adoring prayer been more beautifully rendered; adoration is the note of this painter's work. We have in the National Gallery three pictures of "The Adoration of the Magi" (592), (1033), (II24), by Filippino Lippi. In these pictures we see his love for splendour of costume. According to Vasari he introduces figures in antique garments, in armour, swords, togas; all the paraphernalia of classic antiquity appear in his works. Note especially (in II24) the heralds blowing their trumpets, the ample robes of the three Magi offering gifts. The garments 
Filippino paints are of superb brocade and velvet, his jewels are gems of rare colour, yet as we look we forget all the splendour and remember only the sweet and rapt expression of the adoring faces. The love of the classics touched Filippino, as I have told you it had seized all Italy at the time of the Renaissance. Legends of saints, scenes from the biblical story, formed still the subject of the artist's inspiration, but he clothed his conceptions in the worldly splendour that was so dear to his generation.

I must speak to you of the art of composition that he so skilfully employed; in the "Adoration of the Magi" (II24) that art enabled him to fill his canvas and yet to allow no sense of crowding. Group balances group, and we are surprised to find that there are over seventy figures introduced into a comparatively small picture. Of Filippino's works I should say that they reflect his own nature-so pious, so serene, so interested in the world's spiritual beauty and its progress. I can imagine him with his courteous manner, noted by Vasari, his gentle address, painting these pictures of prayer and of divine love. His art differed very much from that of his father; it differed also from that of his master Botticelli, although it was much influenced by it. We recognise little of his father's care of all the dear humble things of the world-the flowers, the sunlight, the beauty of the lilies of the field-nor does he show intimate appreciation of the meaning of gesture; we see none of Botticelli's vehemence. 
Filippino's art, it seems to me, is all contained in the word "worship." It is detached from the world, while appreciating its glory; it is exalted, pure, and expressive. He died at Florence in April I504, and the inhabitants of the city, in order to show their affection for his gentle and gifted personality, closed their shutters all along the route of the funeral procession.

Let us pause for a moment before the picture, "The Battle of Sant' Egidio" (583), by Paolo Uccello (I397-I479). The painter is called Uccello - the Italian for bird-because of his love for the feathered creation. His family name was Dono. "He filled his home," says Vasari, "with a number of painted birds, cats, and dogs." He loved them all-he loved all animals - but he was poor and he could not keep any.

You have all heard of perspective-the science of foreshortening, of representing things as they look, differently from what they are. It was Uccello who discovered its rules. $\mathrm{He}$ was so interested that he would sit up all night drawing perspective plans, intricate circles, and squares. His wife could not get him to bed. "What a sweet thing perspective is," he would say regretfully when she urged him to come. Vasari thinks that Uccello would have been the most original genius since Giotto, but for that love of perspective - "if he had studied figures and animals instead of wasting his time over perspective; although it is a fine science," he says, "yet he who is devoted to it out of measure wastes his time." 
But Uccello was "bitten with it," as they say, and he persisted in his studies, growing every day more solitary and more eccentric in his tastes. He died in great poverty. Look at this picture, "The Battle of Sant' Egidio" (583). In this battle, Carlo Malatesta, Lord of Rimini, and his nephew Galeazzo, were taken prisoners by Braccio di Montone. Malatesta is depicted on his white horse. He has in his raised hand the stick of command with which he apparently is giving the signal of battle. $\mathrm{He}$ is covered with mail, over which he wears a red mantle embroidered with gold. On his head he has a large biretta worked with flowers in gold. Galeazzo is behind him, seen in profile. He has a beautiful face marked by a peaceful expression; his blonde and abundant hair flows about his neck, and he is attentively following the manœuvres of the combatants. Look at the spirit of the horses as they close in the fight; they seem to tear the ground in their energy; the order has gone forth and the battle is raging in earnest. Behind is a hedge of wild roses-roses bloom notwithstanding the tumult of the fray. In the foreground a knight has fallen wounded. His figure lies prone on the earth, and is an example of Uccello's skill in foreshortening. It is a somewhat grotesque picture, but it is full of movement and spirit. Its importance is to show a new development in art-a new thing brought into the world by the genius of man, and this new thing is the union of science with art. Scientific perspective joined to the emotional side of art. 
"The Death of Procris" (698), by Piero di Cosimo (I462-I52I), is a quaint and interesting picture, full of wonder and full of beauty. I must tell you something of the painter, for he was a singular man. The son of a goldsmith, he was placed by his father to study under a painter named Cosimo, who grew to love him dearly, and whose name he took. Piero di Cosimo, as a youth, was very absent-minded and dreamy. "He was so fond of solitude," says Vasari, "that he had no greater pleasure than to go by himself to solitary places, there to weave visions and to build castles in the air." When his master died, to whom he was greatly attached, Piero would let no one see him. "He lived more like a wild beast than a man," says Vasari. "He would never let his room be swept, or his garden dug or his fruit trees pruned." He loved to see things wild as was his own nature. He eat when he was hungry only. He brought himself to live upon hard boiled eggs, which he would cook by fifties, keeping them in a bag to consume by degrees. Later, when you are older, you will read the noble novel "Romola," by George Eliot, and there you will get to know the painter in his old age; you will understand his genius and his eccentricity, his patriotism, his tender love for some people, his aversion to others. Poor Cosimo, as he grew older, he grew more singular and fantastic. $\mathrm{He}$ loved animals dearly. He used to spend hours watching them, but he loved solitude most of all. He became more morose as the shadow of years 


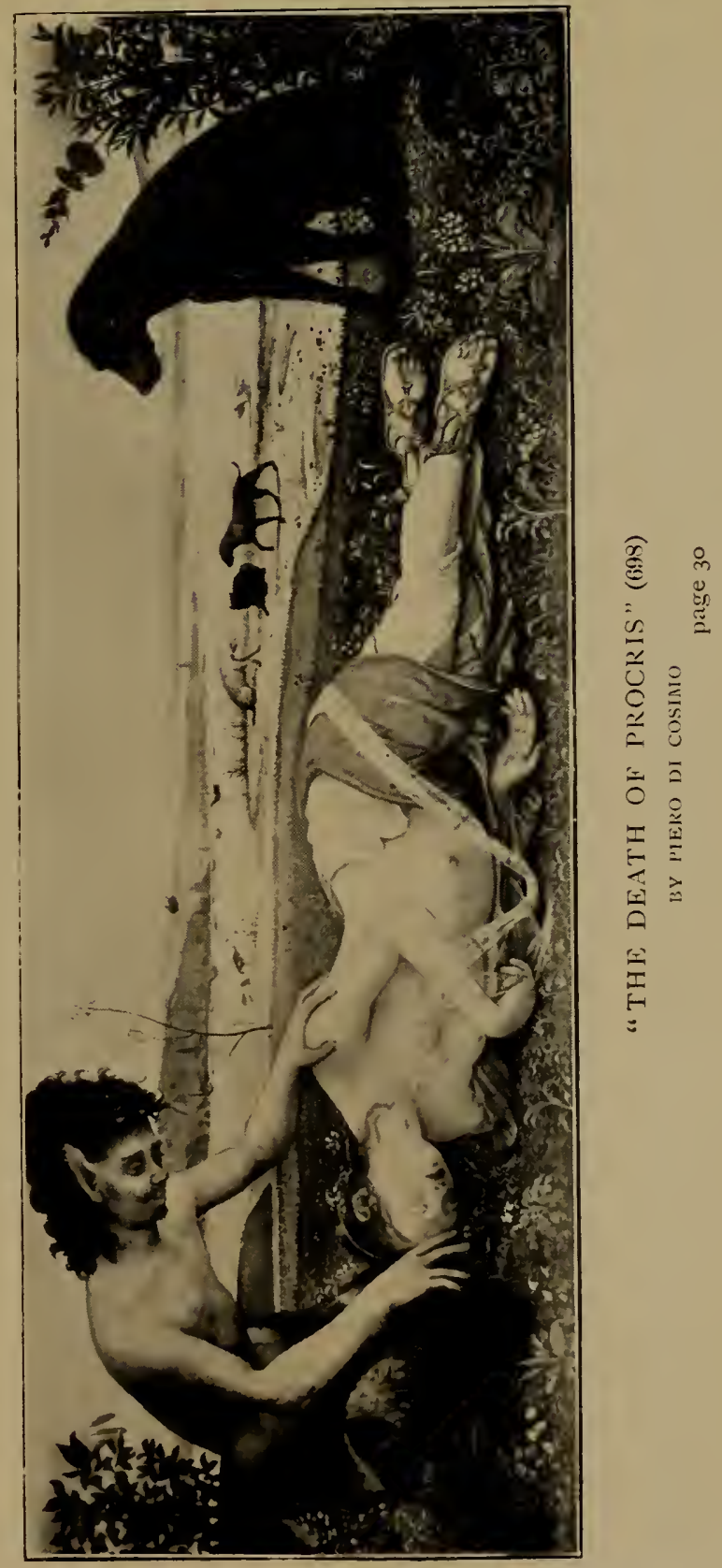



gathered about his tormented soul. A terrible misfortune overtook him in his old age; he was struck with paralysis, and Vasari tells us of his misery, how he would try to keep his hands steady, how he would force himself to hold a maul stick and brushes, but it was all in vain; his grasp grew feebler, and things would drop from his fingers. Then he would rage, and, in his despair, he would talk wildly. It was very pitiful to watch him, but peace came at last, and one morning the grim old man was found lying dead at the foot of his stairs.

"The Death of Procris" is a beautiful picture. See how charming is the wide effect of light in the sky; how charming also are the flowers in the foreground. All the tenderness underlying Cosimo's rough exterior is apparent here. We must think of that picture painted in the untidy studio by the solitary artist. Do you know the story of Procris ? She was a nymph ; she ran, oh! so lightly, she was glad and free, and she fell in love with Cephalus, the young huntsman; she loved him so much that she was jealous of whoso approached him. She made herself miserable fancying that Cephalus loved another nymph. One day, when he was gone hunting, she followed him secretly and hid behind a bush, and there she heard his voice. He was only saying, "Oh air, how sweet thou art," or something of that kind, but she was sure he was addressing another nymph. She shivered with pain; she pushed forward to see to whom he was speaking, and the leaves of the bush that hid 
her moved. Cephalus, thinking a wild animal was hiding behind the tree, sent his arrow whizzing in its direction, and the arrow hit Procris and killed her. There you see her lying on the ground with the cruel wound in her throat, a long-eared fawn is gazing wonderingly and sadly down upon her, and her dog Lelaps is watching her. He seems to be saying, "Why is she so still, why do not her nimble feet run as they used?" Poor Procris, poor silly Procris!

You must note how Piero di Cosimo uses gold. He was the son of a goldsmith. See how tenderly he has placed it in Procris' sandals, in her beautiful waving hair. Every bit of this picture is full of charming colour. Over four hundred years have passed since it was painted, and still it is bright as on the day it left Piero di Cosimo's studio, and it is quaint, as were its painter's imaginings.

"Raphael and Tobias" (78I), by Antonio Pollajuolo (I429-I498), is a delightful picture worthy to be studied. Some say it is by another person than by Antonio Pollajuolo, that it is by one of his school, and they give good reasons for their opinion. Anyhow it is a very fine example of the early Florentine school. Have you ever read the story of Tobias, the son of Tobit, in the Apocrypha? It tells how Tobit was a Jewish exile, and how he became blind and prayed for death. His son Tobias was to wed a rich kinswoman, Sarah by name, but she was haunted by an evil spirit, who had slain her seven husbands on their wedding night. To the household of Tobit 
came the angel of duty, Raphael, disguised as a menial. He left high heaven and came down in order to watch over Tobias. The time came when the youth must go forth to marry Sarah, and the angel went with him. We see them in the picture journeying together over the green country through which winds a river. The angel and the lad are conversing together, and, as they converse, they walk fast. The dust rises under their speeding feet. Tobias, like a young bridegroom, is hastening to see his love, and Raphael is his protector and adviser. Tobias's dog goes before them-a grey, fluffy dog careering in front. The angel carries a small box, intended for gall, wherewith to cure Tobit of his blindness, and Tobias carries a fish, the heart and liver of which, pounded together, is to act like a charm and drive away the evil spirit that haunts his bride. Raphael's wings are strong and sheeny pinions. The rapidity of his walk sends his garment in serried folds around his figure; his charming face is smiling down upon Tobias, who, dressed in fifteenth-century costume, is eagerly looking up. You must note the landscape background, which is very fresh and pleasant.

To Antonio Pollajuolo is ascribed the "Martyrdom of St. Sebastian" (292). Look at the wonderful drawing of that picture. The martyred saint stands pierced by many arrows, . and all about are the executioners. Some are in the act of shooting, others are changing their cross-bows. One in the foreground is a perfect masterpiece of drawing. Pollajuolo was the first 
to study artistic anatomy-that is, the play of bones and muscles under the flesh. He was the first to dissect dead bodies for that purpose. Uccello, we have seen, established the rules of perspective, and here we find anatomy entering into the curriculum of the painter. This picture of St. Sebastian is a marvellous presentation of the human figure. The painter was celebrated as a sculptor in bronze, and he was famed for modelling. Yet the picture is lacking in what we find so pathetic in earlier pictures, where the genius of the painter is concentrated upon rendering the expression of the face, the divine look of prayer and exaltation. This St. Sebastian is a magnificently modelled figure, and all about him stand figures as nobly executed. And yet we look upon the cruel scene unmoved, it seems to me that the emotions of pity and repulsion are not conveyed by the artist.

The glory of Domenico Ghirlandajo (I449-I494) is to have been the master of Michael Angelo. He was accounted the greatest teacher in Italy, and to him for instruction went this genius of the Florentine school. Domenico Ghirlandajo's work is very fine and true; and his fame rests upon portraiture. In all his pictures you will see painted the faces of his contemporaries - the men and women of his time. For a century after Giotto there was but one conventional facial expression. Every face was like another face. Then, very humbly, religious painters began to introduce into their work the portraits of the giver of the picture. 
Ghirlandajo developed this practice. He differentiated the countenances of the individuals, and under him the portrait became an independent branch of art. We have two portraits by him-(I230) that of a young girl in a red bodice; her face is characteristic, framed in by her long waving hair; the other (I299) is the portrait of a youth.

His son, Ridolpho ( $1483-156 \mathrm{r}$ ), excelled also in portrait painting. $\mathrm{He}$ was a great friend of Raphael, who invited him to Rome to paint with him. But Ridolpho refused the invitation and remained in Florence, his native city, surrounded by friends and patrons, advancing in his art and in the estimation of other men. He had great ideas of composition, of forcible colouring, but what distinguishes him among his fellows is the earnestness and the character of the heads he painted. The "Procession to Calvary" (II43) is full of movement, full of character, and also full of pathos. The Saviour is wearily bearing His cross, followed by a company of soldiers and accompanied by a procession of weeping women. St. Veronica is among them, and she, her heart full of pity for the suffering Saviour, wipes with a napkin His brow, all bedewed with drops of agony. When the Saviour returns the napkin to her, lo ! it bears a miraculous imprint of His features. It is a fine picture, full of a mystic spirit, notwithstanding thebrightness of its colouring and the atmosphere surrounding the figures. In the crowd Ridolpho has painted many portraits, among others those of his father, Domenico, and of several friends. 


\section{CHAPTER V}

\section{MICHAEL ANGELO (1475-I 564)}

"The fetters of my tongue do Thou unbind That I may have the power to sing of Thee, And sound Thy praises everlastingly:"

WORDSWORTH (From the Italian of Michael Angelo).

"The Entombment of our Lord" (790). We come now to an artist who was the crown and glory of his age, and of his school, as he was the crown and glory of the art of all time. You have all heard of Michael Angelo. Ruskin says that his imaginative perception was almost superhuman. If you go to Rome you will visit the Sixtine Chapel, the ceiling of which he painted. Saints, sibyls, prophets are there. The story of the creation of man, of his fall and of his redemption, is the theme presented there. Over the altar he painted that greatest of all visions seen by the inner eye of man-the Last Judgment.

It would be impossible for me to sketch here Michael Angelo's life, or to give you an idea of his greatness. He was the son of Lodovico di Leonardo Buonarotti Simoni, a descendant, it is said, of the Counts of Canossa. His father had a small estate close to Florence, and that estate was rich in quarries of hard stone. "The 
nurse of Michael Angelo," says Vasari, "was a stone-cutter's wife, and she would sometimes put into the baby hands of her little charge a chisel and hammer." . Michael Angelo used to say to Vasari, "Georgio, if I have anything of genius it came to me from being in the subtle air of your country of Arezzo, while from my nurse I got the chisel and hammer with which to fashion my figures."

His father wished to place him in the woollen and silk trade, but the hand of the spirit was upon the boy, and he would spend his time in drawing secretly. There was no resisting the claims of inborn genius, and when Michael Angelo was fourteen his father had ceased to throw obstacles in his way. He placed the boy with Ghirlandajo, who was considered the best teacher in Italy. The master recognised the genius of his pupil.

Lorenzo de' Medici was one of the great nobles of Venice; he had a splendid garden on the Piazza San Marco, the alleys of which were filled with antique sculpture. Lorenzo wished to transform that garden into a school of sculpture. He wrote to Ghirlandajo inviting him if he had a pupil of genius to send the youth to this open-air academy. Michael Angelo was sent, and we must think of him in the fragrant avenues of the beautiful garden handling the marble and the chisel. He was greatly envied by some of his fellow-students, and, in a quarrel with one, he received a heavy blow which fractured his nose. This gave a peculiar look to his rugged countenance-the look of an antique 
bust that has been mutilated. Michael Angelo won the love of Lorenzo de' Medici, and stayed in his house four years, when the death occurred of that great patron of art.

He then left Venice for Florence and went on to Rome, executing on his way a triumphant series of works. I could not enumerate to you all that he did in sculpture and in painting, but here are a few masterpieces-the statues of "David" and "Moses," the wonderful statue of Duke Lorenzo brooding in the shadow of the grave, the four symbolic figures of "Night" and "Day," of "Dawn" and "Twilight" that are so beautiful, Vasari tells us, that "if art were lost they are sufficient to restore it to light." Pope Julius II. had ordered the mausoleum for himself, and he resolved to rebuild the church of St. Peter in order to give Michael Angelo's work a fair setting. Thus he became the architect of the great cathedral of St. Peter's at Rome.

Michael Angelo was a solitary man, a patriot and a poet in marble, in painting and in words. Raphael, of the "sweet Madonnas," used to say that he thanked God to have been born in the days of Michael Angelo. In his old age the incomparable artist loved the beautiful Vittoria Colonna, the widow of the Marquis of Pescara. He wrote sonnets to her and she wrote some to him. Religious sympathy united them. In his youth Michael Angelo had heard Savonarola preach, and he and Vittoria were the monk's disciples, for both believed in the internal reform of the Church such as Savonarola preached. She died, and the old man watched by 
her bedside; and, when the last sigh had left her lips, he kissed the dead hands, afterwards bitterly regretting that he had not kissed her forehead and cheek. Beautiful and sacred friendship worthy of two such peerless souls! He died many years after, but he preserved to the last the memory of what she had been. Our poet Wordsworth has translated some of Michael Angelo's sonnets. In one addressed to Vittoria he says-

"Better plea,

Love cannot have, than that in loving thee

Glory to that eternal Peace is paid,

Who such divinity to thee imparts

As hallows and makes pure all gentle hearts."

This picture of "The Entombment" is quite unfinished. Perhaps it was painted in early youth and laid aside. There is grandeur in the conception, but it fails to hold us by the subtle charm of presentation. There are the three Marys. The kneeling Virgin is vaguely outlined; just in front of her is Mary, the wife of Cleophas, a figure that has in it a touch of woeful grace. The other Mary, a tall, slight woman, helps to hold the twisted sheet in which Christ is being carried. Salome is also there, seated on the ground examining something in her hand which has not been rendered by the artist. Joseph and another in the background support the Saviour, whose figure is painful to look at in its emaciation. The picturein its unfinished state is valuable to students, for it reveals Michael Angelo's method of work.

"The Madonna and Infant Christ: St. John 
the Baptist and Angels" (809). This picture is unfinished also, but the charm and majesty of the work are manifest. There is in it a haunting mystery. The Madonna, a beautiful figure, holds an open book out of reach of the Child, who is trying to grasp it. That book contains the scroll on which the sorrows He has to meet are recorded. St. John the Baptist, hiding his sad little countenance, stands near her. Behind are two wingless angels reading from another scroll. On the other side of the Virgin and behind her are two unfinished angels with shrouded heads. Mark the beauty of the Virgin's expression, the simple treatment of the folds of her dress, the nobility of her attitude. From these two pictures you must try to guess the greatness of Michael Angelo's genius -a genius expressive of that of Florence, of its intellect, its unresting quality, its religion. You must always remember that to understand a picture you must try to feel it through the artist's temperament; you must try to understand the ideals of the age in which it was painted; above all, you must understand its religion. It is Michael Angelo's spiritual power that still lives on for us in these works, however unfinished they may be, and gives to them an arresting quality. 


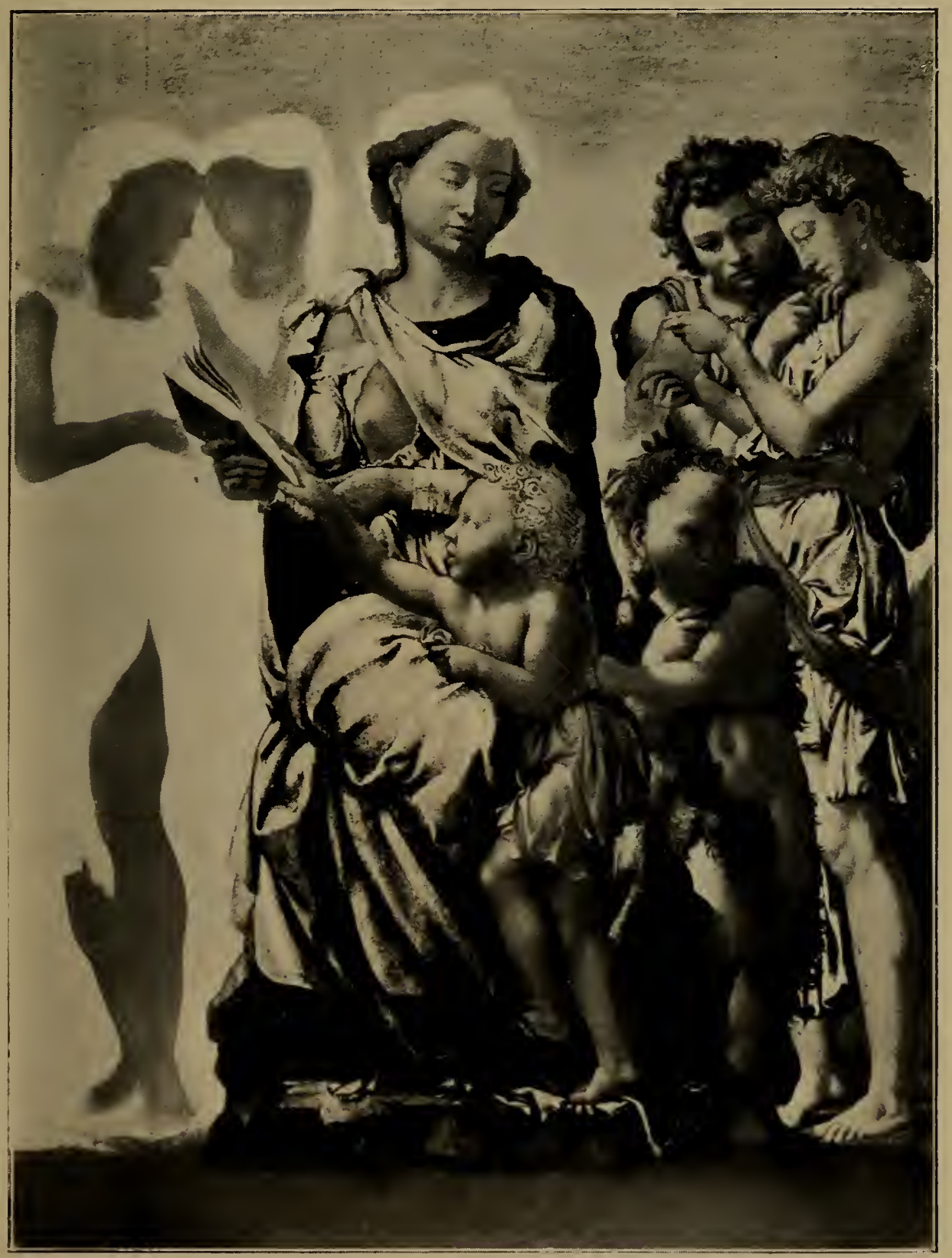

"THE MADONNA AND INFANT CHRIST, ST. JOHN THE BAPTIST, AND ANGELS" (809)

BY MCIELANGELO BUONARROTI 



\section{CHAPTER VI \\ LEONARDO DA. VINCI \\ "Blessed babe! what glorious features, Spotless fair, divinely bright, Must $\mathrm{He}$ dwell with brutal creatures? \\ How could angels bear the sight."}

I sHALL take you at once to Room IV. to stand before Leonardo da Vinci's picture, "Our Lady of the Rocks" (1093). Its almost unearthly effect is produced by the light being concentrated upon the faces of the mother, the children, the angel ; all the surroundings are lost in shadow.

Leonardo (I452-I5I9) represented the eager spirit of the Renaissance. He had the intellectual restlessness of the Florentines. He was a painter, a poet, a sculptor, a musician, an architect, a machinist, a mathematician, a philosopher and an explorer. He wrote upon art, he practised anatomy upon dead bodies, he understood perspective, and he excelled in the new science-the management of light and shade. Vasari tells us of his great personal beauty - "the radiance of his countenance," he says, "brought cheerfulness to the heart of the most melancholy." He relates stories of the tenderness of Leonardo's heart, so that "while passing by a place where they sold 
birds, he would take them out of their cages and, paying the price that was asked for them, he would let them fly into the air, restoring to them their lost liberty."

This picture is one of the great pictures of the world. In a flowery nook, guarded all round by weird-looking rocks, like fangs (they are the least good thing in the picture, for Leonardo was not much attracted to landscape painting), the Virgin is kneeling, her arm round the little John the Baptist, who holds his cross of reeds, whilst an angel supports the child Christ. The divine little One, with hand upraised, blesses his cousin who is kneeling before Him. It is a charming scene, reposeful to the mind and to the heart. The light touches the child Christ, creeps up to the face of the angel, falls upon the beautiful motherly countenance of the Virgin, and seems to die away upon the form of John the Baptist. The faces of the mother and the angel are both illuminated by that inner smile of peace that distinguishes all the women's faces painted by Leonardo. It is the Leonardo smile touching the lips, reflected in the eyes, setting the dimples playing on the cheeks, but not widening the lips. It tells of a heart at peace, of a joy that is rooted in the soul. It is a smile that suggests listening to music-the music of sweet thoughts. Look and look again at this picture, and each time you will find in it some new beauties-all but the rocks, strange basaltic formations that are not natural, and yet that seem to harmonise with the aspect of the 


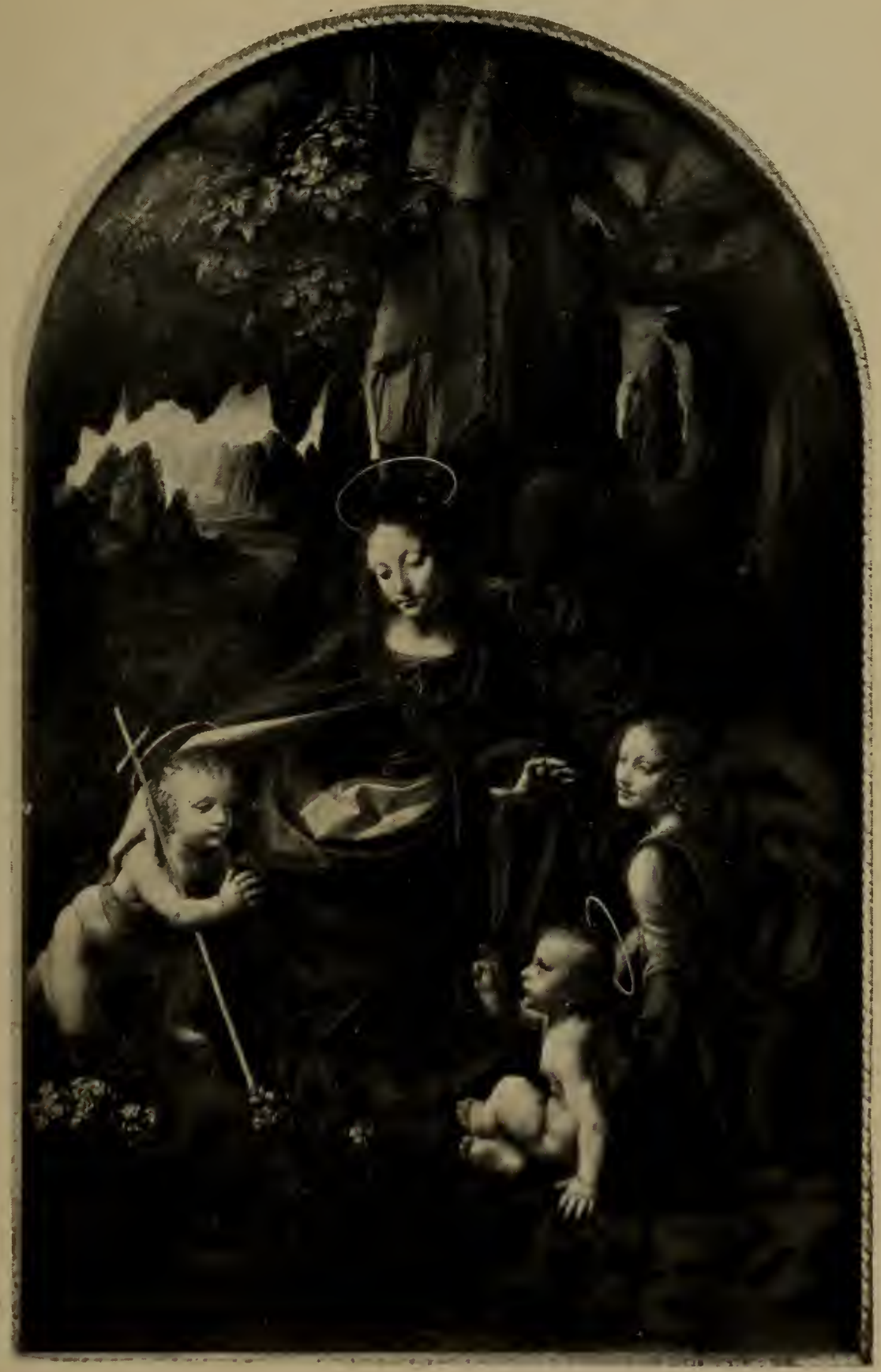

"THE VIRGIN OF THE ROCKS" (L093) BY L.EONARDO DA VINCI 

scene. Leonardo da Vinci died at over seventy years of age, and he died in the arms of King Francis the First of France.

Later I shall speak to you of Raphael, but I want you always to remember these three great names, those of this trinity of genius, unapproachable, mysterious. Michael Angelo representing strength; Leonardo da Vinci, whose subtle charm is not to be analysed, but whose mysterious appeal it is impossible to resist; Raphael, the exponent of a grace human and divine. The art of these three must exist so long as there are pictures in the world. Michael Angelo, Leonardo da Vinci, Raphael, the perfect three in whom culminated the genius of art. The Florentine school declined and faded away after the death of Michael Angelo and Leonardo da Vinci. All that came before pointed to them, all that came after declined from them.

There are many pictures that I have not noticed, for I want simply to be a guide to the greatest works, the most memorable ones. Later you will come to enjoy and to know all the pictures on these walls. 


\section{CHAPTER VII}

\section{ANDREA DEL SARTO AND OTHERS}

"God and the glory! never care for gain. The present by the future what is that? Live for fame, side by side with Angelo ! Raphael is waiting : up to God all three."

Opposite Michael Angelo's work is a portrait long reputed to be the likeness of Andrea del Sarto, called the "faultless" painter. It is that of a beautiful and sensitive face-the face of a true artist. Look at the brown eyes as they gaze appealingly out of the canvas. Look at the sensitive mouth, at the delicate chin that bears the fatal mark of weakness. The face fits in so well with our idea of the artist, that we would fain believe it to be that of Andrea del Sarto. Its melancholy seems to betoken a soul clouded by a sad memory.

Andrea del Sarto (I486-r53I) carried about with him a consuming remorse and sorrow. What a contrast there is between Michael Angelo's rugged countenance and the melancholy charm of this man's features. A beautiful face, it was said, had the power to lead Michael Angelo's soul to heaven, as that of Beatrice led Dante's up to the mysteries of the white rose of Paradise. A beautiful face 
had the power to drag down Andrea del Sarto to depths of dishonour. He was married to a lovely woman named Lucrezia, and he loved her passionately. She was always needing money to buy jewels, to spend on pleasures, and he never could refuse her. "He was of a soft and pliable disposition where honour was concerned," says Vasari, the genial gossip, and we can understand this verdict as we look at this appealing face long held to be that of Andrea del Sarto.

King Francis the First of France had seen two pictures by the "faultless painter" which he greatly admired, and he commissioned Andrea to ornament one of his palaces. Andrea went, miserable at leaving his wife, still full of high hopes for the future. He was received by the King of France with magnificent hospitality. $\mathrm{He}$ set to work, and his work was appreciated by the monarch and his courtiers. All was going well with him, but for Lucrezia's letters. She was weary of waiting; she entreated him to come back; at last she said he would find her dead if he did not return. Andrea asked the King's permission to leave for a time, promising to return with his wife, swearing on the Bible that he would come back. Francis allowed him to depart with regret, and gave him large sums of money in payment for future toil and for the purchase of works of art. Andrea. hurried back to Lucrezia, but he never returned. He spent the money that had been given him in buying jewels for her, in building her a beautiful house. He never went back to finish the pictures 
he had been commissioned to paint; he never purchased the works of art he had been entrusted by the king to buy. He broke his troth; he squandered money that did not belong to him. That is the great stain on his character.

He was a pupil of Piero di Cosimo, and a friend of the great painter Francia. Opposite to the portrait long believed to be his, on the other side of the door, is a "Holy Family" (I 7 ) by him. Lucrezia was his model, and she sat for the Virgin. It is a pretty domestic scene; St. Elisabeth, with her infant son St. John, has come to visit the Madonna and infant Christ. The symbolic cross of John the Baptist, the faint circle of gold round the Virgin's head, alone testify to the divinity of the scene. It is difficult to believe that the soft lips painted here were addicted to violent words as Lucrezia's are reported to have been, that the brow so lofty and pure belonged to one who was a seductress, winning her husband away from the straight path, leading him into another path whose end was destruction.

Look out for the works of Andrea del Sarto in other galleries; you will always recognise them by the softness of their outline, by the rounded curves he loved to paint, by the subtle gradations of the light and shade-by their cool sweet colour. Andrea died in I53I when he was forty-five years of age, of the plague, and Lucrezia survived him forty years.

Before we leave this room I want you to glance at Lorenzo di Credi's "Virgin Adoring" (648) 
and the "Virgin and Child" (593). These pictures are full of fervid and poetic fancy. In "The Virgin Adoring the Infant Christ" the scene is the corner of an old-world city. See the pretty background, the river winding through wooded banks crowned by a formal garden. We can imagine di Credi walking down that zigzag path. It is not Bethlelem but Italy he has painted. It is the garden he loved, the familiar corner of the river he had looked upon so often. The sweet and gracious Virgin is kneeling before her Babe; the light of mother love is on her face, and something of the awe of the spirit before its God is also upon it.

"Sleep, sleep, mine Holy One!

My flesh, my Lord! what name? I do not know

A name that seemeth not too high or low,

Too far from me or Heaven."

Lorenzo di Credi lived in troublous times (I459I537) but he kept his faith unsullied. He was a disciple of Savonarola, and he took part in the great sacrifice, when men and women threw into the fire lit at the door of the Cathedral their most precious treasures. How delicate is the painting of these pictures, how painstaking it is in all its details. Look at the veil over the Virgin's head, at the exquisiteness of the flowers growing near the Child.

Here is a lovely picture by Fra Bartolommeo (I475-I5I7), entitled "The Virgin and Child with St. John" (I694). The Virgin is seated on the ground out in the open air, behind her is the river 
on the shores of which grow some feathery trees; a distant town and blue mountains are beyond. It is a charming and peaceful landscape. She is seen in profile with her left hand supporting the head of the little John the Baptist, pressing it towards the Child who is leaping forward to embrace His cousin. We might imagine just such a scene on a sunshiny day hundreds of years ago, -a young Italian mother, graceful with the unconscious grace of nature, her baby at her knee, and the painter sketching her.

Bartolommeo was a disciple of Savonarola and he, too, had taken part in the great sacrifice. $\mathrm{He}$ was a painter then, and his thoughts had not yet turned towards the holy life. The preaching of Savonarola moved his heart, and Vasari tells us that when the monk was condemned to death Bartolommeo took the vows and joined the order of the Dominicans. He died at the age of forty-two. 


\section{CHAPTER VIII}

MOSTLY ABOUT THE SCHOOL OF SIENA

"Yon heaven thy home, that waits and opes its door."

Now let us pass on to Room II., which is devoted to the Sienese school. Siena was close to Florence as we now compute distance, but in those days, when the difficulties of travel were great, the schools did not touch each other. That of Siena was extremely religious. Its Guild of painters, in their charter, proclaimed religion to be the one saving influence in life and art. "Since we are teachers to unlearned men, who know not how to read, of the marvels done by the power and strength of holy religion . . . and since no undertaking, however small, can have a beginning or an end without these three things-that is, without the power to do, without knowledge, and without true love of the work ; and since in God every perfection is eminently united; now, to the end that in this our calling, however unworthy it may be, we may have a good beginning and a good ending in all our works and deeds, we will earnestly ask the aid of the divine grace, and commence by a dedication to the honour of the Name and in the Name of the most Holy Trinity." 
As we look round this room we feel how truly religion inspired the painters. How beautiful is the colour, but how quaint is the drawing. What strikes us as we look at this collection of works of artists of Siena is the quantity of gold they used; they have golden backgrounds, golden halos, the light on the drapery outlined in gold-all is a survival of the Byzantine art that reigned before Cimabue and Giotto brought a new spirit into the world. In its retreat among the mountains Siena felt at first none of the movements that reached Florence. It knew nothing for some time of Uccello's perspective, of Pollajuolo's anatomy; it was moved by the spirit of religion only, the one that first inspired art.

Some judges have considered Matteo di Giovanni (I435-I495) as the school's best and most representative painter; others look upon Duccio (r260I340) as its most conspicuous and important figure. The latter was certainly the Cimabue of the Sienese school. He partly forsook the conventional Byzantine manner, and sought to bring into his pictures some resemblance to nature. To one of his works was accorded the honour that was accorded to Cimabue's Madonna. It was carried through the city to the Duomo of Siena, the church bells rang, the trumpets sounded, as the great picture was taken from the studio, where it had been painted, to the church where it was to hang. It showed the Virgin surrounded by angels seated on a throne, holding in her arms her Babe; angels, with their chins in their hands, looked at 



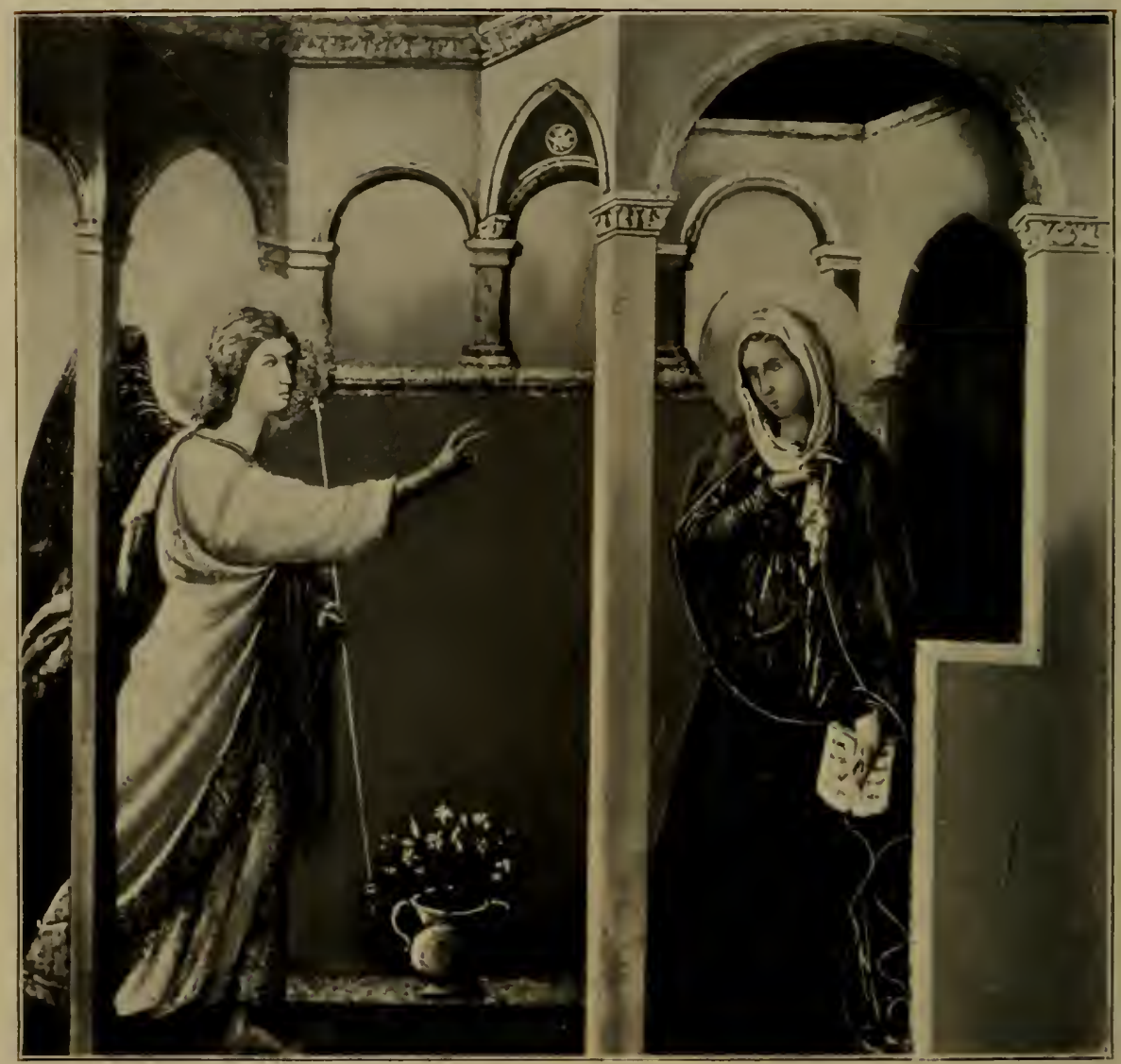

"THE ANNUNCIATION" (1139)

BY 1$)$ CCIO 
her; saints and prophets were kneeling in reverent attitudes before her. The archibishop with his clergy, the fraternity of the monks, the great officials of the commune followed by a crowd of men, women, and children in holiday attire, wound their way through the city. It was a great time for art when the painting of a picture could be thus celebrated. It was a time when there was no reading-when all the ideas of men came to them through things seen.

In "The Madonna and Child" (566) I think that Duccio tried to make men understand the humanity as well as the divinity of Christ. Like a true human child he draws aside the veil that hides His Mother's face. Above are the prophets, below St. Dominic and St. Catherine adoring this vision of the Virgin. There is still a good deal of the Byzantine influence, but we see a new awakening in this art of Duccio.

I want you next to look at "The Assumption of the Virgin" (II55) by Matteo di Giovanni, who lived nearly two hundred years later. That picture resumes all the artist's creed. The Virgin seated on clouds ascends heavenward, cherubim and seraphim float around hailing her. She wears, as does the Beatrice of Dante in Paradise, the three theological colours. Her draperies are white, red, and green, symbolic of faith, hope, and charity. The background is golden. Her empty tomb is below, groups of prophets are on either side. St. Thomas is there pressing forward to grasp the girdle, which legend says the Virgin threw down 
to him as she ascended. Duccio and Matteo di Giovanni, therefore, are the two representative masters of the school of Siena. Duccio at its dawn, Matteo heralding its setting.

There are many artists between them-Ugolino (died about 1339), about whom few authentic details are known, but who, like Duccio, sought to emancipate himself from convention. "The Procession to Calvary" (II89) by him is a series of little scenes from the great tragedy of the Passion. He was in great repute, and a Madonna that he painted was believed to have miraculous powers. There were the two brothers Lorenzetti, who painted pathetic, ill-drawn figures, illustrative of some miraculous incident. Niccolo Buonaccorso (I388), remarkable for his marvellous elaboration of gold ornaments. Then (in $\mathrm{I}_{436}$ to about $\mathrm{I}_{5} \mathrm{I} 7$ ) came Benvenuto da Siena, who knew how to harmonise the old spirit with the new-the old gold background dear to the Sienese to the fresh flesh colouring of little children. In the "Madonna of the White Rose" (909) these attributes are pre-eminent. In the compartments on either side are St. Peter and St. Nicholas of Bari, with his favourite emblem, the three gold balls, at his feet. 


\section{CHAPTER IX}

\section{UMBRIAN SCHOOL}

\section{PERUGINO}

" For all honest work is worship, And to labour is to pray."

THE painters, natives of the townlets round the hamlet of Assisi formed the Umbrian school. There had been born the saint whose heart burned with love and pity for the suffering of men and beasts. Assisi, closely associated with the life of St. Francis, is the spiritual mother of the school of Umbria. Essentially religious in spirit this school had a cultivated sense of classic beauty in the human form, far excelling that of Siena.

To the Umbrian school belongs the glory of having nurtured Raphael-dear Raphael who painted the "Madonna and Child" as no man has painted them. His master, Perugino, belonged to this school. He was born about I446, and died in 1524. His real name was Pietro Vannucci, but, later, when he became a citizen of Perugia, he called himself after the town of his adoption. He was brought up in great poverty. Vasari tells us he was apprenticed to an artist who was very deficient as a painter, but who had a great reverence for art. The master was always telling his pupil what 
a glory it was to excel in painting, and Perugino's imagination was fired. He was continually asking which was the best place to study in, and the master always answered that Florence was the only place, firstly because all men there were critics, secondly because Florence was not built upon a fertile soil, so that all must work hard to gain a living, and, lastly, because the air of Florence excited dullards, so that the dwellers therein for ever sought honour and glory.

To Florence went Perugino eager in his quest. He studied, we are told, under Andrea Verrocchio. and in a few years he had obtained a great reputation, so that his pictures were sought for in many countries besides Italy. He was sensitively honest, and he easily took offence. Once he had to ornament with painting the cloisters of a convent, of which the prior had a great reputation for making ultramarine. This is a most beautiful blue extracted from a very rare and precious mineral. The prior was very suspicious, fearing that his ultramarine should be stolen, so he would watch the artist at work; and honest Perugino took it very ill that the prior should distrust him. He resolved to prove to him how easy it was to cheat, if you were so minded, and, ordering a large pail of water, he continually washed his brush laden with ultramarine. Every time that the prior groaned because he had to provide more of his precious colour, Perugino would say cheerfully, "You see I have used it all." The picture was finished; then the artist took his noble revenge. 
He emptied the water and showed a deposit of blue mineral collected at the bottom of the basin.

"You should not distrust an honest man," he said to the prior. "You must learn to trust, for the honest man too knows how to deceive suspicious men like yourself."

The National Gallery possesses four undoubted pictures by Perugino (I8I, 288, I075, I44I). "The Baptism of Our Lord" (I43I) is not undoubted, so we do not include it in our list. You will find in all these pictures a lovely purity of tone, an ideal sense of beauty, and a most perfect grace. The peacefulness of the landscape, introduced as a background, brings a spiritual repose to the work. In the "Madonna and Child" (288) we see the quiet hills behind the Virgin's head; a lovely river runs at their base, peaceful as a river in Paradise. The somewhat formal trees repeat each other, one on either side; their slender stems, their branchings, are examples of perfect symmetry. It is like a landscape seen in a dream, not quite natural, but full of mystic romance.

If you look at "The Virgin and Child and St. John" (I8I) you will find these qualities repeated. The saintly beauty of the young Virgin's face is very noticeable; there is a melancholy and a purity on her broad brow, in her downcast eyes, gazing with an anticipation of sorrow on her bonny boy. The richness of her raiment is finely rendered; on the border of her mantle, embroidered in gold, is Perugino's name. Behind her head stretches a delicate sky, hills at whose base winds a river, 
level meadows beyond; all are steeped in a transparent golden glow. In the picture (288) which I have mentioned there is the same purity, the same exquisiteness of tone. The young mother is worshipping her Child, which an angel is holding, angels aloft are choiring praises to It, while on either side are two panels; on one is depicted the Archangel Michael, dressed in armour typifying that he is the "orderer of Christian warfare," on the other is Raphael, the ministering angel, the friend of man; Tobias is looking at his gentle countenance. All Perugino's qualities are repeated in "The Virgin and Child, St. Jerome and St. Francis"1 (I075)-beautiful pictures painted by a master hand, seen in a master's vision !

Perugino died at the age of seventy-eight. Vasari tells us that he was very fond of money, because of the extreme poverty of his up-bringing. All his pictures testify to the charm and peace of his soul.

1 "The Adoration of the Shepherds" (1441) is believed to be the last picture by Perugino. 


\section{CHAPTER X}

\section{UMBRIAN SCHOOL (Continued)}

\section{RAPHAEL (1483-I 520)}

"Oh their Raphael of the dear Madonnas!"

LET us now approach the works of Raphael Sanzio. We know that his name stands with those of Michael Angelo and Leonardo da Vinci, and that the three represent grace, strength, and science.

Giovanni Santi (about I440-I494), Raphael's father, was a painter and a poet. The family originally came from Colbordolo, a hill town in Umbria, where it had fine possessions, but it lost them when Malatesta di Rimini made war upon the district and set the town and castle on fire. At that time Giovanni Santi was a boy. At Urbino, where the Santis settled, the father made a fortune. When the time came to choose a profession, Giovanni preferred to prepare himself to be a painter than to follow his father's successful career.

He painted many pictures. Urbino at the time was ruled over by a just and noble prince, Duke Frederigo di Montefeltro, who invited to his court all the men famed in art and literature. Giovanni Santi was a favourite guest. His pictures were somewhat hard, but were marked by much pious 
feeling. He also wrote a long poem, or rather a rhymed chronicle, in praise of Frederigo's virtues, wherein are mentioned the names of the great men his contemporaries. He had married a rich wife, and a son-Raphael was born to him. That Giovanni was much thought of at Urbino may be gathered from the fact of his being selected to be the host of Piero della Francesca, when this illustrious painter came to the city at the invitation of the Brotherhood of Corpus Domini.

Here is one of Giovanni's pictures, "The Madonna and Child" (75I). The mother is watching the child as it sleeps, supporting his head with her right hand. The sleeping infant is lying partly on a cushion placed on a stone parapet. The background shows a rocky landscape with blue distant mountains.

Thus we must imagine the youth of Raphael passed in the midst of a brilliant society, among artists and men of letters gathered in his father's house. It was a gentle training for his noble spirit.

His father taught him drawing, but soon recognised that the boy had a genius far outshining his own. Vasari says that Raphael's artistic education was then entrusted to Perugino; now, however, it is accepted that Raphael's first teacher next to his father was a painter named Timoteo Viti. The boy continued under this artist's care till after his father's death, when he went to Perugia and entered the studio of Perugino. But a warm and life-long friendship existed between 
himself and Viti. $\mathrm{He}$ was just eleven when his father died, three years before he had lost the mother whom he dearly loved.

It is not certain at what time Raphael became Perugino's pupil. He imitated his master's manner so perfectly that it is often impossible to determine whether it was Perugino or Raphael who painted a certain picture. His charming address won for him the love of all, and Perugino often prophesied that his pupil would be a great artist-the greatest of his generation.

The turning-point in the lad's career came when he went to Florence and saw the sketches by Michael Angelo, Signorelli, and Leonardo da Vinci. He had a marvellous capacity for assimilating the genius of other masters. Michael Angelo's work greatly impressed him; the loveliness of expression of Leonardo da Vinci's women fascinated him; the management of light and shade that is so remarkable in this master's work also fired his imagination. Raphael studied from the nude; he learnt anatomy, and he developed the grace that is the crowning quality of his art. His first manner is called the Umbrian manner.

He was not seventeen when he painted the little masterpiece, "The Vision of the Knight" (2I3). The knight is asleep under a laurel tree; on either side of him is a beautiful female figure. One is more austere than the other; she is dressed in purple; she holds out a book and a sword-the emblems of study and conflict ; the other, a charming creature, the very embodiment of youth and 
joy, offers to the sleeper a sprig of myrtle-the white blossom with its evergreen foliage, which in old times was dedicated to Venus the Queen of Love, and which even to this day is a bridal flower. Both these dream-women are calling to the knight, both are saying "Follow me." It is the old, old story of the two influences speaking to the spirit of man. The story of the choice of Hercules, the story that Tennyson sang in "The Two Voices "-

"So heavenly-toned, that in that hour

From out my sullen heart a power

Broke, like the rainbow from the shower,

To feel, altho' no tongue can prove,

That every cloud, that spreads above

And veileth love, itself is love."

This picture belongs to Raphael's first manner, that of Umbria.

Let us look at the "Madonna degli Ansidei" (II7I), thus called because it was painted for the Ansedei family at Perugia. Raphael was not twenty when he painted it. The Virgin is sitting on a throne under a canopy with St. John the Baptist and St. Nicholas of Bari on either side. How charming is the young mother, how mild and loving is her expression as she holds the Babe on her knee and points with her finger to a pictured page. The Child, a chubby little one, looks attentively at what His mother is showing Him; His head is a little inclined forward, His hand is on His chest. It is a picture of human and divine love beautifully combined. The two saints effectively 


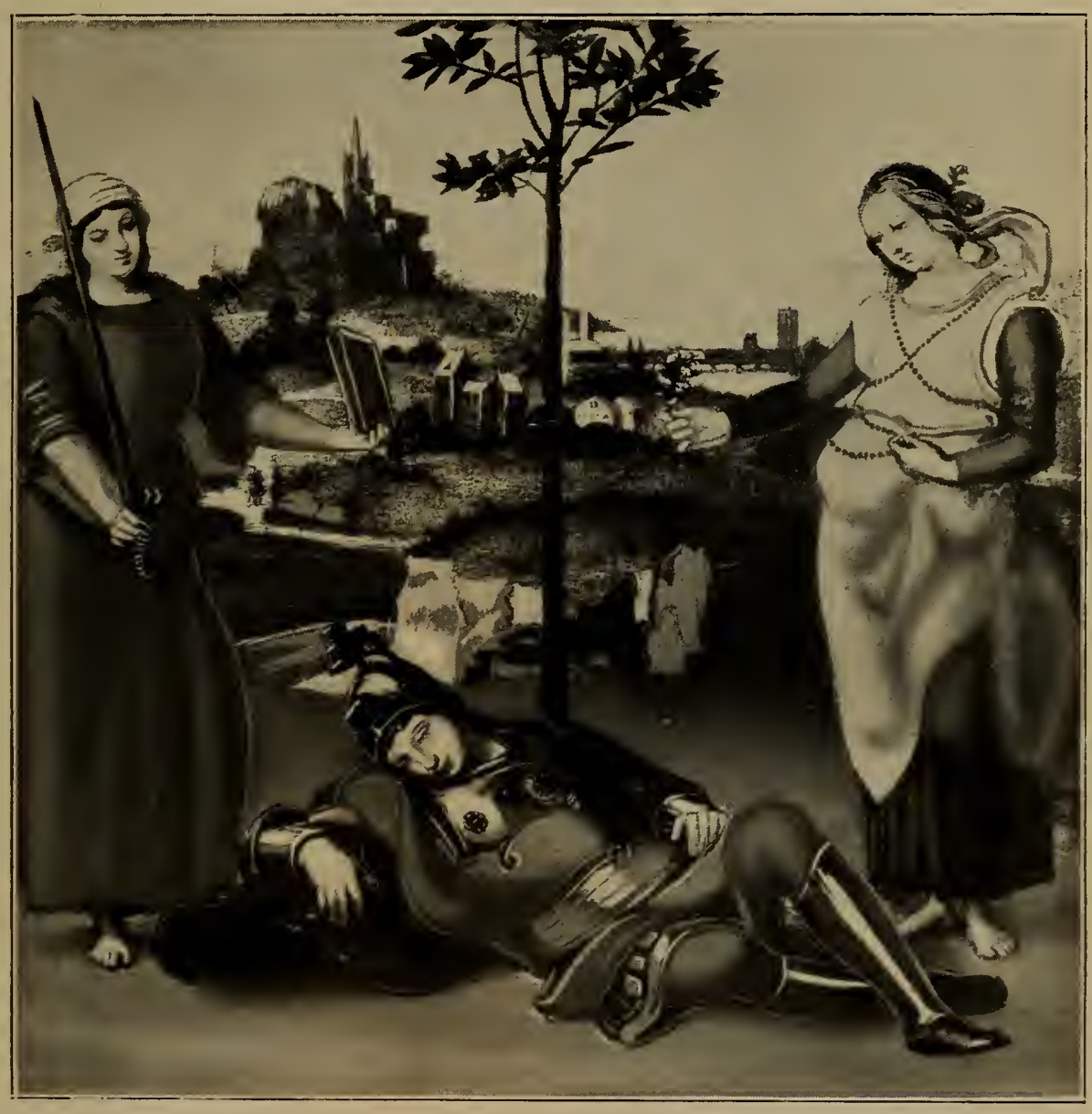

"VISION OF A KNIGHT" (213)

BY RAPHAEL SANZIO

page 60 

complete the composition. On one side John the Baptist, a wild figure, holding in his hand a crystal rod bearing the cross, looks up in rapt ecstasy on the divine Child. On the other side is St. Nicholas of Bari, the scholar saint, absorbed in his book, wearing his bishop's mitre and crook. At his feet are the three purses of gold that tradition says St. Nicholas threw through a window to three dowerless girls.

Then there is the beautiful "St. Catherine of Alexandria "(I68), the princess who loved meditation and study rather than splendour and state, whom the tyrant Maximus slew in his rage. She is no meagre and ascetic saint, but one who belongs to a fine type of developed womanhood. She is leaning on the wheel intended for her martyrdom as she looks up to the sky, through which light is streaming, touching her pure young brow and throat with flame. It was said that the wheel was broken by an angel from heaven, but that Maximus would not be put off making a martyr of St. Catherine, so he had her slain with a sword. See how exquisite is every detail in the picture-the folds of the bodice crossed over her bosom, the wonder of her hands, the charm of the homely landscape behind.

Let us also look at the " Garvagh Madonna" (744). It is a lovely representation of the play of childhood. The Saviour and little St. John the Baptist are making merry together; the mother holds the Child on her lap; He has taken a carnation from the hand of St. John. Look at the pretty gesture of the Child Christ, at the eagerness of St. John the Baptist. Never has children's gaiety been more 
tenderly represented. The Virgin is a stately young mother; behind her is a luminous background of sky and distant open country. "The Madonna of the Tower" (2069) has all the same attributes-the love light on the mother's face, the childlike sweetness of the Babe. His arms are round Mary's neck as $\mathrm{He}$ looks at us out of the picture.

Nor must I forget to mention the portrait of "Pope Julius II." (27), seated in his pontifical chair in his scarlet robes. $\mathrm{He}$ is lost in thought. His passionate spirit is for the moment at rest. This portrait is one of the masterpieces of the world.

I cannot dwell longer on the works of Raphael. $\mathrm{He}$ touched the summit of art; no one has ever gone beyond him in the technique of painting, in charm and tender grace of expression. His pictures are a revelation of the visions genius gives to the artist and of the power that genius gives to his hand. When you go to the South Kensington Museum you should look at his magnificent cartoons. You will see the human figure painted and drawn in a way that has never yet been surpassed. And Raphael himself was as wonderful as were his works. We are told that when he was at the height of his fame no stranger could call to consult him that he did not leave his work to attend to what was needed. $\mathrm{He}$ had the most charming and courteous manners. He presided over a school of some fifty artists, who worked under his influence, and that influence was one of perfect peace. There were no quarrels where Raphael was. 
He was born on a Good Friday, and, when he was thirty-seven years of age, on a Good Friday he died. He was painting "The Transfiguration of Christ," and Vasari tells us that he had put forth all his power to depict the face of the Saviour, It was the last thing he ever did, for there came the call of death. Fever seized him, and he made his will, passing away on the thirty-seventh anniversary of his birthday. "The Transfiguration" was placed at the head of his bier. When the citizens filed in to see the last of the divine painter, the sight of his young inanimate body and of his living work filled them with grief. The room resounded with cries and sobs of lamentation, because Raphael was dead. 


\section{CHAPTER XI \\ UMBRIAN SCHOOL (Continued) \\ "Teach me my God and King \\ In all things Thee to see, And what I do in anything \\ To do it as for Thee."}

WE now come to one of my favourite pictures, "The Nativity" (908), by Piero della Francesca (I4I6-1492). A choir of wingless angels is its chief beauty. The minstrels are singing the praises of the Babe lying on the ground at their feet, accompanying themselves on stringed instruments. Never has singing been represented more beautifully or more realistically. We ask ourselves are they heavenly minstrels or are they mortal maidens singing? Each mouth differs from the other as it utters the words of glory and praise addressed to the divine child. The bodies seem to swing in rhythm to the canticle-

"Answering the stringed noise All their souls in blissful rapture took."

The Virgin is a charming figure kneeling before and adoring her Babe. The landscape is very simple, but what we remember are these delightful songsters half human, half divine. 
Francesca was a pupil of Uccello, the discoverer of perspective. If you look at "The Baptism of Christ in the river Jordan" (665) you will see a foreshortened street in the middle distance that leads up to a fortified town. The street is admirably drawn; it may be a street in Perugia, the city on the hill.

Now look especially at his pupil Luca Signorelli's works (I44I-I523). Famous beyond other painters, the precursor of Michael Angelo, Signorelli was the first who studied "the human form for its own sake." His pictures here are "The Triumph of Chastity" (9I0), "The Circumcision" (II28), "The Nativity" (II33), and each is a masterpiece. In "The Circumcision" especially you must note the splendour of colour, the animation and restraint of the figures, the firmness of the drawing, the harmonious grouping. Look at St. Simon behind the Virgin, at the ecstasy of his expression as he sings, "Lord, now lettest Thou Thy servant depart in peace"; look at the nobility and refinement of the women. Signorelli is best known by his altarpieces, some of which were executed ten years before Michael Angelo had begun to paint the Sistine Chapel. A poet has called him the "morning star of Michael Angelo." Vasari tells us that Signorelli was so devoted to art that when his son died, a lad of seventeen years of age, beautiful in face and form, Signorelli mastered his grief, laid the dead body on a bed, and, seizing his brushes, began to paint. He painted all day, "firm and dry eyed before the lordly 
canvas," until the dead seemed to have come to life. Vasari gives us a glimpse of Signorelli in his old age kindly and courteous. He stayed at Arezzo where the Vasaris were. "I was then a little boy of eight years old," he says, "and I remember how the good old man, who was very courteous and gracious, having heard from the master who gave me my first instruction that I attended to nothing at school but drawing figuresI remember how he turned to Antonio my father and said, 'Antonio, let Georgio learn to draw by all means, for even if later he takes to literature drawing will still be of use and honour and profit to him as it is to all men.' Then, turning to me, as I was standing in front of him, he said, 'Study, little kinsman." "Signorelli ended his days at Cortona, where, says Vasari, he lived splendidlymore like a grand signor than a painter. He died in 1523 .

Let us now look at some of the remaining pictures of the Umbrian school. Here is a picture in three panels, "The Story of Griselda" (9I2, 9I3, 9I4), which I am sure will interest you. Griselda, called the patient Griselda, is as you know the type and pattern of the woman of the old ideals. The story of the wrongs she endured from her husband, the recompense she won at last by being restored to his favour, is told in these panels. I must admit that the patience of Griselda strikes me as anything but praiseworthy. In the first panel we see her in her home. She is a rustic maid, and the high lord of the district is out hunt- 
ing with a splendid retinue. $\mathrm{He}$ sees her and falls in love with her; he takes her home and has her dressed in brocade and gold; he makes her sit by his side at a great banquet. In the second panel we come to a sad scene. Griselda's two children, a boy and a girl, are being carried off, and she is told that they have perished. The high lord, her husband, has grown tired of her, and without any ado he divorces her and sends her back to her father. Griselda patiently goes, puts on her rustic dress, and returns to guard the flocks. It is interesting to note how the servants seem disgusted by the harsh treatment inflicted on their mistress, whilst two gallants, in curiously twisted attitudes, look on half superciliously, half pityingly. The third panel tells the sequel of the tale. The noble lord has sent for Griselda. She appears wearing her peasant's clothes expecting another lady to preside at the feast, and she is ready to submit to this last indignity. But when Griselda comes she is hailed by her long lost son and daughter. The children had not perished, but had been cared for and had grown up in beauty and learning. All ends happily, and we see Griselda, once more splendidly attired, sitting by her lord and master's side dispensing hospitality. She has won the reward of virtue-his good pleasure. The hall where the feast is given is the hall of one of the great palaces of the Renaissance.

This picture is usually ascribed to Pinturicchio, "the little painter" (I454-I5I3). Some dispute about the authorship exists, however. There is 
so much vivacity in the manner of presenting the story, such a charming naivvete that I incline to believe it is by Pinturicchio. His undoubted works are "St. Catherine of Alexandria with her Attributes" (693), "The Madonna and Child" (703), and "The Return of Ulysses to Penelope" (9II). This last picture illustrates Pinturicchio's wonderful naïvete' of manner. The faithful wife of Ulysses is seated at her loom, on which is placed the tapestry that never gets finished. Four suitors in gay attire have entered the room, and, in the background, we see Ulysses, who has just returned. His big bow and his quiver of arrows are hanging above the head of his faithful wife. Through the open window is seen the ship in which Ulysses was bound to the mast, while the sirens sang to him tempting him to come to them. The palace of Circe is on the island hard by. In this curious picture is shown the manner in which two events were often presented, as happening at the same time. We see here Ulysses passing by the island of the sirens, and his return home.

Pinturicchio's pictures are very quaintly drawn, but the colour is full of charm, and there is a pleasing naivete in the conception. He was very much under the artistic influence of Perugino, and he entered into partnership with him. Vasari tells many stories of Pinturicchio's love of money; among others is that of Pinturicchio's death. He was commissioned to paint "The Birth of the Virgin" for the church of St. Francesco in Siena. The friars gave him a large room and emptied it of 
all furniture except of a chest which they could not move. Pinturicchio made so much ado about this piece of furniture being left that at last the friars made a desperate attempt to move it away. As they pushed and pulled it a plank fell out from the bottom and revealed a hoard of golden sequins; there were at least five hundred. The find was a glorious treasure trove for the poor monks, but, says Vasari, "Pinturicchio was so dismayed at their good fortune that he went home, took to his bed, and died of chagrin." 


\section{CHAPTER XII}

THE FERRARESE AND BOLOGNESE SCHOOL

"Let us be content in work

To do the thing we can, and not presume

To fret because it's little."

THE Ferrarese and Bolognese schools are almost one and the same, for the Bolognese school is but an offshoot of that of Ferrara. They are specially interesting for their influence upon other schools. The Ferrarese people had much innate genius for art ; they had also strong originality of character.

Cosimo Tura (I420-I498) is the first painter that we can trace of that school. The great house of Este was the royal house of Ferrara; its lords were among the most learned in Italy, and attracted great men to their service. Piero della Francesca came thither. He was a man of science as well as of art, accomplished in the treatment of light and shadow as well as of perspective. $\mathrm{He}$ it was who influenced the art of Cosimo Tura, who is considered the leader of the school. To the court of Este also came Roger Van der Weyden, a German artist of eminence, who likewise influenced Tura.

"The Madonna and Child Enthroned" (772). Its wealth of detail is extraordinary, the painting 
is brilliant and somewhat harsh in effect. The types of the faces of the angels are certainly Flemish. It has been said that the picture looks like a colcured Flemish window of the fifteenth century. The details are strong and splendid. Six angels play musical instruments; they are sweet, highspirited girls, somewhat German in type and German by their golden hair. They play the viol and violin, and two of them in the foreground play upon a portable organ; one strikes the keys -beautiful ivory keys-while the other blows the bellows. It is an animated scene full of youth and exuberant vitality. We feel that Cosimo Tura was an original genius. Let us look at "St. Jerome in the Desert" (773). There is in the picture the same spirit of vigorous life. St. Jerome is beating his breast with a large stone; all about him is rugged nature, softened into friendliness by the gentle company of birds and beasts who recognise the grim saint to be their friend. Among them is the familiar lion placidly walking to the stream for water. It is a wild and homely scene.

Ercole di Giulio Cesare Grandi (died I53I) is another remarkable painter of the Ferrarese school. "The Virgin and Child with St. John and St. William " (IIIg) is a splendid work. Not much of a personal kind is known about Ercole Grandi, yet we seem to know him as we look at this fine picture. The Virgin is sitting under a rich canopy, a graceful, serious, dark-eyed woman; she holds her Son on her left knee, and $\mathrm{He}$ is beautifully poised. Look how natural is the gesture of His hand out- 
stretched, blessing the spectators and saints. He has a charming face full of benign and childlike grace. Below are the saints. To the left of the throne is the gaunt figure of the Baptist holding a volume. It is the book of Prophets, and, in the other hand, he carries his cross of reeds. To the right of the throne is St. William, a youthful knight, the defender of the faith. Bare-headed. with long flowing hair, he is dressed in armour, his right hand on his sword. $\mathrm{He}$ is a gallant youth, ready to do and die if need be for the faith. He contrasts in appearance with the strange, wild, ecstatic figure of the Baptist. I should like you to examine all the delicate details that adorn this picture, every "one of which has a meaning carefully thought out and placed there with intention by the painter. First of all, on the arch above the Virgin's head, is a beautiful design of angels and lilies. They seem to indicate the painter's love of the Mother of God, whom the holy cherubim and seraphim worship; clusters of lilies between each group signify her purity. Underneath her feet, round the throne, is a design of dolphins that symbolise love, and below them another design of stags and swans-emblems of the heart longing for its God. And still further below is a central panel placed in the base of the throne; it is in ivory and alto relievo; it represents Adam and Eve on each side of the tree of knowledge. On the prædella are scenes from the divine story. We might study this picture for a long time-there is in it so much of symbolism and of simple human nature. 
All the pictures in this room are interesting; those especially by Garofalo (I48I-I559), who has been called the "miniature Raphael." He was afflicted with blindness towards the end of his life, but he was cheerful, and accepted the sorrow as the will of God. I would ask you to look at all his pictures, but particularly at "The Madonna and Child Enthroned" (67I), in which he introduces St. William, the patron saint of Ferrara. We have seen the saint in Ercole's great picture, and St. William appears again here dressed in armour, typifying that he was a soldier and that he had led a soldier's wild life. But his heart was touched, and he left behind the temptations and the glory of the life of arms and became a holy man. He left the weapons of the flesh and adopted those of prayer and penitence. He dwelt in mountain solitudes, communing with his Lord the Christ. Beside him stands St. Clare, who was the friend of St. Francis of Assisi, and who spent her days after the death of this saint in striving with Popes to attain for herself and her order, the little Clares, the triumph of "holy poverty." On the other side of the throne stands St. Francis and the good St. Anthony. All these figures reveal the painter's aspiration after a life which was at one with the divine ideal. St. Francis represented the all-consuming love of created things, St. Anthony the struggle of life with temptation, St. William the bright spirit of man tamed and devoted to the love of Christ, and St. Clare the woman's love for her friend, carrying out his 
work for the poor and afflicted. The whole picture reveals a genius serene and absorbed in divine contemplation. Look also at the "Vision of St. Augustine " (8I), at the "Holy Family" (I70), at "Christ's Agony in the Garden" (642)-we see in all the spirit triumphant over earthly impediments.

One picture by Francesco del Cossa (died I430), whose work in continental galleries you may get to know later, is well worth looking at, "St. Hyacinth Dominican" (597). The figure of the saint is standing upon a hexagonal platform; he is looking up to Christ in glory surrounded by angels, and pointing to a rosary. It has a grandeur and severity which are ever noticeable in this painter's works.

Then we come to Lorenzo Costa (I460-I535), a friend of Francia, whom he influenced to take up painting. There is a certain feebleness in Costa's style, but there is in it a gentle dignity that redeems its shortcomings. He did not paint drapery very intelligently, for it hides rather than clothes the form, and there is a want of balance in his figures; they do not always stand firmly on their feet. He studied landscape and introduced it as a background. It is the purist landscape that he paints, with feathery trees and limpid skies. He has a great sense of colour, and his pictures are full of religious charm. He influenced many painters, who became his scholars, and, to his honour be it said, that he kindled in all a love of art. "The Madonna and Christ Enthroned with Angels" (629) is a very fair example of his qualities and 
THE FERRARESE AND BOLOGNESE SCHOOL 75 also of his limitations. It is a large work in five panels. The Madonna sits enthroned on a high pedestal holding the infant Christ on her knee, angeis on either side bend forward in adoration, and two baby angels play on musical instruments. In the lower compartment are the full-length figures of St. John the Evangelist and St. Peter. Above them are half-length figures of St. Philip and St. John the Evangelist. I am sure you will notice how very limited is the choice of subjects in these painters-the Virgin enthroned, the Virgin and Child, and angels are always appearing.

Francia is the crown and glory of the school of Ferrara. His real name is Raibolini, and he was the son of a carpenter. Born in 1450 , he died in I5I8. Apprenticed in his youth to a goldsmith, he became skilled in all the arts that are required for the handling of the precious metal. He understood enamelling, medal engraving, die sinking, and he became master of the mint of Bologna, and he retained that position to the end of his days, even when painting had become the absorbing occupation of his life. He had, as I have told you, a great friendship for Lorenzo Costa, and, when he -was forty, it was through Costa's influence that he took to painting. Here are two noble pictures that together form one altarpiece- "A Pietà " (I80), in the shape of a lunette, to be placed above (I79), a tall picture showing the "Virgin and Child and St. Anne Enthroned, surrounded by Saints." In the "Pietà" the dead Christ is lying across His Mother's knee, an angel on either side. Oh! how 
sad is the Mother's face, how tear reddened are her eyes as she gazes on the Son so cruelly martyred. He is beautiful in His young manhood; His gentle, refined face shows the trace of His suffering and of His longing to redeem humanity. It is very calm, as if He were sleeping, now that the struggle is over; a faint aureole shows above His head. One of the kneeling angels holds a lock of His red gold hair, gazing out of the picture as if she were saying, "Look how beautiful it is! Oh the pity of it!" And the other angel is gazing at the nail prints in the Saviour's feet. It is a picture filled with the spirit of grief. "The pity of it, oh the pity of it!" is what the weeping Virgin seems to be saying, and it is repeated by the angels watching the recumbent figure of the slain Christ.

In the other picture (I79) we see the Virgin, in her young and happy motherhood, holding her Baby on her lap. He is full of happy infant life as he strains towards the peach held out to him by St. Anne, who is seated by the Virgin's side. She is a noble figure with her shrouded head, the dark veil reaching down to her shoulders, white draperies folded about her neck; she is an austere and gracious type of elderly womanhood. About the Virgin's throne are a group of saints and martyrs-St. Sebastian pierced with arrows, St. Paul leaning on the sword that is to kill him, St. Lawrence bearing the gridiron and the palm of martyrdom, and St. Frediano placed there in honour of the church under his patronage, for which the picture was painted. All are looking 


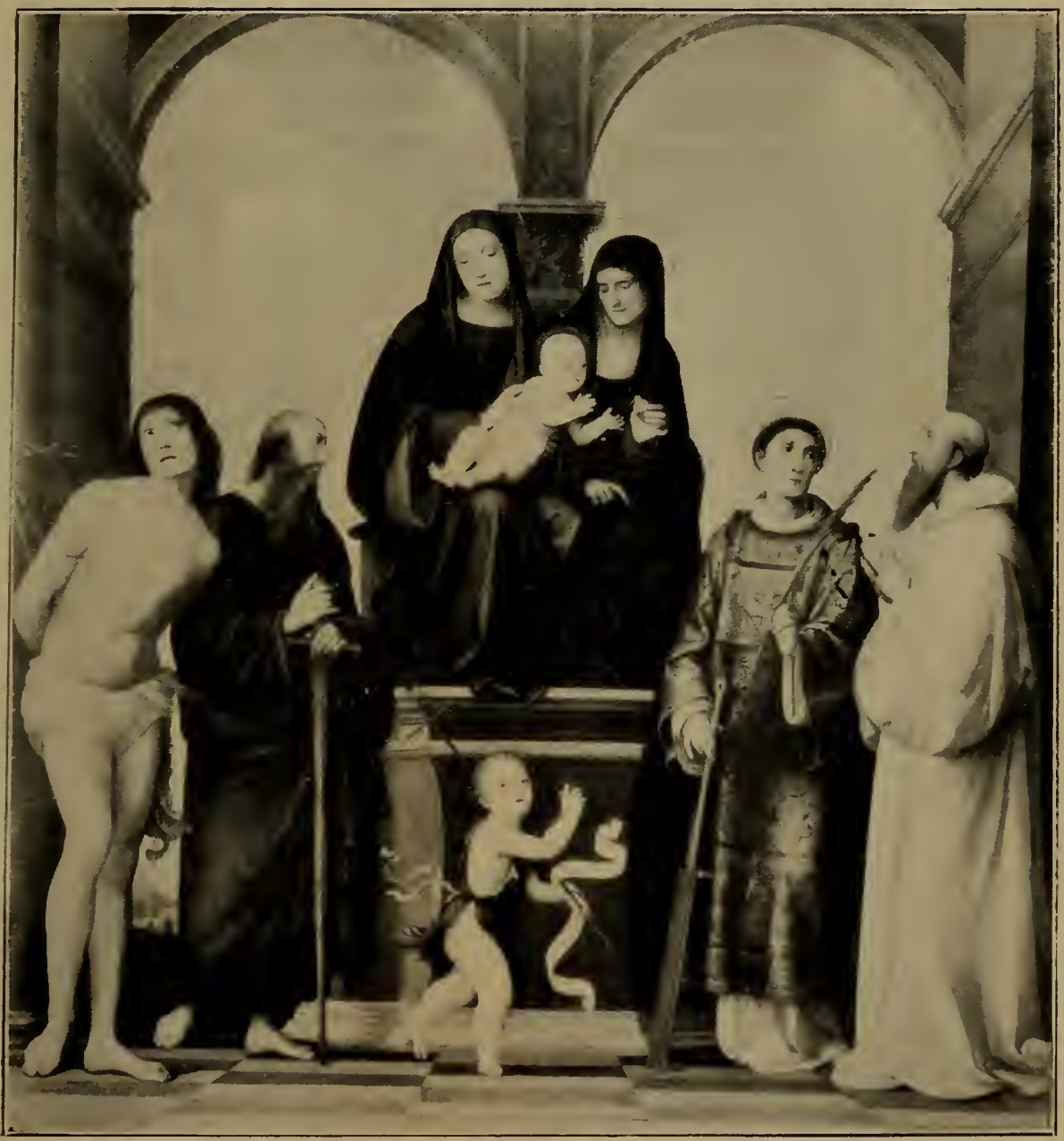

"THE VIRGIN WITH THE INFANT CHRIST, AND ST. ANNE ENTHRONED, SURROUNDED BY SAINTS" (179) BY FRANCESCO RAIBOLINI (CALLED FRANCIA) 

THE FERRARESE AND BOLOGNESE SCHOOL 77

upwards towards the mother and Babe. Below is a delightful child, John the Baptist, carrying his cross and a scroll on which are inscribed the words, "Ecce Agnus Dei." He trips along pointing upwards to the Baby in its mother's lap. There are many charming children in the National Gallery, but none is more lovely than is this child with his dancing step and his grace of perfect innocence.

I must tell you of the death of Francia, as Vasari, the prince of chroniclers, tells it. $\mathrm{He}$ and the divine Raphael were friends although they had never met, but they had "saluted each other by letter," and they corresponded and loved each other. Francia was old and could not leave Bologna, but he longed greatly to see some work by Raphael. His wish was fulfilled. One day he received a letter from Raphael telling him that he was sending a picture of St. Cecilia to the church of San Giovanni in Monte at Bologna. He begged Francia to supervise the hanging thereof, and, as a favour to himself, to repair any damage that might have happened to the picture. Francia was happy; at last he was to see a picture by Raphael. When the case came he had it opened before him, and when he beheld the St. Cecilia he was struck dumb with wonder at its beauty. He looked at it till his eyes were full of its loveliness, and then he realised that nothing that he had done could compare with the splendour of Raphael's work, that all the praise lavished upon him by his compatriots was undeserved. He had St. Cecilia carefully put up in the chapel, but he 
had received his death-blow. It had been given when he discovered the greatness of the difference existing between him and Raphael. He went home in a state of great depression, took to his bed, and in a few days he died of melancholy.

The other pictures in this room I am sure you will appreciate later on.

But I should like to draw your attention to those by Dosso Dossi, who held a high place among his contemporaries, and was called "The Titian of the Ferrarese School." He was born at Bologna, I479; he died in $\mathrm{I}_{542}$, and was a pupil of the Ferrarese Lorenzo Costa. He is very badly represented in the National Gallery, but he has won a very remarkable name for himself; and in churches and galleries on the Continent you will see him at his best. Dossi was not of a religious spirit, and his finest works treat of mythological subjects. His colour is very rich, and he is said to have painted excellent portraits. This picture, "The Adoration of the Magi" (640), is principally remarkable for the hilly landscape with trees in the background, and "A Muse Instructing a Court Poet" has much in it that is interesting. The head of the poet is said to be a portrait. Dosso Dossi, is not to be judged by either of these pictures. 


\section{CHAPTER XIII}

\section{PADUAN SCHOOL: ANDREA MANTEGNA}

"Let us pray

God's grave to keep God's image in repute."

"THE Paduans are great scholars," says an Italian proverb, and from that city of classic traditions comes Mantegna. He may be said to be the only illustrious painter of the school. Squarcione-of whose work the National Gallery possesses no example-was its founder, Mantegna was its crown. $\mathrm{He}$ was of humble origin-a little lad who kept cattle in the fields, and who, one day, Squarcione took home, adopted, and taught (I43I-I506). The artist was renowned as a teacher and the boy was his favourite pupil.

When Andrea Mantegna grew up he became intimate with his master's rivals, Jacobo Bellini of Venice and his two sons, Gentile and Giovanni. He ultimately married the daughter Niccolosia. Squarcione was angry at Mantegna's friendship with the Bellinis and would have nothing more to do with him.

He surpassed all rivals in the sense of style, this one great painter of the Paduan school. Squarcione complained that Mantegna's pictures looked like sculptured reliefs, forgetting that it was he who 
had not only taught him drawing, but had taught him to reverence the immortal works of antiquity. Squarcione had travelled through Greece and Italy, and had brought home casts of all the noble statues. His pictures are formal ; they entirely lack inspiration, but he was unrivalled as a teacher. Mantegna, from study of the casts his master had brought home, acquired a magnificent sense of form and of drapery.

His two pictures-" Samson and Delilah" (II45) and "The Triumph of Scipio" (902) - were intended to represent sculptured reliefs. Scipio has been chosen by the senate as the worthiest man to receive the image of Sybele; the goddess is seen carried in a litter. The wild figure of Claudia, mad with joy at having established her innocence, flings herself before the image. It depicts Mantegna's power of presenting violent passion and movement. In these he had no rival. You must study these wonderful monochromes; they show Mantegna's severe and statuesque ideal, his restrained emotion. They show above all his enthusiastic love of the antique-a love that he shared with his time and that made him its exponent. In them he gives way to no soft feeling, but if you will look at his picture, the "Mother and Child" (274), you will see that he can be tender enough. The Virgin is a country girl all womanly and simple, holding her Baby on her knee. On either side of her stands St. John the Baptist and Mary Magdalene-magnificent figures clothed with the most elaborate drapery, the folds of which display rather 


\section{PADUAN SCHOOL : ANDREA MANTEGNA 8I}

than hide the outline of their forms. The Magdalene, looking upwards, holds the box of ointment which she is later to break over the feet of the divine Son of man. St. John the Baptist bears a cross, to which is attached a scroll carrying the inscription in Latin, "Behold the Lamb of God." The Virgin, with her shrouded head, is clothed in the same extraordinarily beautiful drapery. There is a shrinking sweetness in her look and attitude. This picture is one of the immortal works in the National Gallery; it will appeal to you more than the sculpturesque friezes that also bear Mantegna's signature. 


\section{CHAPTER XIV}

VENETIAN SCHOOL

\section{"Once did she hold the gorgeous East in fee; And was the safeguard of the West: the worth Of Venice did not fall below her birth- Venice, the eldest child of Liberty."}

LET us now enter the long room of the National Gallery, the largest of all the rooms. There we shall see the pictures of the Venetian school-Venice, the Republic, whose merchants were princes, whose people were free born, and whose doges rank with the highest potentates of the world, is here. Rich, luxurious, and powerful, she was the bride of the Adriatic. Every year her doges wooed the sea and wedded it with the marriage ring that they threw into its waves.

The Venetian school of painting was a school of colour, of light ; it pictures a free, joyous, opulent life. As you stand in this room, you have a great sense of splendour-splendour of drapery, splendour of architecture, splendour of physical beauty; it is the happy noon-tide of art. Lovely women, blonde, red-haired, of massive types, surround us. They contrast with the slender forms, the more intellectual and spiritual physiognomies portrayed by Leonardo da Vinci, by Botticelli, by Raphael. 
Never has colour been used so boldly and successfully; never has light and shadow produced more dramatic effects. Religion was the source of the art of Venice as it has been the source of every art.

In the early half of the fifteenth century the Vivarinis were a family of painters; natives of the island of Murano, they heralded the foundation of the Venetian school. Murano is an island of the lagoons on the north of Venice; it lies so close to the city "Queen of the Adriatic," that the gondolas congregate there at holiday time. The Vivarinis lavishly inlaid their pictures with gold, so that they look half goldsmith's work, half that of painters. Antonio Vivarini was a native of Murano, and he had for partner a German named Johannes; but in $145^{\circ}$ he sundered his partnership and associated himself with his younger brother Bartolommeo. They had a younger kinsman, the most gifted of the family, Luigi or Alvise. We have in the National Gallery two panels of saints by Antonio Vivarini which I want you to look at $(768$ and I284). They are panels embossed with gold; the gold is inlaid with precious stones. The transparent colour is very beautiful, and the work is altogether serious and dignified.

The Vivarinis were the only rivals Giovanni Bellini had to encounter when he came and settled in Venice, about 1460 , with his brother Gentile. Both were pupils of their father Jacobo, who belonged to the Paduan school, and who was a man of some distinction. 
Before looking at Bellini's pictures I should like you just to glance at the "Annunciation" by Carlo Crivelli, an artist who was born in Venice about I430. He was a link between the old school that was very much under Byzantine influence and the new school of which Giovanni Bellini was the leader. Crivelli employed gold and silver as did the Byzantines; he painted in transparent and brilliant colour, using gold so skilfully that it seems to be part of his palette. He delighted in lovely and gorgeous details, in splendid masses of colour, in magnificent stuffs, in rare ornaments. We have in his pictures a foretaste of the colouring of Paul Veronese, of the opulent effects attained by the use of flowered brocades. There are eight pictures from the hand of Crivelli, but we shall look at one only-" The Annunciation" (739). It is an exquisite little work, very naïf in sentiment. Through an open door we see the Virgin kneeling in a sumptuously furnished room. From a window above hangs a carpet, a rich medley of tints such as the looms of Venice alone could weave. A peacock of iridescent hues stands on the ledge above. The angel of the "Annunciation" is kneeling in the street outside the window at which the Virgin is praying, and by the angel's side is St. Emilius, carrying a model of the city of Ascali. A ray of light pierces the roof of the house, and a dove descends upon the Virgin's head. Many figures are in the street; some are aware of the ray of dazzling light, and are scared and troubled at the phenomenon. A little child from a balcony opposite is peeping timidly, wonder- 
ing what is happening in the house over the way. It is a delightful picture, full of story, most perfect in all its details, full also of interest in human beings.

And now let us look at some of Giovanni Bellini's works. He is the real founder of the Venetian school, the school that revels in the glory of the world. Let us first look at "Christ's Agony in the Garden " (726) It is a very early picture by Bellini ; it was painted nearly fifty years before he painted the superb portrait of the Doge Leonardo Loreano. The sun is setting, the sky is suffused with rosy radiance : this is said to be the first painted sunset in the National Gallery. How beautiful is the quiet twilight descending on the hills, contrasting with the splendour of light in the sky. Christ is kneeling somewhat apart from His disciples, who have been overcome by sleep. In the distance we see Judas approaching with a crowd of Jews. Our Lord is praying in His mysterious agony, and lo ! the heavens have opened and an angel is descending bearing a cup. The picture is full of peace. We feel that Bellini was a true Christian, and that, as he painted, in his heart was a passionate love for our Saviour.

The portrait of the Doge Leonardo Loreano in his state robes (I89) next claims our attention. What a portrait that is! The power of differentiating individuals is the secret of portraiture, and the Venetian school excels in portraiture. We seem to see the Doge as he was in life, fearless, astute, the representative of a mighty Republic against whom the great powers of Europe had formed 
a league-the league of Cambrai. Look at his wise, challenging eyes, at his resolute jaw, at the dignity of his carriage, at the courage breathed by his whole personality. $\mathrm{He}$ is secure in his own wit and bravery and in the faith of his people. Do you not seem to know the Doge wearing that curious peaked cap, that white and gold brocaded mantle? The picture is painted in oil. Bellini was one of the first to adopt the discovery of a new medium by Van Eyck. He had painted in tempera, now he abandoned it and took to the pellucid and golden oil.

It is believed that he was taught by a Sicilian painter named Antonello da Messina, who had learnt the secret of oil painting from Jan Van Eyck. When I come to the Flemish school I will tell you more of Van Eyck's discovery. Let us look at the "Madonna and Child," often called "Madonna of the Pomegranate" (280), one of the loveliest Madonnas in the National Gallery, with her shrouded head and eyes full of sorrow. She holds her Babe, a noble boy with auburn curls and dark eyes like His mother's eyes. There is also from Bellini's palette, "The Blood of the Redeemer" (I233), a pathetic and appealing picture, full of mystic teaching. Every detail seems put there to emphasise its meaning that Christ died for man. "The Death of St. Peter Martyr" (8I2) is a noble landscape; heavy intricate masses of foliage glow in the light of afternoon, and in a glade of the wood takes place the murder of Peter, the general of the Dominicans. He was a fanatic, and he was hated for his cruelty. 
On that day he was going in search of an enemy of the Church, and men waylaid him, cleft his skull, and left him dead on the spot. Strange it is to see how undisturbed are the woodcutters, the dogs and all the people about. "There must be serenity for perfect beauty," says Mr. Ruskin. Perhaps it is for this that nothing disturbs the sense of peace and of labour. There is not a drop of blood upon the robe of Peter or upon the weapon of the assassin. All is sunshine and quiet about the violent deed. Splendid as is the painting of this picture, we ask is not reality too much sacrificed to the claims of art ? There are other pictures by the founder of the Venetian school, among them a portrait of St. Dominic (I440) wearing the black and white habit of his order, carrying a lily in his hand. It is a fine and serene portrait.

Bellini died November 24, I5I6. 


\section{CHAPTER XV}

\section{VENETIAN SCHOOL (Continued)}

" She holds the flower to heaven, and by his power Brings heaven to the flower."

WE must hurry along looking at the representative pictures only of each painter. Oh! the beauty of that long room, the beauty of all the canvases hanging on these walls, the splendour of Titian, the gentle peace of Bellini, the impetuosity of Tintoretto, the magnificence of Veronese. All Venice seems to be here! There is joy in the sense of loveliness-the loveliness of colour, of subject; it creeps into our hearts. It is a splendid company we are amongst-Bellini, Titian, Giorgione, Tintoretto.

Here is "St. Jerome in his Study" (694). The picture was long ascribed to Giovanni Bellini; now critics universally agree that it is by another painter. It is believed to be by Catena, who formed his style and colouring on those of the master. How delightful is this picture. Could we not spend hours in studying it? We see that it is a lovely day full of sunshine. The serene and limpid atmosphere comes through the open windows, and we catch a glimpse of the country beyond. It is Italy, but the painter wishes us to imagine that we are in Bethlehem 
where St. Jerome had built a monastery. How dignified is the appearance of the saint as he sits in his study absorbed in reading the Scriptures. There is not a grain of dust anywhere. The doors of the cupboard are open; we see his books inside, his candlesticks, all his homely belongings. The old lion is dozing at the saint's feet, gentle and docile, and there is the little brown partridge that he cared for looking at his old slippers. His hat also is there. What a quaint and dainty scene it is, the picture of a holy life serene and prayerful.

Now let us look at "A Warrior Adoring" (234). The painter is unknown, but it is believed to be by Catena; and if you look at this picture and compare it with "St. Jerome in his Study," you will see that there is much resemblance in the scheme of colour. How full of worship is the figure of the adoring knight, prostrating himself before the infant Saviour sitting on the knee of the Virgin. Joseph, the knight's squire, even the horse-all seem under a spell of peace. This picture is filled with a sentiment of adoration. Catena died I53I.

Now let us pass to and pause before the immortal picture, "Bacchus and Ariadne" (35), by Titian (I477-I576). It is a glorious poem in paint-a poem of the joy of life. Theseus, who had loved Ariadne, has abandoned her, and she is on the sea-shore watching the sail that has borne her false love away. Presently there comes through the wood the sound of cymbals, of hurrying footsteps, of merry laughter. There dashes in the god Bacchus on his car driven by leopards, a train of revellers 
behind him. They are led by a satyr child stepping high on furry legs; his roguish eyes look out full of mirth, his head is crowned with white flowers that catch the light. One blossom has fallen at his feet and shines whitely there. I have said there are many beautiful children in the National Gallery, and this is pre-eminently one of them. $\mathrm{He}$ is the incarnation of childish life and joy. How full of animation is the picture, how full of colour; all the dancing figures are golden brown. We seem to hear the turmoil of the merry crew. The blue sea, the blue sky, the blue distance show up the glowing colour of the crowd of revellers. Look at the grace of the figure of Bacchus as he steps from his car to greet Ariadne. It is a picture full of the rare union of poetry and painting. And here is another lovely scene-the "Madonna and Child with St. John the Baptist and St. Catherine" (635). This saint is embracing the little one with rapture. See how charming is the face of the Madonna and of the kneeling and adoring St. Catherine, who is taking the Babe in her arms. Look at the beautiful landscape behind, woodland and plain, sky and water. It is believed to be a picture of Cadore, the birthplace of Titian.

Of Titian's portraits it has been said by Vasari, "There is no lord of note, or prince, or great lady who has not been painted by Titian." The National Gallery possesses but one undoubted portrait by him -it is that of the "divine Ariosto," as his countrymen loved to call the poet who wrote the "Orlando Furioso." He was Titian's beloved friend, and, in 


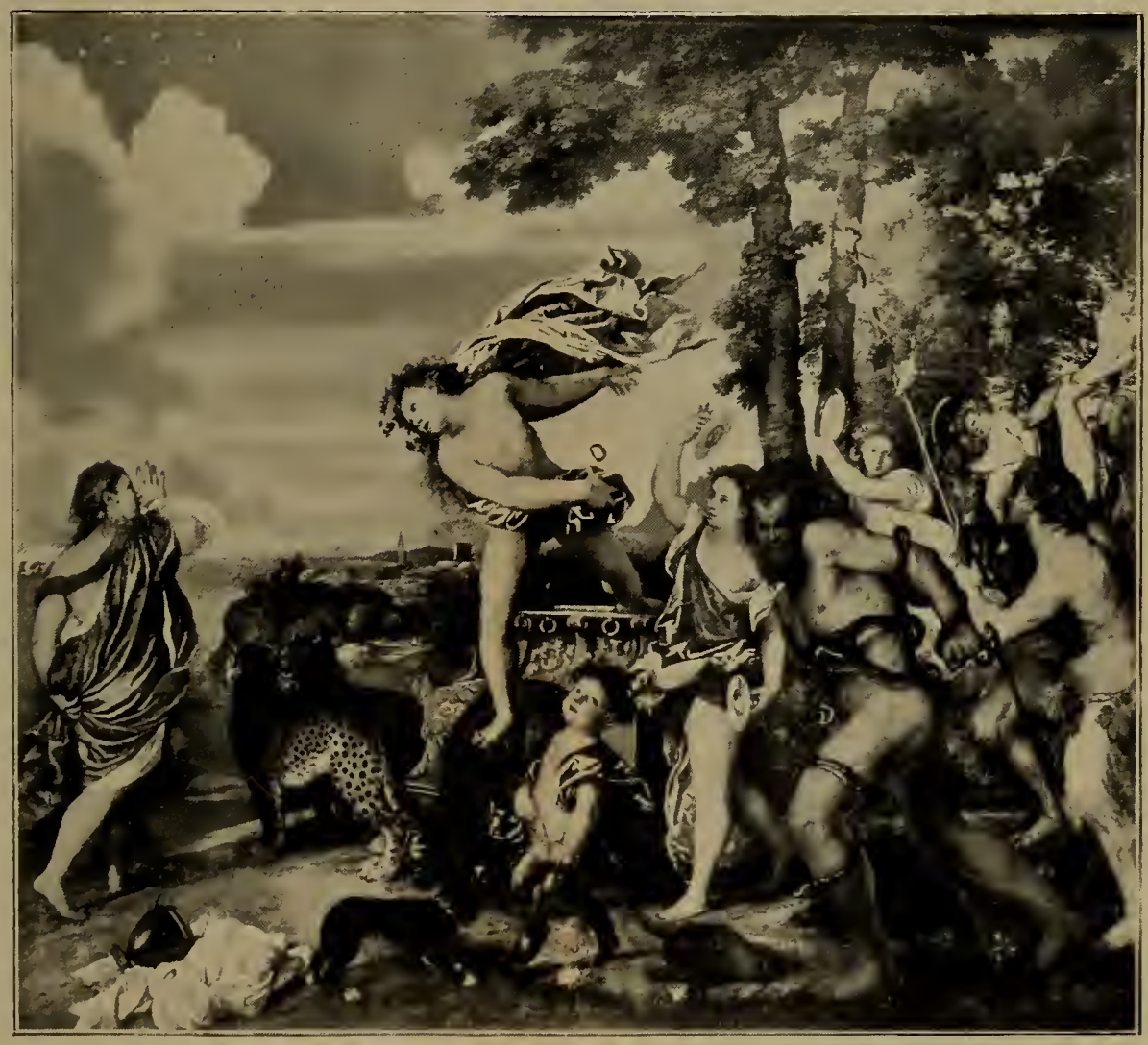

"BACCHUS AND ARIADNE" (35) BY TITIAN page 90 

his poem, he speaks of the "honoured Cadore," the little town among the hills where the painter was born. One portrait- "Portrait of a Poet" (636)-was first ascribed to Titian, then to Palma Vecchio; now some say it is by Giorgione. It is the portrait of a languid, suffering, intellectual looking man gazing out of the canvas; his whole pose expresses fatigue. Behind his head is a laurel tree, the leaves of which form a background to the sad and weary countenance.

But the undoubted portrait of Ariosto (I944) by Titian shows the poet looking over his right shoulder with a somewhat supercilious and sceptical expression. His hair, his beard, are of ruddy brown; he is splendidly attired in grey brocade, and the doublet is cut low at the throat. We seem to see Ariosto before us, aloof of bearing, observant, sensitive. When you read the "Orlando Furioso" you must think of that portrait painted by his friend Titian, the greatest painter of his age, as Ariosto was accounted one of its greatest poets.

Titian was very much influenced by Giorgione, who had been his fellow-pupil in Giovanni Bellini's studio. Giorgione went to Florence, met Leonardo da Vinci, studied his works, imitating his manner of modelling in light and shade, of melting the colours together, and throwing the objects in greater relief. It was Giorgione's habit to draw with his brush; he used no cartoon for his pictures, and he influenced Titian to adopt this method. It was a great revolution in the latter's work. His last pictures are boldly painted in large masses of colour, 
his first were painted with extreme care and diligence.

Titian lived to ninety-nine years of age. He received princes and the learned and famous men, and he was greatly beloved, for his manners were "most pleasant and courteous."

Giorgione (I477-I5II), whom I have spoken of as influencing Titian, was born at Castelfranco. He was of low origin, but his manners were dignified and gentle. Brought up in Venice, he sang and played divinely, but it was to drawing that he devoted himself. He loved nature, and he would never draw but direct from her. I have told you that he went to Florence and imitated Leonardo da Vinci's manner, giving great depth to his shadows, blending and softening them and concentrating his light. He was one of the greatest painters of a great age. His contemporaries, recognising his genius, called him, playfully, "George of Georges" (Giorgione). The influence that he exercised over Titian is still a living force, inspiring many painters of to-day. Giorgione understood the true language of the brush, each stroke of which was, as it were, a word in a poem, and his pictures were lyric poems of pleasant places, of summer sunshine, of the sound of running water, of luxuriant vegetation, of people indolently happy enjoying the scenes. Usually you will find tokens of his love of music in his pictures. Very often we see a shepherd or a knight piping to the girls about him. Musical instruments lie on the ground. Giorgione loved life; he loved the beautiful world, the brave and 
dignified men, the charming women in it ; his spirit was attuned to pure and sweet emotions. With all his poetry he was a realist. He never sought inspiration outside this world. Men and women, fine scenery, were enough for him. His colour was glowing. No colour ever glowed as does that of Giorgione. It was the true Venetian colour, full of sunshine, full of the glamour of the ever-changing sea.

In the National Gallery we have but one picture that we can be certain is his-" The Knight in Armour" (269). It is a small, highly finished study, believed to be intended for San Liberale, one of the figures in the great altarpiece that he painted for his native village Castelfranco. It is a wonderful little painting; the bronze colour of the knight's complexion, the extraordinary lustre of his armour are unapproachable. We cannot appreciate the genius of Giorgione from that study, and yet it makes us understand the reason of his influence over others. He was thirty-four when he died, dying in his prime, as if his buoyant genius could not face old age and the lassitude of life. Pictures belonging to his school are here. If we take "The Garden of Love" (930) we see a scene that might well have fascinated the master, but the painting is not his. If we look at "An Unknown Subject" (II73) we see a strong picture, captivating in its mystery. With "The Knight in Armour" and perhaps with "The Adoration of the Magi" (Ir6o) we exhaust all that we have of Giorgione.

Tintoretto (I5I8-I584), who, with Titian, Paolo 
Veronese, Bellini, and Giorgione, resumes the genius of the Venetian school, is also very slightly represented in the National Gallery. He was the painter of impulse, vehement and unfettered. $\mathrm{He}$ flung the emotion of the scene on the canvas. His execution was so rapid that his contemporaries nicknamed him "Il Furioso." $\mathrm{He}$ was very unequal in work; the Venetians said he had three pencils, "one of gold, one of silver, and one of iron." Look at his picture of "St. George and the Dragon "(I6). The story is dear to every English boy and girl, and it has never been presented as it is here presented. The earth, the sky, the very air seem charged with the tremendous energy of the moment. St. George, riding on a white horse, the emblem of purity, has attacked the loathly dragon, the emblem of the soul's evil passions. From his mouth the dragon spits fire. Before the saint is the dead body of a man killed by the monster, and the princess, who was to have been sacrificed to the foul beast, has sunk on her knees, lifting her hands to heaven in supplication. There is the sense of a mighty storm passing over the face of the earth. In the other pictures by Tintoretto we have the same sense of mighty life. In "Christ IVashing the Disciples' Feet" (II30) and in "The Milky Way" (I3I3) we recognise his dominant force. He was sixty-five when he died. 


\section{CHAPTER XVI}

PAUL VERONESE, SEBASTIAN DEL PIOMBO, AND THE GREAT PORTRAIT PAINTERS

"The rich heritage, the milder life.

Of nations fathered by a mighty Past."

LET us now look at the works of Paolo Veronese, the artist who, with Tintoretto, carried on the traditions of the Venetian school, to the dawn of the seventeenth century. Paolo Veronese was above all things a painter. What I want you to understand by this is that he was a master of expression in a difficult and complex language. He had the gift of colour and the gift of line. And what did he say in that strange tongue, how did the world appeal to him ? It appealed to him through its wonder, through the dignity of its men and the beauty of its women, through the stateliness of its architecture, and the glory of its sunlight. He did not care for exactitude. He treated correctness with superb indifference. He dressed his women in the splendid brocades woven in the looms of Venice, he clothed his men in the armour of his time. The last born of the greatest painters of Italy (I528-I588), he was the most gloriously ornate of them all.

Look at his great picture, "The Family of Darius 
at the feet of Alexander" (294) after the battle of Issus, 333 B.C. These magnificently dressed women are imploring for the body of their loved husband and father. They mistake Hephæstion for Alexander. The conqueror is a simple and dignified figure in armour. The palace in which the widowed wife and the fatherless daughters are kneeling is the hall of an Italian palace; perhaps it is that of the Pisani family, for whom Veronese painted this immortal work. Among the princesses, in their laced bodices and flowing gowns, is the daughter of Darius, whom Alexander later wedded. Bucephalus, the splendid war-horse, is here, and here also is a monkey, and all the accessories of pomp and state.

And now let us pass from that scene of splendour to No. (ro4I). It is the picture of a single figure -of St. Helena seeing the vision of the cross. The saint is sleeping on a marble window-seat in the limpid sunshine of Venice. She rests her head upon her right hand, and behold the heavens have opened and angels are descending holding aloft the cross. See the look of rapture that is stealing over her slumbering face as she beholds the holy symbol by which her son Constantine will conquer. Look how charming is the modelling of the figure, the disposition of the folds of her crimson gown, how tranquil and exalted is the atmosphere about her. When she wakes she will set forth for the Holy Land; she will visit the hill of Calvary, searching there for the implements of torture that were buried in the spot where our Lord was martyred.

There are many other pictures by Veronese in 


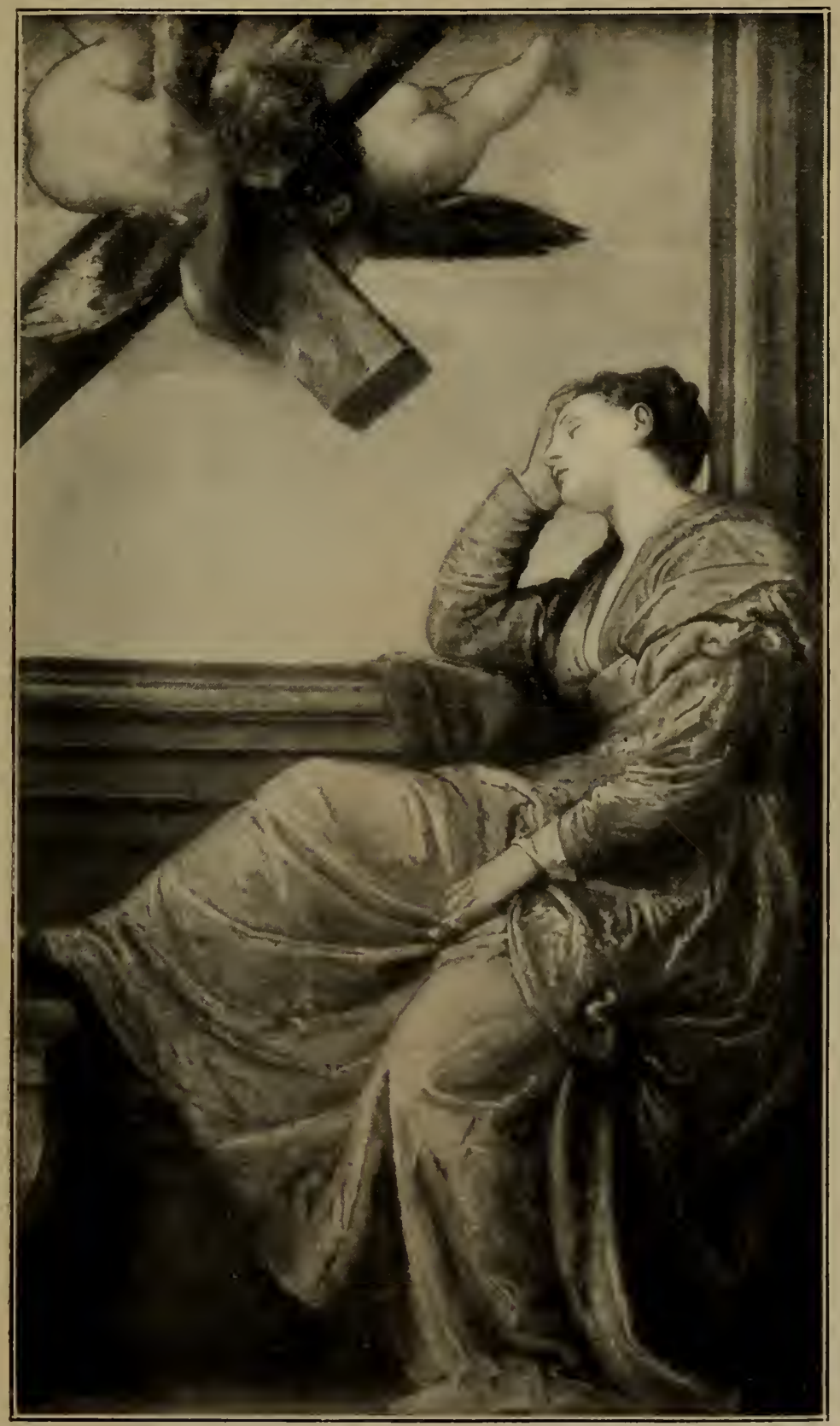

"THE VISION OF ST. HEIENA" (1041)

bY PAOLO CALIARI (CAILED I'AOLO VERONESE)

page 96 


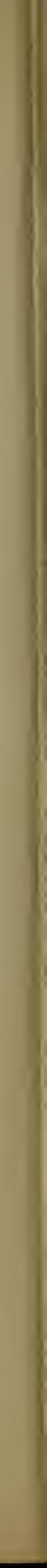


the Gallery, but if you study these two you will know how to appreciate his genius. With our eyes filled with the splendour of Venetian colour, let us look at "The Raising of Lazarus" (I) by Sebastian del Piombo. It is a picture very interesting in the history of art, but I think it is disappointing. Its emotion is remote with that curious remoteness that comes when our hearts do not throb as we look at a moving scene. Sebastian del Piombo was a laborious painter; he worked hard, but painting did not come easily to him. Vasari tells us that "The Raising of Lazarus" was painted in rivalry to the "Transfiguration" of Raphael, and that Michael Angelo helped Sebastian with the drawing. Raphael's "Transfiguration" and Sebastian's "Raising of Lazarus" were exhibited together. The two pictures received great applause from all who saw them, and some people preferred Sebastian's work.

There are two drawings at the British Museum of the figure of Lazarus by Michael Angelo, showing that he had helped his friend in this picture. The moment chosen for the subject is the one when Lazarus comes forth bound hand and foot in his grave clothes. Christ is in the centre of the picture pointing to heaven; Lazarus is looking eagerly towards Him. Pharisees, disciples, men, and women are about. Mary is sitting at the feet of the Saviour; Martha is behind her brother. It is a grim, realistic picture, filled with repulsive details. Sebastian soon after, on entering the monastic life, became keeper of the leaden seal, a well-paid appointment that he obtained from the Pope. $\mathrm{He}$ gave up 
painting; he took life easily henceforth, and never troubled any more about work. His friends would remonstrate with him. Why had he lost all ambition? Why did he not set to work and achieve great things with his brush?

"No, no," Sebastian would answer laughing; "there are so many clever fellows about, I am well out of the struggle. They can do in a month what would take me a year to achieve. It is a good thing that some people should do nothing," and he remained quite firm in his resolve. He never painted again. When you look at that large canvas of "The Raising of Lazarus" you must think of Sebastian del Piombo, who became a monk and who retired so early from the life of struggle. I think that through the centuries I hear him laugh as he answers his friends, "No, no; there are so many clever fellows about, I am well out of the struggle."

Now let us look at the portraits-the lifelike portraits that bring the men and women of Venice and its neighbourhood before us to-day. Truth and beauty are the two considerations the artist must keep before him in painting a portrait. The earlier portrait painters aimed at fidelity to nature more than do the painters of a later period. Here, in this great Gallery, we see the men and women as they took part in the life of Venice in the fifteenth and sixteenth centuries.

There are two great portraits by Il Moretto (I498I555), who was a native of Brescia, close to Venice. His father was a merchant. Il Moretto painted 
almost entirely for his native town. His nickname of "Blackamoor" is very inappropriate to his work. He chose a cool, tender, and harmonious scheme of colouring. His two portraits are of Italian noblemen. They have the noble bearing, the dignity and grace of the grandees of Italy. The first Count Sciarra Cesaresco (299) shows us a magnificently attired man in satin and ermine, with a plumed hat, resting his head on his hand. There is something melancholy and aspiring in his attitude. The second (I025) is probably the portrait of a member of the Fenariola family. In this portrait, the cool and splendid colour, the depth of expression, the ease and grace of carriage are marvellously depicted. They make us understand the spell that Il Moretto exercised as a portrait painter.

Moroni, his pupil ( $1525-I 578$ ), was not so successful with the noblemen of Italy, but he shows himself eminently gifted to represent the character of the men and women who have lower claims of birth. His lawyer (742), so alert and inquisitive looking; his ecclesiastic (I024), so important ; and, best of all, his tailor (697)-are all masterpieces. We seem to know them all. The lifelike attitude of the tailor, as he stands scissors in hand, looking towards us with an enquiring expression, makes us realise that the men of the sixteenth century were very like the men of to-day.

"Tagliapanni" -for this is the tailor's name-I think I hear one of you boys say, "how much cloth will I want for a jerkin ?"

And Tagliapanni, looking as he looks in the 
picture, scissors in hand, answers, "That depends, little sir, upon the fashion of the jerkin you want."

Another remarkable portrait painter is Lotto (I476-I555). He gives us the likeness of the "Prothonotary-Apostolic Juliano" (II05). Prothonotary means the chief of what may be called the Record Office of the Church. His business is to draw up reports on all important Church functions, such as the enthronement of new popes and other public functions. If we remember that the artist impresses his personality on the portraits he paints, we shall recognise how charming was the inner self of the painter Lotto. He has given a great elegance to this portrait of a scholar. How charming and cool is the colour, how beautiful is the drawing, the calm and thoughtful brow, the wise and weary eyes, weary with much reading-

"The low man seeks a little thing to do,

Sees it and does it :

This high man with a great thing to pursue

Dies ere he knows it."

Lotto was a pupil either of Bellini or of Vivarini. He was a gentle, earnest man, passing most of his long life among the Dominican monks. Thus the peaceful inwardness of his life was reflected in his works.

There are many more portraits here that I cannot write to you about. Of the beautiful women I can single out but one-the golden-haired, bright, and sinister-eyed beauty by Paris Bordone (674). It is a portrait that makes us shudder as we look at it. The eyes are hard as jewels; there is something 
ruthless about them. A story is told about this woman, who lived a treacherous and a cruel life in a treacherous and cruel age. One day she wandered into a church ; looking towards the altar, she beheld a picture of herself painted when she was young and innocent. She was an angel there playing on a lute and singing. The memory of what had been overcame her, and she sank fainting on the floor. Tradition says that she entered a nunnery, and that she became a holy woman.

Bordone was born I500 and died I57I.

And now we must leave this entrancing room of the school of Venice. As we leave it we seem to be going out of the sunshine, out of an atmosphere of gaiety and colour. 


\section{CHAPTER XVII}

SCHOOLS OF LOMBARDY: THREE GREAT PAINTFRS

" Like a poet hidden

In the light of thought,

Singing hymns unbidden

Till the world is wrought

To sympathy with hopes and fears it heeded not."

THERE are three great masters whom I want you to study in the Lombard school-and in the Lombard school are included the school of Milan and the Parmese school. Of this last school Correggio is the delightful outcome. His bright, happy, debonair genius is the genius of Italy.

In the Lombard school one master deserves a very high place-Ambrogio Borgognone (I455-I523). He was a religious painter, who had something of the genius of Fra Angelico. There are several pictures by him in the National Gallery, but the finest of all is "The Virgin and Child with the two St. Catherines " (298). The Virgin is seated on a beautifully carved throne. She is a sweet and timid girl, who holds her divine Son in her lap. $\mathrm{He}$ is somewhat stiff, but there is charm in the expression of His face. His two little hands are extended, and in them He holds out two wedding rings. St. Catherine of Alexandria, the great princess who loved to meditate on holy things, and who endured martyrdom rather 
than marry a heathen prince, is receiving the symbol of her consecration to Christ ; on her head she wears a crown; at her feet is the wheel that was intended for her martyrdom; in her hand she bears the sword with which she was slain. The Virgin is gently drawing the other Catherine-Catherine of Sienatowards her Son. This pure and holy nun is the saint ministering to all those in affliction. She entered the monastic life at thirteen years of age, and, quite uneducated, she soon had more power over men and women than had learned theologians and statesmen. She stands there in the Dominican habit carrying a lily, the emblem of purity, wearing the ring that will make her the bride of Christ. It is a fine picture, beautiful in tone and full of sincerity.

Family portraits (779-780)-groups of nine men and thirteen women-you should also look at ; they will make you better understand the noble sincerity and simplicity of Borgognone's genius.

To the Lombard school belongs the gentle Luini, who, Mr. Ruskin says, "stands alone in uniting consummate art power with untainted simplicity and religious imagination."

We have but one picture by Luini- "Christ Arguing with the Pharisees " (I8). In many respects the picture is so like Leonardo da Vinci's work that it was long ascribed to this master. Every face therein is a study of expression. The Christ, who is the central figure, has a tender and charming countenance; on either side of His face falls His golden brown hair. The Pharisees about Him are puzzled 
and angry at His words, but $\mathrm{He}$ continues to explain His thesis with earnestness. I wish we knew more of Luini (I475-I529), who was born by the side of the lovely Lake Maggiore, and whose whole youth was spent in its neighbourhood. His colouring is so sweet and tender, the expression of his countenances is so deep that, without having much to go upon, we yet claim him as one of that army of old masters, one of those great men who held high the torch of art, and whom we follow humbly.

Correggio (I494-I534), of the Parmese school, is believed to have received his first training in the school of Ferrara. His name was Allegri, and the name suited his gay and happy nature, his bright and joyous art. The pictures we have from him are masterpieces. In the "Ecce Homo" (I5) the Christ is not a thin emaciated figure, but $\mathrm{He}$ is the most gentle and beautiful of men. If His face shows the anguish of His suffering there is no distortion of its features. In the little picture called "The Holy Family" or "The Virgin of the Basket" (23) we see Correggio's charm, his gaiety, his attractive tenderness, the loveliness of his light and shade. The picture is an enchanting representation of motherhood. The Virgin is putting a little coat upon her baby Son, and she is smiling at His attempt to pass His chubby arm through the sleeve. It is a perfect picture of domestic peace and happiness. It was Correggio's wife who sat for it and his own baby, and the scene was enacted in his studio; he sketched it and called it "The Mother and Child." 
The other picture, "Mercury instructing Cupid in the presence of Venus" (IO), is one of the most exquisite of Correggio's pagan pictures, if we may so call them. Ruskin says "The two pictures which I would last part from in the National Gallery would be Titian's "Bacchus" and Correggio's "Venus." We see Mercury wearing his winged cap and sandals, teaching the alphabet, which it is said he invented, to the baby Cupid. The little fellow's wings are rainbow coloured; his golden hair clusters in close curls round his head. He has a most absorbed mien as he learns his letters. His mother stands behind him, radiantly beautiful, apparently very much amused at her small son's scholarly efforts. She, too, is wearing wings;-perhaps it is to show that beauty flies,- - and she holds Cupid's bow and arrow. Her lovely form is nude, and every curve of her limbs is wrought in light and shade. She stands a glowing figure, one of the purest and loveliest ever painted. This great picture first belonged to Charles I. When he was beheaded it passed through many hands, and ultimately came into the possession of Murat, King of Naples. When the fortune of the Bonapartes was set in I822, Murat's wife wished to sell it; and Lord Londonderry bought it over Russia's head, giving the largest sum and carrying it over to England.

Other Correggios you will see in private galleries, in national museums, and wherever you see them you will always find them imbued with extraordinary life. His power of light and shade was 
unrivalled: his figures move about in a luminous ether. Correggio died when he was forty years of age, just three or four years older than was the immortal Raphael. He was the last of Italy's great masters. 


\section{CHAPTER XVIII}

\section{DECAY AND DECLINE \\ " Day is dying! Float, oh song, \\ Down the westward river, \\ Requiem chanting to the Day- \\ Day, the mighty giver."}

Now let us pass at once to the room where the later Italian pictures are hung. It is the decay of the Italian school that we have to watch, for painting has lost its spontaneity. The inspiration of genius has given way to mere technical skill. This school is called the eclectic school, for its followers sought to unite the excellences of many painters and lost all inspiration in the attempt. Ludovico Carraci was its founder. Tintoretto had warned him that he had no vocation for painting, that there was nothing original or vital about his methods. Julio Romano, AnnibaleCarraci, Canaletto, Guercino, Pietro Longuo, Giovanni Baptista Tiepolo, Salvator Rosa, Carlo Dolci, Guido Reni, and Sassoferrato were among the leaders of that school of decay.

Canaletto (I697-I768) is the painter of Venice, and he also painted London, where he resided two years, coming thither in 1746 . His pictures are marvellous representations of the carvings of the great Venetian palaces, accurate as photographs: he paints the gondolas, the canals ; but Venice, the land of limpid 
sunshine, of white marble, is a grey city in Canaletto's pictures. Sometimes it is "A State Regatta" (938) which he paints, and we see the windows and balconies all decked with tapestries and velvets; sometimes it is "The Grand Canal" (I058), one of the waterways of Venice, filled with the market people coming in boats that are laden with purple grapes and figs, scarlet gourds and crimson fish baskets flaming in the morning sun. The painted sails above and the sunburnt tanned limbs of the fisher folk glow. All the elements of colour are here as we see them to-day, but in Canaletto's pictures much is grey and colourless.

Guido Reni (I575-I642), who was a pupil of the Carraccis, was a native of Bologna. His father was a musician, and it was intended he should follow the same career, but he preferred painting. There is something very effeminate in his art. His "Magdalene" (I77) is an example of his curious overladen style.

Carlo Dolci (I6I6-I686), the son of a Florentine painter, is sentimental, affected, pretty in art. There is a painful smoothness in his compositions, there is nothing broad in his brush work.

Sassoferrato (I605-I685), who is a follower of the Carracci, has a certain sweetness and dignity, but lacks originality. "The Virgin and Child" $(740)$ is a good example of his art. There is in his Madonnas no stamp of the glorious inspiration of the great masters.

Salvatore Rosa's (I6I5-1673) "Landscape with figures" (I206) is a dark picture. It reflects the sad 
and interesting mind of the painter. Salvatore's life was the record of a disordered mind, full of contradictory impulses - baseness, courage, ambition, and despair. His pictures seem to be the work of a dark and tortuous spirit. It is said that he once joined a band of brigands in the Abruzzi, and that he sought there the solitude of the hills. Withered trees, dark abysses, rocks that seemed thrown up by a mighty earthquake were his favourite subjects. He had no religion: he said that he despised wealth and death. The thought of that strange man painting these gloomy and mysterious landscapes, these blasted trees, and nightmare vegetation, haunts our imagination. His dark and terrible pictures image the awful fancies of his mind.

But I shall not keep you long over this room. All the pictures are painful to look at. When we think of the glorious art of Italy-the exquisiteness of Botticelli, the holiness of Fra Angelico, the visions of Titian, the noble frenzy of Tintoretto, the rugged splendour of Michael Angelo, the infinite grace of Raphael, of Leonardo da Vinci, of Andrea del Sarto, the splendour of the line and colour of Paolo Veronese, we feel the sadness of decay in the smoothness of Guido Reni, of Carlo Dolci, in the chaotic ruggedness of Salvatore Rosa, in the absence of light of Canaletto's Venice-all showing contempt for what is natural and simple. 


\section{CHAPTER XIX}

\section{SCHOOL OF SPAIN}

"How much of my young heart, oh Spain,

Went out to thee in day's of yore!

What dreams romantic filled my brain

And summoned back to life again

The paladins of Charlemagne

The Cid Campeador !"

AND now we enter the room dedicated to the art of Spain, an art that flourished for a century. Some painters came before the great ones, but they were - poor heralds of the splendour that was to be-the glory then faded away. Ribera, Zurbaran, Velazquez, Murillo were all painting between $I 588$ and $\mathrm{I} 682$. Long years of sterility passed, and then Goya appeared, bringing some touch of the brightness of art into the early years of the nineteenth century.

Looking round the room we see the grave spirit of the Spaniards reflected in these pictures. Kings and monks, warriors and peasants, children of the people-all are here represented with wonderful naturalism. It is an art of truth to nature. The fervid piety, often verging upon superstition, of the Spaniards is imprinted upon every work. The Inquisition ruled the country. No taint was allowed to sully the purity of its art; it bade that angels should always have wings, and that the glorified Madonna should always wear blue and white, the 
colours she had worn when she appeared to the Portuguese nun.

Ribera (I588-I656) is the first glorious ray of the dawn of Spanish genius. He was a born artist, although his parents wished to devote him to the career of letters. His whole heart was in the studio of Francisco Ribalta. At last he was allowed to study there; and when he was still quite a youth the passion for art possessed him, and he ran away to Italy, the mother of beauty. He made his way to Rome, and began to study the frescoes there and to sketch from nature; always out in the open air, he endured privations of every description. A cardinal, it is said, discovered him absorbed in work, dressed in rags; dry crusts by his side that were given to him in charity. He took Ribera home, took care of him, made him one of his retinue; but the boy soon broke loose, and set to work once more in his own way. $\mathrm{He}$ became a powerful artist, studying effects of light and shade, caring only for strange and wild effects. He went through a phase of admiring the gentle Correggio, and set off to Parma to study his work. But Correggio's happy spirit did not suit the Spaniard's gloomy temperament, and he returned to his own dark and striking methods. Little by little he climbed to fortune and to fame. He remained a Spaniard at heart, although he worked in Italy. $\mathrm{He}$ was a realist with nothing of Italian idealism. There was no fancifulness or sweetness, no gaiety in his spirit.

"The Dead Christ" (235). We see the Virgin accompanied by Mary Magdalene and St. John, 
weeping over the body of her Son, now rigid in death. The cadaverous colours, the horror of the details, the angular lines of the figure emphasise the terror of the subject. It creeps into our hearts in all its darkness and gloom. There is no hope of the Resurrection. How different is this Pieta from the one by Francia, where the angels weep with the mother over the body of the Saviour, beautiful in the lassitude of death. Ruskin calls Ribera " the black slave of painting." He was impelled by a ferocity of jealousy. He settled in Naples, married the daughter of a rich picture dealer, founded a society, the meetings of which were held in his studio, whose object was by intimidation and intrigue to drive from Naples, by the use of the poignard if necessary, painters who might become his rivals.

Before approaching Velazquez, the incomparable master of the Spanish school, I shall say a few words of Zurbaran. Lord Leighton has said that "in Velazquez all was Spanish, but Zurbaran was all Spain." In his works, beyond those of other painters, is the very genius of the nation-a genius that was so subservient to the Church that it has been said that in other nations art was the handmaid of the Church, but in Spain it was its bondslave. The Spaniards are a fiery race, indifferent to beauty, full of dramatic instincts; their artists care for truth to nature beyond all things, and give with extraordinary vivacity the effects of light and shade. Realistic in their methods, they are strangely idealistic in their thoughts; they were hampered by superstition to a strange degree. In Zurbaran's 
time it was said that they would buy the cast-off cowls of monks in which to bury the dead, so that St. Peter would mistake their ghosts for those of holy men. Zurbaran's parents were simple labourers of Estramadura. They early discovered their son's genius and sent him to Seville to study under the painter-priest, Las Rodas. He seldom stirred from Seville, haunting the aisles and the cloisters of the cathedral. Velazquez met him and brought him to Madrid, but he soon returned to the Seville he loved.

"A Franciscan Monk" (230) is of all Spanish pictures in the Gallery the most characteristic. We cannot look at that kneeling monk in his brown and darned habit, his face hidden in the deep shadow of the hood, his emaciated hands clasping a skull, without seeming to see all priest-ridden Spain around us.

"The Nativity, or Adoration of the Shepherds" (232) is by common consent the finest picture by $Z$ urbaran. It was long believed to be the work of Velazquez, but research has at last given its authorship to Zurbaran. I want you to look at this beautiful painting so realistic and so holy. The Virgin, the adoring shepherds, are simple peasant folk; there is no attempt made to idealise them. The rustic offerings of lambs and fowls and other commodities are gifts according to the means of the shepherds. In the distance we see hovering above the guiding angel of the Epiphany-

"See the kinder shepherds round Him

Telling wonders from the sky!

Where they sought Him, there they found Him

IVith His Virgin-mother by." 
It is a picture full of reverence and of worship. The genius of the Spanish school is fully expressed therein-extreme realism mingled with extreme idealism.

Now we come to Velazquez, one of the greatest painters of all times and of all nations. His colour is silvery; he sings with his brush; his art reveals the sunniness of his nature. His marvellous facility was expressed by Sir Joshua Reynolds when he said, "What other artists tried to do with great labour Velazquez did at once." 


\section{CHAPTER XX}

\section{VELAZQUEZ AND MURILLO \\ "He did God's will ; to him all one If on the earth or in the sun."}

VELAZQUEZ was born in Seville in I599 of well-todo parents. They soon discovered that their son had a native talent for art, and he entered the studio of the elder Hirara, a man whose brutal ways soon drove the young artist away. Velazquez was then placed under the tuition of Francisco Pacheco, who appreciated his pupil's character and genius. The teacher was of a timid disposition, gifted for letters rather than for art, and Velazquez soon chose Nature for his guide. He copied birds, beasts, and fishes with scrupulous fidelity; he then began to paint man, studying the human form with the same extraordinary care. $\mathrm{He}$ was twentythree years of age when he married Pacheco's daughter. Then Velazquez went to Madrid to copy the masterpieces of the royal collections; there he attracted the attention of the minister Olivarez. After he had returned to Seville, the minister called him back to court and introduced him to the King. He was commissioned to paint Philip IV.'s portrait, and this was the turning-point of Velazquez's career. 
The portrait of the King was an immense success, so great that, by royal command, all other portraits were destroyed, and Velazquez was appointed Philip IV.'s private painter. He became also the King's intimate friend, but this exalted friendship did not affect Velazquez's nature. There was in him a certain austerity of soul that kept him devoted to work and remote from all the pleasures of the court. His kindness to the men of his craft never wavered. When he went to Italy, sent thither by the King to buy pictures, he visited Ribera. At another time he attracted Zurbaran to Madrid, and influenced the King in his favour; later he befriended Murillo. The contrast between Velazquez's magnanimous soul and that of Ribera is like the contrast between the glow of sunshine and the gloom of night.

There are two portraits by Velazquez of Philip IV. One (II29) is a slender, stately figure dressed in silvery brocade. Look at the wonderful painting, at the fine modelling of the face, at the intellectual brow, at the weak despotic mouth; look at the shimmering stuff done with unerring precision of touch. The King, his cold impassive countenance, his air of refinement and of high breeding, stands before you in all the remoteness of rank. Then let us look at the sovereign (745) in middle life. We seem to see the story of the years that have elapsed. Once more we recognise Philip IV., careless, weak, art-loving, indolent, singularly impassive, with his cold physiognomy, expressive of his talent for freezing silence. His dress is black and gold. In 



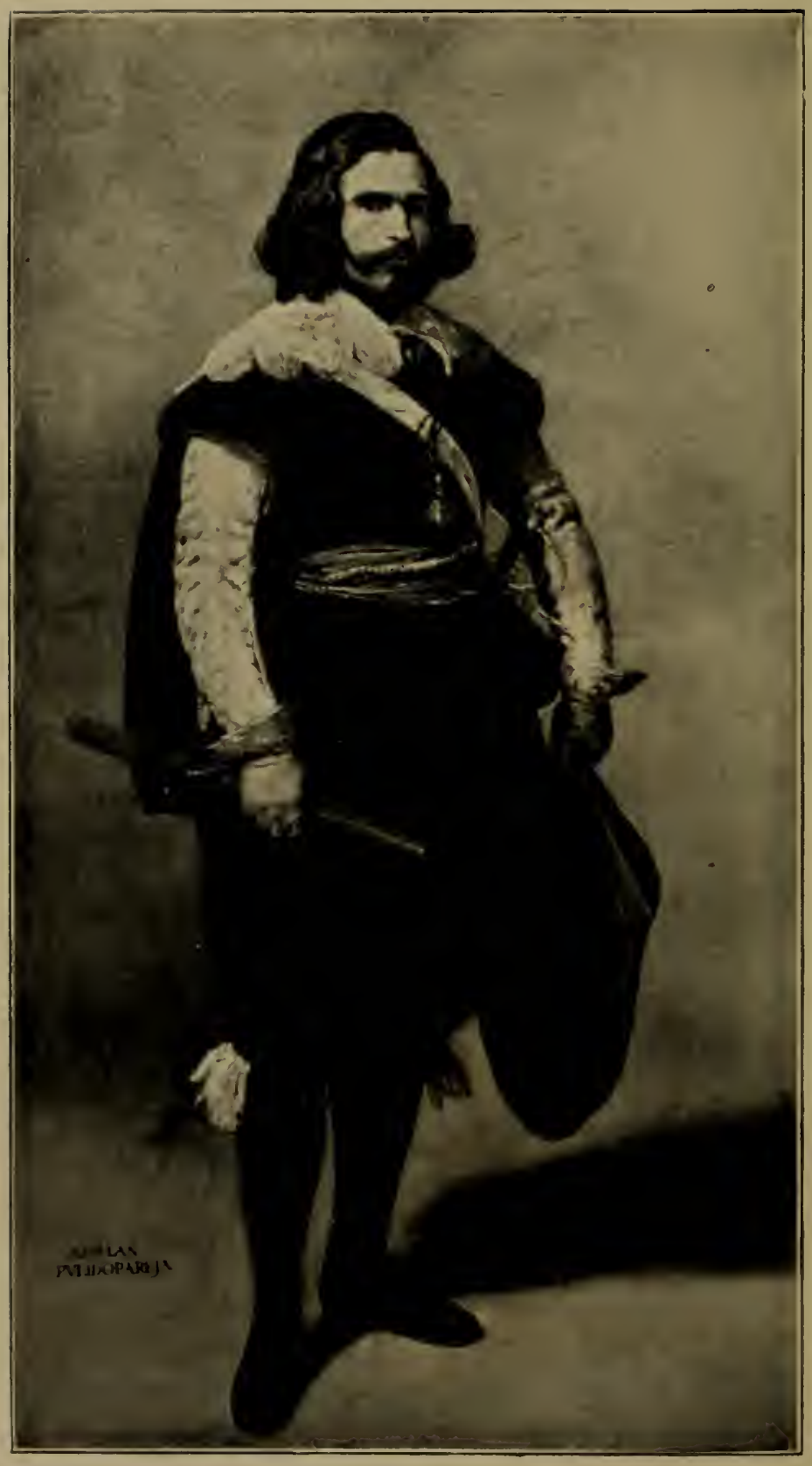

"POK'RAT OF THE SPANISH ADMIRAL PULIDO PAREJA" (1315)

WY VILALUUEL 
both portraits is conveyed the dignity of bearing, the graceful carriage that distinguished Philip. He is more impassive in his middle life than he was in his youth. He was not a great ruler, but he was an enlightened patron of the arts, and he had friendship for Velazquez.

Then let us look at that searching portrait of the Spanish Admiral, Pulido-Pareja (I3I5). He stands against a luminous grey background, and we seem to see him in the flesh. His doublet and breeches are of black velvet, his dark hair falls over his lace collar, his rugged face is alight with sombre eyes, his mouth is about to speak. The portrait is very living; it is one of the living portraits of the world. It has been said of Velazquez that he painted by his will alone, that he made no effort to hamper it.

"Venus and Cupid" (2057); this newly acquired picture seems to have been blown on the canvas, so light is the touch with which it has been painted. The goddess of beauty is lying on a couch, turning away from us to look into a mirror held by a Cupid. The colour is so fresh it might have been laid on the canvas yesterday. The figure seems moulded in light. Contrasting with the loveliness of this picture and the joy of its beauty is "Christ at the Column" (II48). Our Saviour has been bound by the wrists to a pillar ; no object distracts the spectator's attention from the woeful theme. His hands are swollen by the tightness of the cords. The blood is trickling down His shoulder, yet He looks round with ineffable compassion upon the little child who is kneeling in prayer to Him. The adoration of the fair-haired 
little one is beautifully conveyed. Pushed forward by his guardian angel, he kneels half-shrinking in awe from the God-man. It is a painful and dramatic scene. We see the influence of the Inquisition in the representation of the angel. She looks a woman but for the wings fastened to her shoulders. There are other pictures by the great painter in the room, marked by the same fidelity of brush work, by the same wonder of colour. Some deny to Velazquez the higher gifts of imagination, but all admit that he loved above all things nature and truth. I want you to study all the pictures that you can of Velazquez, and in them you will find that reality is the great characteristic of his art.

"The Dead Warrior" (74I), called "The Dead Orlando," was long ascribed to Velazquez, but it is now held to be by one of his pupils. It shows a dead knight lying full length in a cavern with a lamp at his feet; one hand lies on his breast, the other is on the hilt of his sword. It is a very impressive picture, which belonged to the Count of Pourtalès, and was in his gallery in Paris. I remember my mother telling me that on the day the works of art were exhibited previous to their sale, she went to the Pourtalès gallery with Mr. Robert Browning, the poet. Together they stood before this picture.

"That is my ideal of Roland who to the dark tower came," said Mr. Browning. They turned to the catalogue and lo! they saw inscribed the name of Roland. Strange that a great painter and a great poet, divided by nearly three hundred years, 
had had the same ideal of the peerless knight of the Chanson de Roland.

Velazquez died in $\mathrm{I} 660$. He had been appointed to a very onerous and a very prosaic post-that of "quartermaster and purveyor to his Majesty." Wherever the King travelled the painter henceforth travelled too, supervising the commissariat for the royal table. In the beginning of I66o King Philip IV. accompanied his daughter, the Infanta, when she set forth to meet her bridegroom, the French King, Louis XIV. Velazquez went too, saw that all arrangements were on a magnificent scale for the meeting of the two sovereigns. The work and anxiety were too much for him, and he caught the seeds of the fever that was to kill him. $\mathrm{He}$ sickened immediately on his return and died shortly after. His wife followed him to the grave within a week. The sun of her life had set, and she turned her face to the wall and died.

Bartholomé Estiban Murillo (I618-1682). Born in a humble condition of life, Murillo passed an unhappy boyhood. A relation who knew something of painting gave the lad some instruction in art, but, dying shortly after, left him without guidance. Still Murillo painted. He covered small bits of wood and of canvas with representations of the Madonna. He sold these by dozens to the captains of American ships, who sold them again to the recently converted Mexicans and Peruvians. He was twenty-four years of age when his imagination was fired by the sight of the painter Moya's copies of Van Dyck. Murillo made up his mind to study in some centre of art, 
and he set off for Madrid. There he found Velazquez at the height of his fame, and he was received by him with infinite kindness. Everything succeeded with Murillo. He got lessons, protection, admittance to the royal palace; he was helped by Velazquez in every way. When he returned to Seville two years later he was an accomplished painter. He took his native town by storm when he exhibited three little pictures illustrating the life of St. Francis. No one had noticed Murillo's absence until his return. He had left an obscure member of society, he returned famous.

From that time he scarcely left Seville till the day of his death. For thirty-seven years he painted, not always doing himself justice, for he was loaded with commissions, and his many-sided industry impelled him to accept everything that was offered. He had married a lady of fortune, and his home had become a favourite resort of fashion and art.

The picturesqueness of low life attracted him, and his studies of beggar boys are to be met with in every gallery-ragged and happy urchins laughing in the sunshine. The glory of the Madonna worshipped by angels entranced him, and his pictures of her Assumption are the glory of many galleries. In the Louvre is one for which the government gave over $£ 23,000$. The infinite pathos of the child Christ moved his soul. He was profoundly religious, and he would pray for long hours in his parish church. Murillo is a most popular painter, but he is unequal, and many of his pictures are overcharged with sentiment. All, however, are full of the glow of 
adoration. He died of a fall from a ladder while he was painting a large altarpiece at Cadiz. During his fatal illness he used to be brought every day to the church to spend hours in prayer.

There are many pictures in the National Gallery very characteristic of his genius. "St. John and the Lamb" (I76) is a charming work, very popular with copyists. A brown curly-haired boy is clasping a lamb, holding his head against its side. In "A Holy Family" (I3) there is a melting softness in the fusion of tones. The composition is rather stagey, but there is a captivating sweetness in the face of the divine Child. The chubby angels above are luminously painted. St. Joseph and the Virgin below are rather set in their pose. We have a "Spanish Peasant Boy" (74). He laughs in his rags, and his laugh has all the gladsome carelessness of childish merriment.

After Murillo the glory of the art of Spain set. Velazque $z$ and he died without leaving a rival behind. Long years passed before another artist, Goya (I746-I828), arose. He had no teacher and he had no pupil. Very distantly he resembles the incomparable Velazquez. There is a certain coarseness in his choice of subjects; his portraits are the best things he has done. He has a kind of wit and much brilliancy of execution. We have "The Portrait of a Spanish Lady" (I473) in pink satin covered with black lace. It is full of vivacity, full also of a sense of beauty and of character. The portrait "Dr. Peral" (I95I) is also remarkable for its delicate grey tones and for the life in the face. 


\section{CHAPTER XXI}

\section{ART OF THE LOW COUNTRIES}

"They sit there in the shadow and shine

Of the flickering fire of the winter night,

Figures in colour and design

Like those by Rembrandt of the Rhine, Half darkness and half light."

THE art of the North is that of Protestantism, Catholicism is that of the South. This is the first impression borne in upon us by a quick survey of the rooms devoted to the art of the Netherlands and of Germany. The delight in life that is so marked in the Italian school has given way to a sterner, more prosaic, more realistic ideal. The traditions of a classic past, deeply rooted in the beautiful land where nature is so kindly, have no hold on these other lands where the conditions of life are hard and strenuous. In Italy the Catholic Church preserved the traditions of saints and rules the life of the people. In the fifteenth century the Reformation swept over Europe and divided the continent into two opposing camps of faith, the Catholic and the Protestant. The northern countries declared for the Protestant faith. The Madonna was no longer the presiding inspiration of genius there, the legends of saints no longer furnished the theme of northern painter's dreams. Art patronage became secular instead of ecclesiastical. 
Portraiture, landscape-painting, genre-paintingand by genre-painting I mean the painting which takes its subjects from the small incidents of everyday life-these have replaced the old ideals. Instead of altarpieces we have great portrait groups of the members of guilds and corporations. Early portraiture was very faithful. Every wrinkle, every line was set down.

Protestant art has ever been the art of the people, and realism is the note of this art. The brothers Hubert and Jan Van Eyck were the chief exponents of realism. They were born at Eyck-sur-Meuse, and they lived and died there. If not the first inventors of the modern process of oil-painting, they brought it to perfection, and, above all, they brought it into common use. Up to this time tempera was the usual medium for painting. Tempera consisted of grinding the colours with chalk and laying them on with water, with white of egg, with size, or the juice of unripe figs. Damp was the chief enemy of tempera. The Italian artists had tried to mix their colours with oil and the result had been unsatisfactory, for the great objection to the use of oil was the long time it took to dry. The brothers Van Eyck understood chemistry, and they did not rest in their experiments until they had discovered a medium which hastened the drying and did not involve the necessity of exposing the colours to the sun. Nowadays we mix our colours with an oil medium, and we varnish them when the picture is finished. By the Van Eyck's method the varnish was incorporated with the surface colours. 
Look at this wonderful painting by Jan Van Eyck (I390-I440); it is the portrait of Jan Arnolfini and his wife (I86). They stand in a room that is a model of elegant neatness. She is dressed in the rich and ample garments that were the fashion of the day; her gaunt husband, holding her hand, stands beside her. He looks somewhat of a caricature with his big hat drawn down to his ears, his fur-bordered tunic from under which peep his thin legs and slippered feet. His right hand is raised. We feel that this worthy couple looked just as they do in this picture when they stood for Jan Van Eyck more than four hundred years ago. He painted them with relentless fidelity.

See how perfectly the colours are preserved, how fresh is the green of the woman's immense mantlefresh as if it had been painted yesterday. Jan Van Eyck knew the nature of every colour, how one colour affects the others. Sir Joshua Reynolds and Turner did not know chemistry as applied to painting, or they were in too great a hurry to obtain their effects. Their colours darken and crack; we can guess only at the first glow of their pictures. Those of Van Eyck appear as they looked when they left the easel. How marvellous also is the minuteness of the details. See the circular mirror behind the husband and wife, with scenes of the Passion let into its frame. Every object in the room is reflected therein-the oranges on the window sill, the slippers on the floor; two additional figures in a room beyond are seen through an open door. A branch brass chandelier hangs from the ceiling; this chandelier still exists. At the 
woman's feet in the foreground is a poodle. The whole picture is a page of the intimate, orderly, religious life of the time. Above is the signature of the artist, which, in its ornamentation and its clearness, is a work of art. "As I can, not as I would," is the motto inscribed-the motto that resumes all Van Eyck's hopes and aims. By the side of this great picture is a small portrait believed to be that of Jan Van Eyck himself. It shows a middle-aged man with a red kerchief wound round his head, and it is painted with unequalled strength, truthfulness, and minuteness.

Gerard David (I450-I523) was a painter of exalted and religious feeling. "A Canon and his Patron Saints" (I045) is full of fervour, but I think his most typical picture is "The Mystic Marriage of St. Catherine" (I432)-a theme often chosen by painters of the Middle Ages. This picture shows a walled garden, beyond which we see the buildings of a town. The Virgin is seated on a throne, the infant Christ is on her knee; He bends forward to place a ring on St. Catherine's finger. On the right is seated St. Barbara holding an open book, and St. Mary Magdalene with the vase of precious ointment in her lap. As is usual in these pictures, we see the donor, Canon Richard Van der Capelle, accompanied by his greyhound, kneeling before the Madonna and the Child. Every detail in the picture is carried out with marvellous care, and through every detail breathes the religious genius of the painter.

His contemporary was Mabuse (I470-I54I), a 
most conscientious painter, whose elaborate finish and brilliant colouring are very noticeable in all his works $(656,946$, I689). This latter picture, "Portrait of a Man and his Wife," is quite a masterpiece of finished detail and of breadth of effect. There are many portraits by him, and, although Mabuse was not equal to the best painters of his time, we must note the high perfection of finish in all his pictures.

Quentin Massys (before I460-I530) was perhaps the greatest Belgian painter of his time. He raised the school of Antwerp to a higher level than that of any other Flemish school. He is usually called the smith of Antwerp, because he began life as a blacksmith. He gave up this profession to take up art, for which he had shown signs of genius almost from childhood. He had little feeling for real beauty of form, but he had an earnestness, a tenderness, and a clearness of colouring that redeemed all his faults. The one picture that we have by him in the National Gallery is the "Salvator Mundi and the Virgin Mary" (295). The colouring of the Christ is somewhat heavy, but there is so much delicacy of feeling, so much expression that it ranks among the masterpieces we possess.

Roger Van der Weyden (I400-I464) some say was a pupil of Jan Van Eyck, but very little is known about him. That he was a native of Tournay, that he was deeply religious, that he visited Italy, that he wielded a great influence over the early Flemish school, and that Memling was his pupil is about all that we know about Van der Weyden. 
The three pictures in the National Gallery $(664$, 7II, 7I2) show the intensity of his faith. The two last are heads and hands of the Madonna and of Christ on a gold background.

"Husband and Wife" (653), sometimes called "The Painter and his Wife," is often ascribed to Roger Van der Weyden, but now is generally held to be by a member of his school. The man has a resolute and serious face, "the woman is sweet and motherly." I should like to think it is a portrait of Van der Weyden and his wife, but it is doubtful.

"A Reading Magdalen" (654) belongs to the school of Van der Weyden; it is believed to be by one of his pupils. The Magdalen is dressed in the cumbrous draperies of the time. I cannot imagine how women walked thus attired. Her hair is gathered under a heavy coif, and she is reading; at her feet lies the alabaster box of ointment. Her face is plain, but there is in it so much sweetness, so much absorption in her study that it attracts the beholder.

There are a great many legendary records concerning Memling, the painter of Bruges. One of the most charming tells that, at the Battle of Nancy in I477, where Count Charles the Bold lost his life, a wounded soldier was brought into the Hospital of St. John at Bruges. His name was Memling. He had been a painter before he became a soldier; during his long convalescence love for his art returned, and there also returned the old enthusiasm for religion. Tradition says he loved the young 
nun who spent her days nursing the sick and who used to sing and pray in the chapel. The soldier recovered from his wounds and he took to painting once more. He painted the marvellous pictures that are still in the Hospital of St. John and that are the treasures of the place. The reliquary of St. Ursula is among them. It is a shrine about four feet in length. On one of its gable ends is a painting of the Madonna and Child with two of the sisters of the order kneeling before them. On the other is the picture of St. Ursula with the arrows that were the instrument of her martyrdom and the Virgins hiding under her mantle. There are medallions of Ursula painted on the ceiling of the shrine, showing the saint leading up to heaven a procession of maidens martyred with her. I can imagine the young nun Memling loved inspiring his work, and being the unconscious model from which he painted. Through the picture "The Virgin and Infant Christ enthroned in a Garden " (686) breathes the spirit of Memling's art. The figures are seated in a peaceful enclosure. Oh, how serene is the light that shines over the alleys! The Virgin has an angular charm of her own with her high arched eyebrows, her lofty brow, her beautiful slim figure, her long hair, and her mild eyes under drooping lids. On her right is an angel playing a guitar, on her left is St. George trampling under his feet the dragon which symbolises sin. In the front is the donor of the picture kneeling to the divine Infant, who is turning over the pages of a book His mother is holding while $\mathrm{He}$ 
ART OF THE LOW COUNTRIES

listens to the angelic music. It is a picture that sets us dreaming and thinking of that wonderful story. There are two other pictures by. Memling $(709,747)$. His landscape backgrounds are always very clear, and are peaceful, as was his soul. 


\section{CHAPTER XXII}

\section{A GREAT TRIO}

"There are dreams that cannot die."

Contrasting with the art of Memling is that of Rubens. Rubens is pre-eminently the naturalist painter (I577-I640). There is little trace of the ideal inspiring his work, yet his genius was so stupendous that it cast a radiance over the whole Flemish school. He was born at Siegen in Westphalia, where his father had been exiled for political offences and for his adherence to Protestantism. The boy got a splendid education, and his talents enabled him to assimilate all he learned. He lost his father when he was ten years of age, passed his childhood at Cologne, then returned with his mother to Antwerp. He was very handsome, very cultivated, very charming. His love of work was so great and his imagination so fertile that the number of his pictures is astonishing. His first teacher in art was Adam van Noort, illustrious as a colourist. Before four years had elapsed the pupil had excelled his master. He then studied under Otho Venius, a painter of no great attainment, but one who loved science, who was a mathematician, a historian, and a poet. He could 
not do much to train the genius of his pupil, but he helped to cultivate his mind. There was a gaiety about Rubens that early displayed itself in the brio of his brush work and the glow of his colour.

When he was twenty-one he was admitted into the Guild of Painters at Antwerp. Two years later he left Holland and went straight to Venice, and there his charm, his handsomeness, his cultivated manners won friends for him. He received recognition almost from the first from the princes of Italy. $\mathrm{He}$ was a man who found delight in this world, in its beauty, its form and colour. All life came easily to him. Later, when he went to England, he enjoyed the friendship of Charles I. Raphael himself was not more honoured than was Rubens. He was the confidant of sovereigns; sometimes he dabbled in politics. He was charged with a secret mission from Philip IV. of Spain to our Charles I. in I629. During his visit to the King of England he was one day copying a Venus by Titian. One of the courtiers, who only knew him as an envoy of the King of Spain, discovered him at his easel.

"Does the ambassador of his Catholic Majesty sometimes amuse himself with painting ?" he asked. "I amuse myself sometimes with being ambassador," retorted Rubens.

He was a man of power, holding his life lightly as becomes a master.

His exuberant vitality made him prefer painting big pictures to little ones, for no undertaking, however difficult, surpassed his courage, yet he has painted small pictures that are lovely in the care 
with which they are finished. We should have to travel over Europe visiting the galleries before we could have an idea of all that Rubens has done. Let us look at some of the pictures in our National Gallery.

"The Abduction of the Sabine Women" (38). You know the story of how Romulus, the founder of Rome, wanted wives for his soldiers and resolved to get them by stratagem. So he appointed a day for a splendid sacrifice. Thither came the neighbouring Sabines with their wives and daughters, and, at a given signal by Romulus, the Romans with a shout rushed on the daughters of the Sabines and carried them off. The moment chosen is when the signal is given and the throng of men and women are fighting and struggling together. Rubens' women are not Roman, but Flemish women dressed in the costume of the seventeenth century. It is a rough scene, instinct with vitality, the occasion for superb colour, for wonderful drawing. It is a gay and brilliant rendering of a barbaric episode. Then if we turn to "The Judgment of Paris" (I94) we see a landscape flooded with afternoon sunlight. Three women are standing, three goddesses-Venus, Minerva, and Juno. They are contending for the apple that Discord has offered to the most beautiful. Paris, the son of Priam, who is feeding his flocks, is to be the judge. By his side is Mercury. Paris is about to hold out the apple to Venus, a fair-haired opulently formed woman. Under a tree stands Minerva, an owl seated on a branch above. To the right of Venus is the stately Juno with the 
peacock at her feet. The subject is a legend of Greek mythology, but Rubens has treated it most realistically. The women are three Flemish women and are no goddesses of Greece. The landscape is very beautiful, full of sunshine, and fresh with an open-air feeling. It is Venetian in its golden hue, in its unclouded brightness.

I wish I could show you some children painted by Rubens-mischievous, animated little creatures, instinct with life from the tips of their toes to the crown of their curly heads, but I have time only to cast a rapid glance at a portrait, "Le Chapeau de Paille" (852). This portrait is a wonder of painting. It is that of Rubens' sister-in-law, Susanne Fourment. Her hands are crossed; she looks out of the canvas with an alluring expression. A transparent shadow is cast by her hat over the upper part of her face. Rubens had been twice married. He was happy in each union, but he was most happy in the second. His wife, the beautiful Helena, was his ideal type of beauty. He was constantly painting her, and her portrait is to be found in many galleries. This incomparable painter died aged sixty-four, possessed of immense wealth.

Van Dyck (I599-I64I) was born at Antwerp; he was the son of a simple tradesman. When he was little more than ten years of age he became the pupil of Hendrik van Balen. His real teacher, however, was Rubens, with whom he lived four years. By this master's advice he visited Italy in I623, staying at Venice and Rome; his longest sojourn was at Genoa. He then returned to Antwerp, 
and his fame spread as a portraitist. The wealthy and titled flocked to be painted by him.

$\mathrm{He}$ twice visited England, in 1620 and 1627 , and finally he settled there in 1632 in the service of Charles I. The English king delighted to do honour to Van Dyck's genius. He gave him a pension of $£ 200$ a year, knighted him, and appointed him court painter. The lords and ladies followed the royal example, and Van Dyck painted the whole society of the time. Himself, a cavalier in sympathy, he was the painter of cavaliers. We know these gallant men with their long ringlets, their heavy plumed hats, their wonderful silken coats. We know the sweet and remote court ladies with their slender white hands and their air of unconscious god-like superiority.

Van Dyck was devoted to the King. Let us look at the equestrian portrait of Charles I. (II 72 ), one of the finest equestrian portraits ever painted. The artist is a courtier and his king is his ideal. Charles I. is riding past on a dun-coloured horse, carrying a marshal's baton, dressed in armour; his refined melancholy countenance is very abstracted in expression. The nobility of his carriage, the elegance of his figure, the sadness and beauty of his face make us understand the spell he has cast over the nation. He is gazing in front of him, seeing nothing around him. We know that he is riding to his death. We forget his faults; we only remember his kingly grace and his unhappy fate.

A portrait of less alluring charm but of splendid quality is that of Gevartius, now called the portrait 


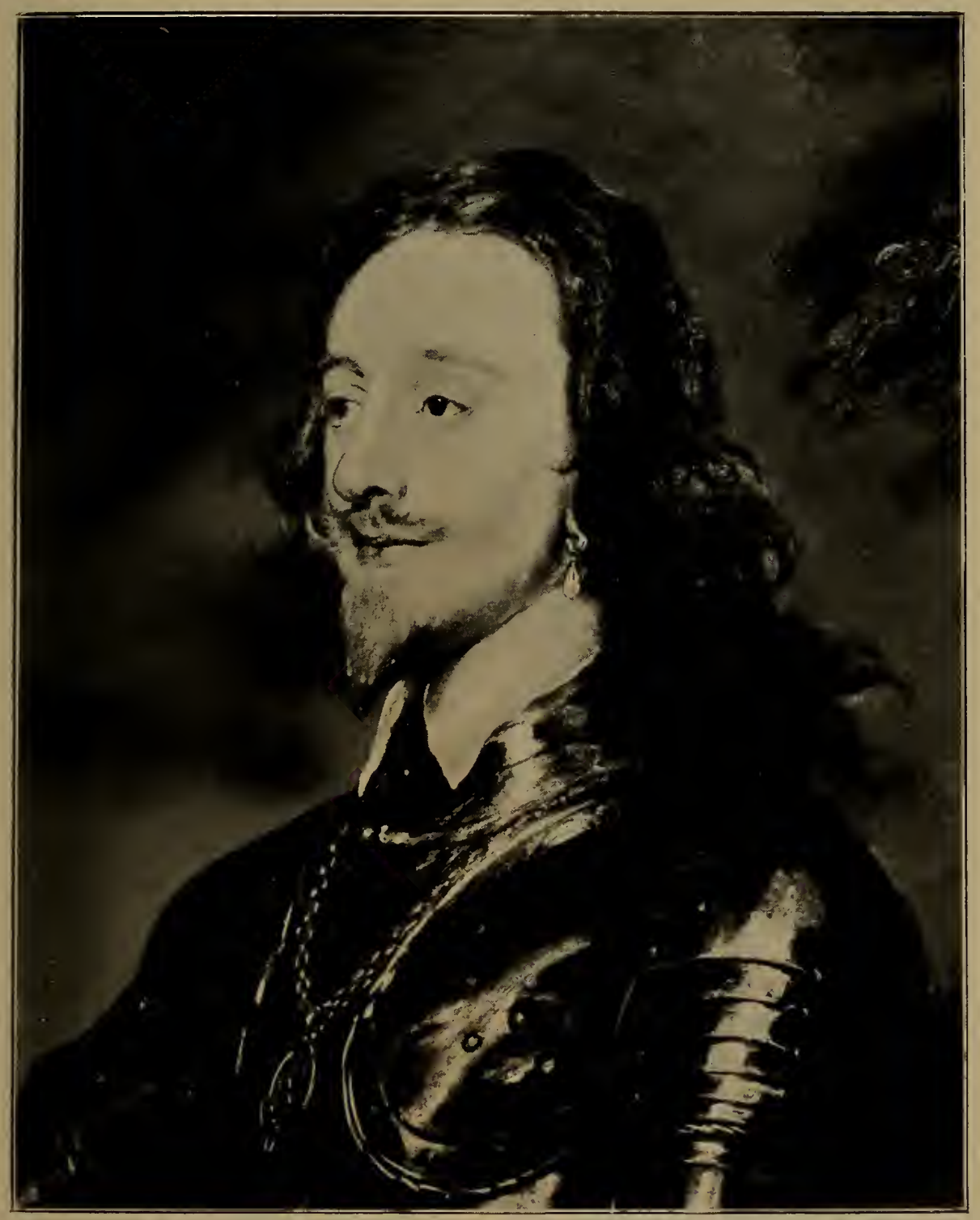

"HEAD OF CHARLES I" (FROM 1172) BY SIR ANTHONY VAN DYCK 

of Cornelius van der Geest (52). It is the magnificent rendering of a grave and noble countenance. Van Dyck considered it one of his finest works; he would carry it about with him as a specimen of what he could do. Our Gallery does not possess any portrait of the fair women and distinguished children in which he used to excel.

Van Dyck lived in great style. He was always magnificently dressed. He was the adored portrait painter of an age whose romance he has preserved, whose men and women he has endowed with immortal youth, round the head of whose ill-fated king he has placed a halo. The misfortunes gathering round the sovereign and the royal family weighed upon the painter. He spent two years travelling with his young wife, the granddaughter of Lord Ruthven, but the depression gained upon him. Illness overtook him and he died at the age of forty-two.

One more great painter of the Flemish school remains to be noticed-David Teniers. He flourished between I6Io and I690, and he was the first genre painter of Belgium. He was very prolific. "To contain all my works," he would say in his pleasant voice, "would take a gallery two leagues long." He painted every detail. A famous French painter used to say, "Show me a pipe and I will tell you if the smoker is by Teniers or not." He became rich and celebrated, and entertained the most select society of the Netherlands in his castle of Trois Tours at Perck, between Antwerp and Malines. His wife was Velvet Brughel, the ward of Rubens. 
He loved to represent feasts, village dances, the interior of country inns, laboratories, shops, and kitchens, and he represented all with spirit and gaiety. "A Music Party" (I54) shows us his charming genius. He also painted with heartbreaking sadness the horrors of war. We find his pictures everywhere-in Russia, in Spain, in his native country, in Italy, in France, and here in England.

"A Game of Backgammon" (242) is very characteristic of Teniers. Look at the eager attitude of the old man bending forward to watch the throw of the dice as the others look on. There is a pot of beer beautifully painted by the side of the bench, and, in the background, we see mine host warming his back at the fire and talking. He has turned to look at one of the rustics, who evidently has drunk too much and is falling asleep. Every detail is painted with Teniers' brilliant touch. Its ease, its force, its gaiety is quite unparalleled. These pictures represent the joy of life. There is no religion in Teniers' inspiration, there may be no idealism. They show the jollity of existence without care, with no thought for the morrow.

Mr. Ruskin has called Teniers the painter of the pot-house; this seems too severe a definition of the man who had such rare artistic qualities. $\mathrm{He}$ arranged his groups so picturesquely, he had such exquisite harmony of colouring, so much sparkle in his touch. The charm and value of his pictures lie in their sincerity. We feel as we look at them that he saw what he painted. His boors, his 
soldiers, his plain folk are all alive. He did not strive much for the ideal. His people as a rule are not very pleasant to look at, but the beauty of his execution cannot be overlooked. "The Village Fête" (952) is remarkable for its colouring, its arrangement, for the spirit and gaiety of the painting. There are several pictures by Teniers in the National Gallery. You must look at them all and look at his landscapes, for they are silvery in tone and full of a delicate feeling for nature. 


\section{CHAPTER XXIII}

DUTCH ART-ITS RISING AND I'TS SETTING SUN

"How fair a lot to fill

Is left to each man still."

VAN Dyck's contemporary in Holland was Frans Hals of Haarlem, born about I 58I, died I666. With this painter begins the century of great art in Holland, a century that closed suddenly and completely with the death of Rembrandt. It was the Renaissance of Holland, the time immediately following her liberation from the shackles of Spain. She feared no more the terrors of the Inquisition, she shook herself free from Catholicism, and in her new-found liberty she opened wide her doors and became an asylum for the boldest thinkers. She founded a national school of painting. All the great painters of the Dutch school flourished between I 584 and I683, the year of the birth of Van Huysen. Frans Hals, whose portraits have the look of arrested life, began the school. Rembrandt, the magician, whose wand was light, closed it.

Frans Hals was the merriest, the most clearsighted of all the Dutch portrait painters. The stroke of his brush was swift and sure, his colour was brilliant; he moulded his faces in light. He is very poorly represented in our National Gallery;

$$
{ }_{138}
$$


there are but two heads by him-the "Portrait of a Woman" (IO2I), which is not at all characteristic of his free, jovial, and vigorous method, and "Portrait of a Man" (I25I). I want you to look at this portrait. The original is a man of about forty years of age. He wears a simple satin doublet and an ample ruffle round his neck; his face is kindly, scrutinising, slightly amused. It is a strong, thoughtful countenance, full of good sense and of life. In all Hals' portraits you will see the same animation, the same splendid spontaneity. None of his people seem to be posing for a likeness.

Frans Hals was the rising sun, Rembrandt the setting of the new era. Many are the painters grouped about these two supreme artists. I shall first speak to you of Rembrandt van Rhyn, thus called because he was born on the banks of the Rhine, the poet painter of light and shade.

Born at Leyden in 1606 , he was the son of a miller. He was never book-learned: he possessed a Bible, Josephus (the great historian of the Jews), and Albert Dürer's book on proportion. In later life eight more volumes were added to his collection. You see he did not read much, but he studied life at first hand; he observed everything, and, most of all, he observed the play of light and shade in the dusky corners of his father's mill. $\mathrm{He}$ was a pupil of Lastman, a man of importance, but in truth he learned of no man; he taught himself everything. He simply worked patiently and passionately from morning to night. He had his models at hand-his father, his mother above all, whom he was always 
painting or drawing at work, at rest; every wrinkle of her face, every expression of her wise and patient eyes grew familiar to him. There was his sister Lizbeth; above all there was himself. Rembrandt's self portraits are extraordinarily numerous. We see him in youth when his face was still unlined, in his triumphant manhood when he surmounted every obstacle, in his weary old age after he had experienced disappointment and sorrow. These self portraits are the record of his life. He studied humanity first by studying himself.

In our National Gallery we possess Rembrandt $(672)$ in the flower of his life, aged thirty-two, a calm and purposeful man. $\mathrm{He}$ is dressed in rich velvet and heavy fur. We have Rembrandt aged sixty-three (22I). Years and suffering have lined his face, tears have furrowed his cheeks and dimmed his troubled eyes. A whole lifetime lies between these two portraits-between Rembrandt in the prime of his years and Rembrandt old and sorrowful. The tragedy of grief and disappointment, of desperate straits was enacted. Rembrandt was undone by his love of collecting. He loved beautiful things not wisely but too well-gems, armour, rich brocades, pictures, etchings, carved furniture; he was always buying them. So long as his wife, his beloved Saskia lived, he would purchase jewels and rare stuffs with which to deck her. She died, and, in his wretchedness and loneliness, he devoted himself more than ever to his art, and bought these things the loveliness of which entranced him, and the collecting of which was ultimately to prove his ruin. He has been called miserly; far from that he 
was extravagant. He had the artist's passion for beauty and he could not control his bent.

It is by his treatment of light and shade that Rembrandt gained immortality. It was a peculiar and personal treatment. He sought after effects that are beyond the range of colour to give, and which he strove to express by his management of light. In the British Museum you will find many marvellous etchings signed by him, and you must look at them all, seeking for that strong and subtle power of working in light and its attendant shade. There is one of "The Last Supper at Emmaus." Christ has broken the bread and given the wine to His two disciples, who still do not recognise Him, and as they look He vanishes; a great light alone tells where He has been.

In "The Adoration of the Shepherds" (47) you will see what I mean by Rembrandt's personal treatment. The scene is a dark stable, and all the illumination comes from the light emanating from the Child. That glorious light quenches all others ; a lantern held by one of the shepherds sends but a feeble ray, the kneeling figure in the foreground is in deep shadow. In Rembrandt's portraits he makes light and shade play a transfigurating part. There are several portraits in the National Gallery besides those I have mentioned (5I, I66, I90, 237 , $243,775,850,1674$, and I675). His portraits of old ladies are peculiarly touching. He had a great sympathy for age for his mother's sake, all its wrinkles are dear to him, pathetic eyes tell him a tale of wise prudence and tenderness. He died in poverty and loneliness in 1669 . 


\section{CHAPTER XXIV}

\section{DUTCH SCHOOL (Continued)}

\section{"Jack and Joan they think no ill,}

But loving live, and merry still ;

Do their week days' work and pray

Devoutly on the holy day."

REMBRANDT's influence was largely felt, and it was owing to him that the Dutch school became renowned for its striking and poetic treatment of light. It redeemed the commonplace; it touched with something of the ideal the household pots and pans; the implements and contents of the larderall the trifles that make up still life.

A group of painters, all more or less illustrious, gathered round Rembrandt and his great precursor Frans Hals. Portraits, pictures filled with the atmosphere of home life, marine scenes and landscapes depicting the beauties of their beloved country, such are the themes chosen by these painters.

Pieter de Hoogh (1630-1678) flooded his pictures with golden sunshine. $\mathrm{He}$ is the painter of pure light, and light gives the idealising touch. There are three pictures in the National Gallery by him, two of Dutch courtyards (794 and 835) and one (834) the interior of a Dutch house. These pictures 
are festivals of gem-like colour. All the homeloving life of Holland is in them. We see the zealous haus-frau standing in the courtyard waiting for her husband's return, we see him returning pushing open the garden gate. The interior of the Dutch house shows a tessellated floor all brilliant with light and shadow. It is a picture of well-to-do comfort. There is no spiritual ideality, but there is honest and beautiful workmanship and familiar delight.

I can only tell you of some of the artists that formed the group. There is Gabriel Metzu (I630I667), remarkable for the harmony of his colour. His pictures are often of music (838-839), suggesting pleasant memories in which music entered.

Van der Neer (I603-I677), the poet of night, is represented by several pictures, the most charming being (239). He painted moonlight romantically.

Nicholas Maas, pupil of Rembrandt (I632-I693), draws his figures most finely and spiritedly. Of the pictures by him in the Gallery "Card Players" (I247) is the most characteristic of his manner. See how the young girl's fingers are hovering over the cards she holds, hesitating which to play, and her partner is waiting for her decision, looking out of the canvas with an amused expression. (207) and (I59) are also excellent. Maas is a fine example of observation of ordinary life and a noble sense of colour.

Adrian van Ostade (I6IO-I685) was a pupil of Frans Hals. He is the painter of peasant life and rustic revels, the painter also of the necromancer's 
life. See the alchemist (846), a strong picture, showing the destitution of the man who is devoted to his quest for gold. His brother Isaac (I62Ir649) is the painter of winter, of frozen canals and skating (963).

Bartholemew Van der Helst (I6II-I670) was a portrait painter of most remarkable gifts; indeed we may say that he never attempted anything but portraits, for his great historical pictures in the museum of Amsterdam are simply a number of portraits in one frame. Sir Joshua Reynolds said of the picture at Amsterdam, "A Company of Civil Guards," that it is "perhaps the finest picture of portraits in the world." Here is a portrait of a young lady (1348), which is a specimen of his art. It is a realistic portrait; look at the expression in the dark grey eyes, at the beautiful painting of the hands, at the representation of the gold embroidery, of the fine lace collar and cuffs, at the lustre of pearls and jewels. There is nothing, however, of Rembrandt's concentration of light and of deep gloom in Van der Helst's works.

Molenaer, the two Mieris, Netscher, all belong to the group of painters flourishing between Frans Hals and Rembrandt.

Gerard Dou (I613-I675) was a direct pupil of Rembrandt; his work is quite microscopic. "The Poulterer's Shop" (825) is a marvel of high finish and breadth of execution. The shopwoman is holding up a pair of birds for the inspection of a customer; on the window sill is game of every description; every feather of the birds, every hair 
of the animals' hides are exquisitely depicted. In (I92) and (968) we have the portraits of this extraordinarily clever artist and his wife. The portraits are finely individualised; they are full of life and of expression.

Then there is Jan Steen (about I626-1679), the wittiest, most jovial of artists. The painter of tavern scenes, himself a brewer, who joined the profession of painter and publican; he was the least spiritual of artists. We see his rollicking rustics in every gallery-boors drinking, making love, clumsily dancing, sometimes fighting. With his observant eye he beheld many brawls, many discordant scenes, many joyful revels, and he painted them as he alone could paint. He had a great gaiety of brush. He has left a fine portrait of himself; it is that of a gentle, serious face, the very last we would associate with his genius and with his life. In the National Gallery is "The Music Master" (856), for often Jan Steen chose scenes of life from the wealthier classes; and the magnificence of the painting of this little picture is very remarkable.

We now come to Terborgh (I6I7-I68I). Let us look at his remarkable historical picture, "The Peace of Münster" (896), a peace that put an end to the terrible Thirty Years' War and proclaimed the independence of the Dutch united provinces in r648. This picture is one of the gems of our. national collection, every face therein is portrayed so strongly and is so well individualised. We seem to know the character, the very temperament of its owner. The delegate, in a red cloak, reads the 
clauses of the treaty, and the listeners are holding up their hands in sign of approval. The wonderful distribution of the light over all these faces, the dark gloom of the black draperies give a unity to the picture scene. Terborgh introduces his own portrait amongst those of the crowd; it is the third on the left behind the man whose hand is on the back of a chair. It is a scene of supreme interest. Terborgh himself was present at the great discussion, and he painted it at Münster during the congress. All the heads are portraits. During his lifetime Terborgh would not part from it.

There is a story of dramatic interest attached to this picture. It belonged to Prince Demidoff. When the prince died his pictures were put up for sale, and the Marquis of Hertford became the possessor of "The Peace of Münster." Lord Londonderry had tried to get it for England; he had offered eight thousand pounds, and he could do no more. In due time the Marquis of Hertford died, and Sir Richard Wallace inherited his gallery.

One day the keeper of the National Gallery was told that a gentleman wished to see him. It was a busy morning; however, on the promise that the interview would last but a few moments, a stranger bearing a parcel was admitted. He began to explain the object of his visit, but the official cut him short, bidding him leave the picture behind and he would hear tidings of it within a week. For all answer the stranger began to undo the straps round the parcel; the official tied them up again, impatiently 
repeating what he had just said. Then the visitor said: "My name is Sir Richard Wallace, and this is the 'Peace of Münster' by Terborgh. I wish to present it to the National Gallery."

You can well believe how the keeper was thunderstruck.

Terborgh excelled in another class of pictures, of which "The Guitar Lesson" (864) is an example. It shows how music was part of the home life in that northern country, and it displays the master's certain and delicate touch.

In marine painting we have Van de Velde, the younger, who was born in 1633 and died in I707. He has been called the most famous marine painter of Holland. He lived for a large part of his life at Greenwich in the service of Charles II. and of James II. ; they granted him and his father a pension of $£$ Ioo per annum. His father was an eminent draughtsman, whom the English king paid to make drawings of sea-fights, and he paid the son to put these draughts into colours. Both artists were specially commissioned by the East India Company to paint several of their ships. It was in Holland that marine painting first played an important part. The sea was the glory and the menace of this low lying country. We prefer Van de Velde's calm seas where the boats are at anchor to his boisterous ones. The "Calm at Sea" (874) is painted like a miniature; the transparent light, the delicacy of the tone I want you to notice.

We will now pass on to Bakhuizen (163I-I708), the painter of wrecks and storms. The artist is 
said to have often exposed his life for the sake of studying the effects of cloud and wind. We have five of his pictures; they are hard and they lack transparency of colour, but they are full of movement. Bakhuizen was very much patronised by sovereigns. It is good to study them, for they show the state of marine painting in Holland. Peter the Great frequently visited his studio and even took lessons from him. "Dutch Shipping" (223) is a good example of his work.

Then there are the landscapes of the Dutch school. The Dutch set themselves to reproduce the physical features of their country with love and great technical skill. We meet constantly avenues of poplars, wide plains, sluggish canals. Albert Cuyp (I620-I69I) was before all things the painter of light. We, in England, call him the Dutch Claude. His golden skies over a misty land, or over calm waters, are delightful to contemplate. Whether Cuyp paints a river scene where ships are leisurely sailing, as in (823), or whether, as in (53), he paints a landscape with cattle and figures, he is always individual. These pictures are all gold and silver haze. In (53) a rider in a coat of brilliant vermilion, somewhat out of keeping with the tone of the landscape, mounted on a horse of dapple grey, is talking to a pretty shepherdess guarding her flocks. It is an idyllic scene. The light, the sky, the misty haze are tender and suggestive. Ruskin says hard things of Cuyp, but he also tells us that Turner owed much to him. He loved the mellow light of evening rather than the garish light of early after- 
noon, and almost all his pictures in the National Gallery are harmonies in gold.

Paul Potter is a painter of cattle first and of landscape merely as a background. What a painter and what a workerwas Paul Potter (1625-I654) during his twenty-nine years of life. He was born at Amsterdam, and he was an accomplished artist at fifteen years of age. He died, some say of consumption, others of over-work. I can't tell you much about him, for my limit is coming to an end. His aim was truth ; he thought of nothing but representing faithfully what he saw. He was a painter of the dear dumb animals. We see them in his pictures standing knee deep in the flowery fields, generally in the spring time. We possess but two pictures by him. "Landscape with Cattle" (849) brings all nature to us, and "An Old Grey Hunter" (I0o9), a portrait of a horse, a fine example of his style. His "Young Bull" at Amsterdam is a marvel of life; it is a huge picture; the bull is life-sized.

And now we come to one who might be called the king of landscape painters-Jacob Ruysdael (I628-I682). The son of a picture dealer, he quitted medicine for art and he never married. At heart a solitary, he sought the silence, the mystery of nature. $\mathrm{He}$ painted storms as they have never been painted. There is the picture of one at the Louvre which a great French critic calls the "prodigy of the Louvre." The sense of a turbulent influence seemed to possess him, and he would render the sadness of many effects. He was inspired by solitude, by the roar of falling water, by the 
jagged rocks. Woods of pines and beeches were his favourite haunts, torrents and waterfalls his favourite subjects. In "A Landscape with Waterfall" (627) (and there are three pictures (628 and 737) that bear that title), we seem to hear the dash of the spray among the rocks and to see the brilliancy of the white clouds against the dark trees. So dearly were trees associated with the life of this unmarried man that he would often paint the portrait of a single tree. In "An Old Oak" (988) and "The Broken Tree" (99I) we have pathetic examples of this love of the leafy monarchs. He painted many northern scenes from sketches made in Norway by a friend. He died in $\mathrm{I} 682$ in an almshouse close to where Rembrandt had lived.

Meindert Hobbema (I638-I709) is Ruysdael's only rival, and he was his pupil and friend. But Hobbema loved the blithe side of nature. His trees glitter in the sunshine, his skies are wind swept, and in them great white clouds gather. "The Avenue, Middelharnis, Holland" (830) remains in our memory. It is so imbued with the sense of homeliness, which is the endearing charm of these Dutch pictures. We feel that Hobbema must often have walked down that long avenue under those tall lopped trees, that he must often have looked at the ditches on either side dividing the neat plantations trim as a lawn, from the road, and seen the nursery garden on the left in which the gardener is at work. The road leads to the village, and we like to think of Hobbema frequenting the village church peeping from the trees to 


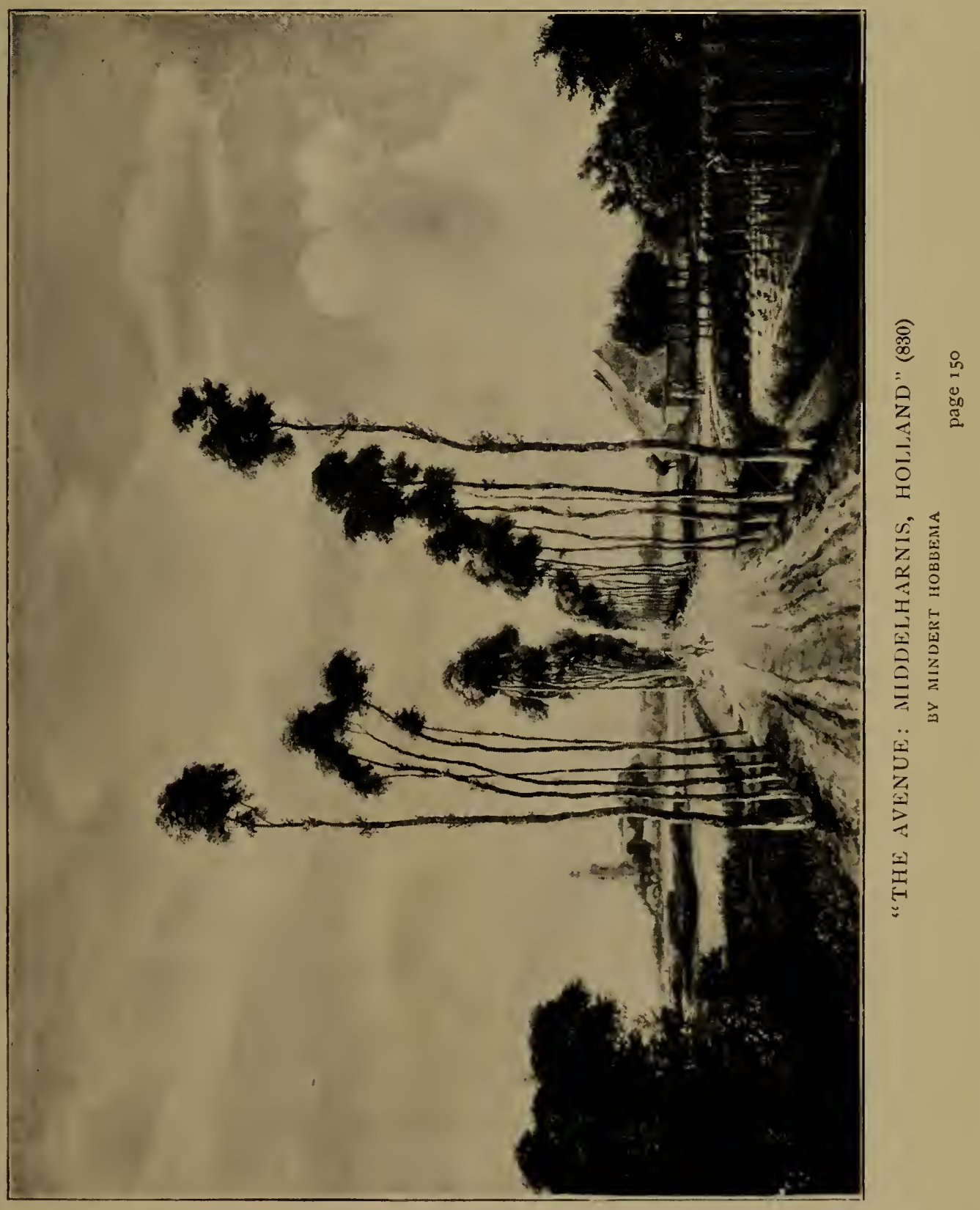


the left; those red-roofed cottages we feel were familiar to him. The beautiful white clouds of fantastic shapes congregating above are very characteristic of his love of summer skies. Other pictures by the same artist are in the Gallery. $\mathrm{He}$ was not appreciated by his country folk, and he died in great poverty in the street where Rembrandt had died just as poor four years before.

We must not forget the golden landscapes of Jan and Andrea Both (I6IO-I652). The brothers were models of fraternal affection: they travelled together, worked together, and I was about to say they died together, for Jan died of grief when Andrea was drowned in one of the canals of Venice. Andrea was a good painter, yet he cared only to paint the figures in Jan's landscapes. These landscapes are charming, but there is something artificial about them in their glowing skies, their feathery trees. The brothers Both were among those who italianised the Dutch landscape. To look at one of their pictures is to look at all. "Landscape: a Party of Muleteers with Laden Mules : Morning" ( $7 \mathrm{I})$, with its mountain scenery, its rocky foreground, with the lake in the middle distance and blue mountains beyond, is very like "An Italian Landscape" (I9I7), where there are groups of trees with distant mountains seen in a glowing sunset, where peasants on horseback and two men are grouped by the roadside in charge of some goats, and two craggy cliffs close in the picture and the landscape beyond.

Jan Wynants (about I620-I679) was the first of 
the school of real Dutch landscape painters. He sought his inspiration from Holland and Holland alone. He is the very reverse of Ruysdael; he has no sympathy for gloom or solitude, he cares only for sunshiny scenes, for sandbanks that glow in the light of summer skies, or for the wooded borders of the great forest. Look at the two "Landscapes with Figures" (884, 97I). They are excellent examples of Wynants' art. There are other landscapes by him in the National Gallery, and in almost all you will see a sand-hill or a sandy road gleaming golden. The figures in his landscapes were put in by other artists. It often happens in Dutch pictures that the landscapes are by one artist and the figures by another. Andrian Van De Velde was probably Wynants' assistant.

Wouwerman (I6I9-I668), " of the White Horse," as he is called, for in almost all his pictures a white horse is the central object that focusses the light. He was a very prolific painter; his pictures are full of movement, and his figures and animals are skilfully drawn, and yet they do not move us. We remain cold before scenes that should harrow us. It is all too orderly, too smooth, too neat. We cannot imagine "A Battle, Cavalry and Infantry" $(976)$ conducted on so orderly a pattern.

Sir Peter Lely (I6I 8-I680) was a native of Holland ; he settled in England in I64I. He came in the suite of William of Orange, son-in-law of King Charles I. It was the year after Van Dyck's death; upon this master Lely modelled his style. He began by painting Cromwell, who commanded him to paint 
warts and all. Then when Charles II. succeeded as king, he became a royal favourite. He painted all the frail beauties of the court. You will see them all at Hampton Court. It was a lucrative business. "Lely is a mighty proud man," says Pepys. As he was painting the Duchess of Somerset in I680 he was struck down with apoplexy. A portrait (IOI6) of a girl feeding her parrot with cherries is the single specimen here of Sir Peter Lely's work. 'It is somewhat artificial, and yet there is in it a decided sense of beauty.

We must not forget Van Huysum (I682-I769), the painter of flowers, of birds' nests with eggs in them. Look at "A Vase with Flowers" (796 and IOOI). They are full of charm and grace. Then there are two painters of still life, Jan Weenix (I62I-I66I) and his son (I640-I7I9). They painted with great spirit hares, pheasants, wonderful fruit, vegetables, and the imitation is so perfect that in their pictures "life," it was said, "seemed restored to the dead creatures."

Snyders (I579-I652) was a friend of Rubens and a native of Antwerp. His parents were the proprietors of a large eating-house, and Snyders had plenty of opportunity of seeing dead game, fish, fruit, and vegetables, and he enhanced the brilliancy of his groups by introducing some gorgeously plumed parrot or bird. See his fine picture, "A Fruit Piece" (I252). Rubens often helped him, and Snyders groups are very valuable now.

I have told you enough I think of these Dutch painters. There are many other things, but I must 
hurry on to other schools. I want you to remember always that light and shade are the magic of the Dutch, that with them they wrought superb and glowing effects. The love of the Dutch for their Holland inspired their art; all the simple ideals of life were dwelt upon by them with special love. It is this affection for home, for the skies and roads of their native land, for the plain and humble people who were their kinsfolk, for their delight in music, in the amusements-often the boisterous ones of daily life-that are expressed in their art and make it so interesting to us. We feel that nothing is really common to these Dutch painters, that observation and sympathy touch all things and lift their representation to the rank of high art. 


\section{CHAPTER XXV}

THE GERMAN SCHOOL

"Here, where art was still religion,

With a simple, reverent heart, Lived and laboured Albrecht Diurer,

The evangelist of art."

Two supreme masters cast a glory over the German school-Albert Dürer and Holbein. Dürer is a far more typical German than is Holbein. $\mathrm{He}$ was very much impressed with the Lutheran teaching, and pure and high ideals moulded his art and moulded his character. Holbein was a complete contrast to him. He was not prone to theories; he was not steeped in speculation; he did not dream as did Dürer of mysteries in heaven and earth; he had no passion, but he was full of joyous fancies. A less powerful personality than Dürer, Holbein was a far superior painter. From the unfathomable mind of Dürer came strong thoughts. He has expressed them in his art, especially in his wood engravings. One is a knight riding out, pressing onwards, looking neither to the right nor to the left, surrounded by the foul fiend and the terrors of death. His cheek does not blanch, his eyes do not wander, he keeps gazing straight before him. Another is Melancholia-a strange woman ponder- 
ing over the secrets of life and death. These two woodcuts express all Dürer's soul.

Of Dürer we know something from his own journal. He lets us into his life. We know that his father was a goldsmith, that he was born at Nuremburg (I47I), and that his master was Michel Wolgemut, an artist who is unrepresented in the National Gallery. Dürer was the intimate friend of the fiery Luther, the gentle Melancton, the learned Erasmus. Melancton said of him, "The least of his graces was that he was a painter." Dürer told Melancton towards the end of his days that nature had not unfolded herself to him when young, that he had only learned the charm of simplicity too late, and that he mourned over his early pictures.

Dürer was realistic in form, but he was ideal in thought. We have one portrait by him in our National Gallery-that of his father (1938); it was painted when Dürer was twenty-six years of age in I497. It is most animated in conception, light and spirited in execution. The old face is seamed with wrinkles; the curly hair, which is scarcely grizzled, falls from under a black cap. He looks forth seriously with patient anxiety on his brow. It is an excellent portrait, painted with love.

Dürer lived in Nuremburg, and in that city of dreams we still see the gabled house in which he toiled. I hope that you will see it yourselves and that you will think of the steadfast and earnest painter at his work. Of Dürer, his friend, the painter Birkheimer, said, that he "united every 
virtue in his soul, genius, uprightness, purity, energy and prudence, gentleness and piety."

Germany was miserably poor, and Dürer, to live, had to devote himself to wood-engraving. Venice offered him two hundred ducats a year if he would settle in her midst, but he would not leave his beloved country. His death occurred on the $5^{\text {th }}$ April $\mathrm{I}_{528}$. He left many treatises behind him, including one on "proportion."

Lucas Cranach, his contemporary (I472-I553), had much of Dürer's genius. $\mathrm{He}$ was a great friend of Luther, whose rugged face he painted often; and it is said that he brought about the marriage of the stern reformer with the nun Catherina Bora. "Portrait of a Young Lady" (29I) is a very good specimen of his portrait painting; the tone of colour is warm and luminous, and the head is altogether pleasantly conceived.

Now let us pass to the artist who is the glory of the school of Augsburg, Hans Holbein the younger (I497-I543), son of a painter of eminence. Surrounded from his childhood by artistic influences, Hans Holbein soon became the king of portrait painters; yet it was not only as a portrait painter that he excelled but in all branches of art. Let us remember the beautiful Madonna at Darmstadt. This gracious and lovely woman with her golden crown is a true Protestant Madonna. She has laid aside her halo and shines forth in her perfect womanhood. Holbein, above all things, represented men and women as they were, painting what was noblest in them, their souls and their intellect. He came 
over to England bearing a letter of introduction from Erasmus to Sir Thomas More, to whom he brought a portrait of the great theologian which was more like Erasmus than the one done by Albert Dürer. The friendship of the great Chancellor kept Holbein in England, and we may often think of him at More's house by the river, wandering in the beautiful garden. He painted the portrait of More's wife, of More's beloved daughter, Margaret Roper, and of the other children. We know that Holbein sent a drawing of More's family to Erasmus, for there is a letter still extant thanking him for the gift.

At Hampton Court there are twenty-seven portraits by Holbein, and they resume his whole life. At first we find him the cold, correct draughtsman, then by degrees his manner becomes softer, his colouring more transparent and brilliant. $\mathrm{He}$ painted the picture of "The Ambassadors" (I3I4) in I533. It was at first thought that Sir Thomas Wyatt, the most accomplished gentleman of the time in England, was the original of the figure wearing the order of St. Michael. But now we know that the portrait is of Jean de Dinteville, who was ambassador from France to England in I533, and that the other portrait is of George de Selve, his friend, Bishop of Lavaur. Holbein's insight into character, the force united with delicacy of his colouring, the certainty of his line carved as by a chisel have made this portrait-group one of the wonders of the art-world. You must study it yourselves and get to know the meaning of all its 
marvellous detail-the varied mathematical implements, the globe, the compasses, the wind instruments, everything expressing the calling and the tastes of the two men.

Henry VIII. had the greatest admiration for Holbein. "I can make a lord of any one," he used to say, "but I cannot make a Holbein." It was one of the painter's duties to take the portraits of the ladies the King proposed to wed. We know with what disastrous results he had painted Anne of Cleves, making, as Henry VIII. said, "A Venus of her who was nothing but a Dutch frau." The widowed Duchess of Milan, daughter of Christian II. of Denmark, and niece of the Emperor Charles V., was very much admired by the King, and he sent Holbein to paint her portrait. It is here lent by the Duke of Norfolk. Look at her as she stands in her black student's gown and cap, with her pretty hands, wearing a big cornelian ring, crossed in front of her. How piquant she looks! She is only sixteen years of age and she is a widow already. She gave a sitting of three hours only to Holbein, but refused to give more. We seem to see the big dimple in her cheek as she sends a message to Bluebeard. Some doubt that she ever did send it, but I feel certain that she did; as I look at her animated face, her bright eyes, I seem to hear her say, "Tell his Majesty of England that if I had. two heads I would willingly put one at his disposal; having one only I prefer to keep it for myself."

"The Duchess of Milan" is lent to the National Gallery, and so you had better go and look at the 
portrait and feel the centuries roll away as you gaze at the speaking countenance.

I cannot tell you more of Holbein. He died of the plague, aged fifty-four, an unparalleled genius. After his death Germany was so distraught with the horrors and miseries of the Thirty Years' War that she could no longer encourage art, and art died away. 


\section{CHAPTER XXVI}

FRENCH SCHOOL

"Art is the child of Nature; yes.

Her darling child in whom we trace

The features of the mother's face, Her aspect and her attitude.

All her majestic loveliness

Chastened and softened and subdued

Into a more attractive grace,

And with a human sense imbued."

WE now come to the French school. Art is so woven into French life, and it is so much part of the spirit of the nation that we cannot conceive of France without art. In the days of Charlemagne architecture already flourished, and in painting, modern art was born with the Clouets.

François Clouet (I5IO-I572) was the son, the grandson, the nephew of painters. He had a native skill and delicacy of handling that came to him by the grace of inheritance, and that gave him a singular mastery of detail. It was in portraits that the Clouets excelled ; and the two portraits in our Gallery (66o and II9o), one a man's portrait and the other. a boy's, are very good examples of François Clouet's art. They are masterpieces of observation and style. They might pass for the works of-some Flemish painter. The painstaking accuracy of their 
detail, the illusive quality of their expression are peculiarly Northern, and we must always remember that the Clouets were of Flemish descent. The heads are detached against a sea-green background, a tint much affected by the whole Clouet school.

Then let us pass to Nicolas Poussin (I594-I665), who has been called "the painter of intellect." His culture lifted him high above the ordinary intellectual level of the public. Born in Normandy of a noble family, he went to Paris when he was a lad of eighteen. A friend showed him a collection of prints from Italy, and from that moment his soul was fired with the longing to go to Rome. $\mathrm{He}$ steeped himself in the classics. " $\mathrm{He}$ understood the ancients so well," says Sir Joshua Reynolds, "that he acquired the habit of thinking their way." At last he set forth and he reached Lyons, where the poet Marino employed him and finally took him to Rome. Nicolas Poussin continued to live there till his death, with the exception of a few years; these he spent in Paris in the service of Louis XIII. The King appointed him his "Painter in Ordinary." After three years, disgusted with the intrigues and jealousies of the gay capital, he rejoined his wife, returning to the city of his dreams. There he continued to reside for the rest of his life. He died in I665.

Nicolas Poussin adored books; he loved to look at sculpture. His knowledge and his feeling for Greek mythology surpassed those of every other painter. In his landscapes there is a dignified reserve; indeed reserve in landscape painting is too 
much the note of his art. In "Cephalus and Aurora" (65) the Greek mythology inspires every incident of the picture. A little Cupid is holding up before Cephalus the portrait of his wife Procris, and the hunter is trying to disengage himself from the embrace of Aurora. Behind is the white-winged Pegasus, beside him a river god sleeps, Apollo's horses melt into the shapes of the clouds. This love of classic learning is at once the strength and the weakness of Nicolas Poussin's art. In his two Bacchanalian Dances ( 42 and 62 ), accounted among the best things he ever did, all the ancient comedy is revived. The pictures are full of riotous frolic, full of varied incident, and they reveal the ideal of the Greek philosopher, Epicurus, that pleasure is the aim of life.

Nicolas Poussin adopted his wife's brother, Gaspard Dughet (I6I3-I675), who took the name of Poussin and became his pupil. There is a sense of infinity in Gaspard Poussin's pictures. In "The Sacrifice of Isaac" (3I) we feel the solemnity of the scene. The father is trudging up the hill bearing a lighted torch, the son is carrying the wood for the sacrifice, all nature is sombre; it seems to understand and to watch the tragedy of the deed about to be enacted. In "The Calling of Abraham" (II59) we have a magnificent study of sky, and it is Gaspard Poussin's skies that I want you to note: They give distinction to his pictures, they suggest the Infinite. I think in all the pictures by him in the National Gallery you will find that the skies are the keynote to the nobility of his conception. 
Very different from the learned Nicolas Poussin was Claude Gelée, known as Claude Lorraine (I600I682). He was very ignorant; he scarcely knew how to read or how to sign his name, and yet what poems of light are his pictures! The son of poor parents, he was born at Champagne, in the department of the Vosges, in the year I6oo. His parents apprenticed him to a pastry cook, and the pastry cooks of Lorraine were very famous in those days. When he had learned his trade he went to seek employment at Rome, and there became the servant of a landscape painter. He was his factotum, prepared his meals, ground his colours, and got from him his first instruction in art. Before long he found himself his assistant, for his master had been commissioned to adorn the palace of the popes. We can imagine how the little pastry cook was happy at his work. Then he returned to Nancy in Lorraine and apprenticed himself to a decorative painter of some celebrity in order to learn figure painting.

Before two years were over Claude was back again in Italy, the land of light, the country of enchantment, that had laid its spell upon him. Sandrart, a German painter, tells us many details concerning him-how Claude would be out in the open air before daybreak, stay there till nightfall, learning to depict "with a scrupulous adherence to nature's model the changing faces of dawn, the rising and setting sun, as well as the hours of twilight." He spent many years in this mode of study; sometimes, Sandrart says, he met him at Tivoli painting the well-known 
waterfalls. His landscapes are of a golden world under a golden sky. It is not for us to enter into controversy with Mr. Ruskin, who places Turner so far above the Frenchman; but is there not place for both these supreme painters in the world of art? Claude was a dreamer. His calm skies glow with a glory seldom seen on sea or land; his great palaces form the entrance of visionary seaports filled with visionary ships; his waves, illumined by the fire of the sky, lead us away in imagination to a fairy world. He has painted landscapes lit by the noonday sun and by the pearly light of morning, and all he paints declares the beauty of light. His aerial perspective, which is perhaps his greatest charm, lends a vast horizon to the scenes.

If Claude was not always true to actual nature, he was always true to dream-nature. He is a great composer of landscape; his ideal pictures may not be representations of what is, but of what might be; they are the outcome of his memory and of his broodings. Goethe has said that "Claude used his knowledge of the material world to express the world in his own soul." We have many pictures by him in the National Gallery. There are the two pictures, "The Marriage of Isaac and Rebecca" (I2) and the "Queen of Sheba" (I4). These are hung between two Turners, the "Sun Rising in a Mist" (479) and "Dido Building Carthage" (498). It was the express wish of the English painter that these pictures should be hung together, to form his appeal beyond the tomb, challenging the world to choose between the truth as he saw it and as Claude 
depicted it. Claude's two pictures have been greatly injured by restoration; still I think that they are noble pictures, true to classical tradition.

Let us look at "A Seaport at Sunset" (5). It is a fine and characteristic work with its Italian architecture, its ships lying at anchor, and, in the middle distance, the declining sun nearly level with the horizon. "Landscape with Figures" (I9), representing the story of Narcissus and Echo, is full of charm. It is radiant with pearly light, and its foreground is occupied by a transparent, shadowy pool in which Narcissus is admiring his own image. Mr. Ruskin finds great fault with the drawing of the trees. "Seaport: the Embarkation of St. Ursula" (30) is a picture full of delightful freshness. It is the early hour of the day when Ursula, a Sicilian princess, is starting with her maidens on a journey to the shrines of the saints before her marriage to a prince of Britain. We think as we look at it of Claude's early rambles, when he studied nature at all hours of the day. I cannot speak to you more of this great artist. $\mathrm{He}$ died in Rome in I682, and he was buried at La Trinita dei Monti. He was much appreciated a few generations ago. His serenity, his wide distances, all imbued with the charm of light, exercised a witchery over tired spirits. 


\section{CHAPTER XXVII}

FRENCH ARTISTS OF THE EIGHTEENTH AND NINETEENTH CENTURIES

"What men or gods are these? What maidens loath?

What mad pursuit? What struggle to escape?

What pipes and timbrels? What wild ecstasy?"

AfTER Claude Lorraine came the group of painters that represented the eighteenth century. This strange century was a mingling of sentiment and wit; life was a perpetual comedy of love, but the hearts of men and women were as a rule untouched. It was all a charming drama. Everything was most aptly said and demeanour was invariably courtly. Society alone existed at the time. Antoine Watteau resumes the genius of that century. It is a great miss in the National Gallery to have no picture by this master, for he was the founder of the eighteenth-century art; he may be said to have been its poet. His landscape is idealised; it was always peopled by men and women, in silken attire, who were the embodiment of cultured artificiality. Watteau died at thirty-seven, and already he dominated all the art of that time; but his art, perfect as it was, had in it the seeds of decay. We will not speak of Fragonard, another great representative painter, because he too has no painting in the National Gallery. 
Boucher (I704-I770) has one picture; Lancret (I690-I743), Watteau's other pupil has four-“"The Four Ages of Man." The art of both Boucher and Lancret was clever, graceful, and degraded in aim. Boucher earned a large fortune, and was the favourite painter of the ignoble Madame de Pompadour. Lancret fashioned himself on the art of Watteau, and followed the advice of the master to "imitate nature." Pleasure is the object of life in Lancret's philosophy, and you will see it illustrated in his four pictures in the National Gallery (ror, ro2, I03, I04).

We must now look at Chardin's two pictures. This painter stands for sincerity in a period of artificiality. He was born in Paris on the 2nd November, in the last year of the seventeenth century (I699-I779). His father was an upholsterer, and he is the painter of the lower middleclass. He seeks his inspiration in the humble world from which he sprang, a world very far removed from that of the court and society. His pictures contrast with those of Watteau and his followers. $\mathrm{He}$ is the only wholesome painter of a time when life was insincere and its pleasures far removed from the innocence of nature. He never looked for inspiration away from his own rank. The life of the tradesman class, its modest ambition, its fatigues, the order of its interiors, the joys of family life, the duties of motherhood-these are his themes. He first began by painting still-life, and he painted it always, but at first it was his exclusive study. He did not give himself the trouble to compose his 
groups. He threw on the canvas the objects he found to his hand, but what splendours of colour, what marvels of light are his!

Sometimes it was a silver goblet surrounded by fruit, sometimes, as here in (1258), it is a black bottle and a tumbler half filled with wine, a knife placed on a bit of newspaper. "Oh! it is not colour alone that you mix," writes the critic Diderot to Chardin; "it is the very substance of the objects; it is light and air that you render." Then he began to paint children, after that the mothers and women of the people. "La Fontaine" (r664) is a dazzling little canvas, rich in broken tints. A woman is turning the tap of a fountain. She is a healthy woman; we see the blood coursing in her veins; the texture of her linen apron and of her woollen skirt is rendered with extraordinary precision. All the hundred details of the picture are Chardin's own properties. The fountain from which she is drawing water, the pots and pans, are all as he saw them in his own kitchen. His painting lets nature into the artificiality of the eighteenth century. He is a great painter of still-life, a great painter of the quiet, lower middle-class. He was received by the French Academy in 1728 as a painter of flowers and fruit.

Looking at Greuze's pictures (I725-I805), we can understand the enthusiasm they aroused in Diderot, that remarkable man, who wrote criticisms of art while he was attending to the interests of the French nation. Diderot was sick of the immoralities about him; he hated Boucher and Lancret; he was weary 
of mythology; and when Greuze came with his homely pathos and his lovely girls, there was no limit to the enthusiasm with which he hailed them. Now we can see Greuze's pictures with cooler judgment, and we see there is a certain consciousness in his unconsciousness, and that his pretty girls are not altogether the simple creatures he depicts. The "Head of a Girl" (206) and his other two pictures, "Girl with an Apple" (IO2O)a sad little head with wistful eyes-and "Head of a Girl Looking Up" (Iorg) are full of girlish charm. It was the time when Rousseau wrote, and Rousseau, as you will know later, was a reformer who fought against the vices around him. He preached the return to nature. He was one of the forces that brought on the Revolution, and he, too, saw in Greuze's pictures the glorification of simplicity.

Greuze died in great poverty; he had squandered his money. The time of the Revolution was over; another art than his was now the fashion. He was far from the time in which Diderot had written, "Courage, my good Greuze; introduce morality into painting."

We come to Madame Vigée Le Brun (I755-I842), whose portrait of herself in her twenty-seventh year (I653) is a wonderful work. The shadow cast by her hat over her face is an imitation of that in Rubens" "Chapeau de Paille." She was a great favourite of Marie Antoinette, whose portrait she painted many times. It is difficult to imagine the terrors of the Revolution eddying about this lovely woman. She left Paris in haste and travelled, 
going from one great town to another always painting. The eighteenth century had sounded its last stroke-the nineteenth had come. Madame Le Brun spent many years in St. Petersburg away from her country.

The darkness of the Revolution had passed away, and the Empire, with its pseudo-classic taste, was a reigning power not only over French society, but over French art. David is the painter of the Empire.

We will pass over that time and come to the more modern period. Diaz de la Pena (1809-1876) was born at Bordeaux, and, from his earliest years, he studied nature. He was always out in the woods looking at the trees, at their shadows cast on the ground, at the effect of the clouds, at the rocks in the great forest of Fontainebleau. $\mathrm{He}$ would follow Rousseau, the landscape painter, studying and painting the landscapes that ultimately won him fame. "Sunny Days in the Forest" $\left(205^{8}\right)$ is a glade near a shallow pool, where the trees are lit by the afternoon sun.

Here is a fine portrait group, by Fantin Latour, of Mr. and Mrs. Edwards (I952). The artist is better known in England as a flower painter. He was born in Grenoble on January 14,1836 , and he died two or three years ago. This picture brings down the French school to the present time. Have you ever seen, I wonder, Fantin Latour's exquisite pictures of roses and pansies, of gorgeous peonies and humble stocks? He was the greatest flower painter of our day-greater perhaps than any flower 
painter of any period. The illustrious artist Whistler, writing to Fantin Latour, says of one of the Frenchman's flower pieces, "The effect is bewildering, and it seems to me you have discovered something new in the boldness of your colouring." Fantin loved flowers. "I have a garden outside Paris," he said, "and a tiny house in it, and there I get up at four o'clock on a summer morning and paint the flowers as they wake." $\mathrm{He}$ painted flowers for England and portraits for France. This portrait group of his friends, Mr. and Mrs. Edwards, is an exception to the rule. Mr. Edwards had begun life as a lawyer; he retired from his profession when he was thirty-eight, and cultivated painting and etching. In this picture he is represented seated, his left hand on a portfolio, examining an engraving, which he holds in his right hand. How finely Fantin has seized the scrutinising expression of his sitter's face. How splendidly he has painted the grey hair and rendered the beard. Behind him is Mrs. Edwards, standing with folded arms, dressed in black. It is an interesting picture, a study of life itself.

I want you to look particularly at "The Marsh Arleux-du-Nord" (2r35) not so much because it is a fine example of the artist's work, as because it is the work of Corot-the dreamer-the poet Corot. He was a man to whom the birds sang as he painted; the wind stirred the leaves about him, and he transferred to the canvas all the emotions they called up. Corot (I796-I875) was the son of parents in somewhat humble circumstances. His 
father held a small post under government, his mother was a milliner. When he was sixteen years of age he was apprenticed to a draper. He served him for seven years, and at last the desire of his heart was gratified, for all the time that he served his master his soul was absorbed in the love of art. He left his employer, and wrung from his-father a grudging promise that he would not oppose his wish to become a painter.

It was at the Ville d'Avray, a delicious spot near Paris, that Corot mostly lived and mostly worked, but he made many excursions in Italy especially, also in the South of Erance. At the beginning of his career there was something conventional in his methods, but he soon after reached his ideal, and this ideal was to study nature herself. I wish I could quote to you some of his letters telling of his happy love of art, of his humble spirit, ever seeking to learn from nature herself. He was delightfully simple. The folk of the Ville d'Avray called him "Le père Corot." He would go about in a peasant's blouse and paint out of doors, setting his canvas, preparing his brushes, smiling to the birds as they twittered around him, keeping his appointments with the dawn and with the sunset. He always painted the effects of soft light, of the quiet dusk; he never cared for the garish light of noon-day or for the splendours of sunset. Look at his pictures; you will see how subdued they are in tone, how light is the foliage of the trees. "It must be light for the birds to fly through," Corot would say. When you look at a picture by Corot, a picture of broad, 
subdued masses of colour, you must think of the simple artist happy at his work, happy in his love of nature. When Corot lay on his death-bed, he had visions of exquisite landscape ; and, as he died, he moved his hands as if he were painting still.

"The Horse Fair," by Rosa Bonheur, which is now placed in the Tate Gallery, but which is not to remain permanently there, is a magnificent work, one full of energy. Rosa Bonheur differed very much in her conception of animal life from that held by our painter Landseer. He made his beasts the comrades of man, sympathising, understanding all his moods. Rosa Bonheur painted hers as a distinct creation. In this picture we seem to hear the tramp of the horses' hoofs, we seem to feel their wild delight at the touch of the free air, and to sympathise with their acquiescence in man's power over them. All her life she was devoted to the study of animals. As a girl she used to spend hours in the Paris slaughter-houses, drawing from the poor creatures in their agony, learning anatomy from their bodies. Her studio in Fontainebleau had a number of stables.

When I was quite a little girl in Paris, I remember going to see Rosa Bonheur with my father and mother and Mr. and Mrs. Browning. It all comes back to me so dimly. There was a big studio with the pictures on easels and among others was this "Horse Fair." I remember that, when we came, Rosa Bonheur was not there to receive us, and yet we had come by appointment. We all looked at the pictures, and I remember how my 


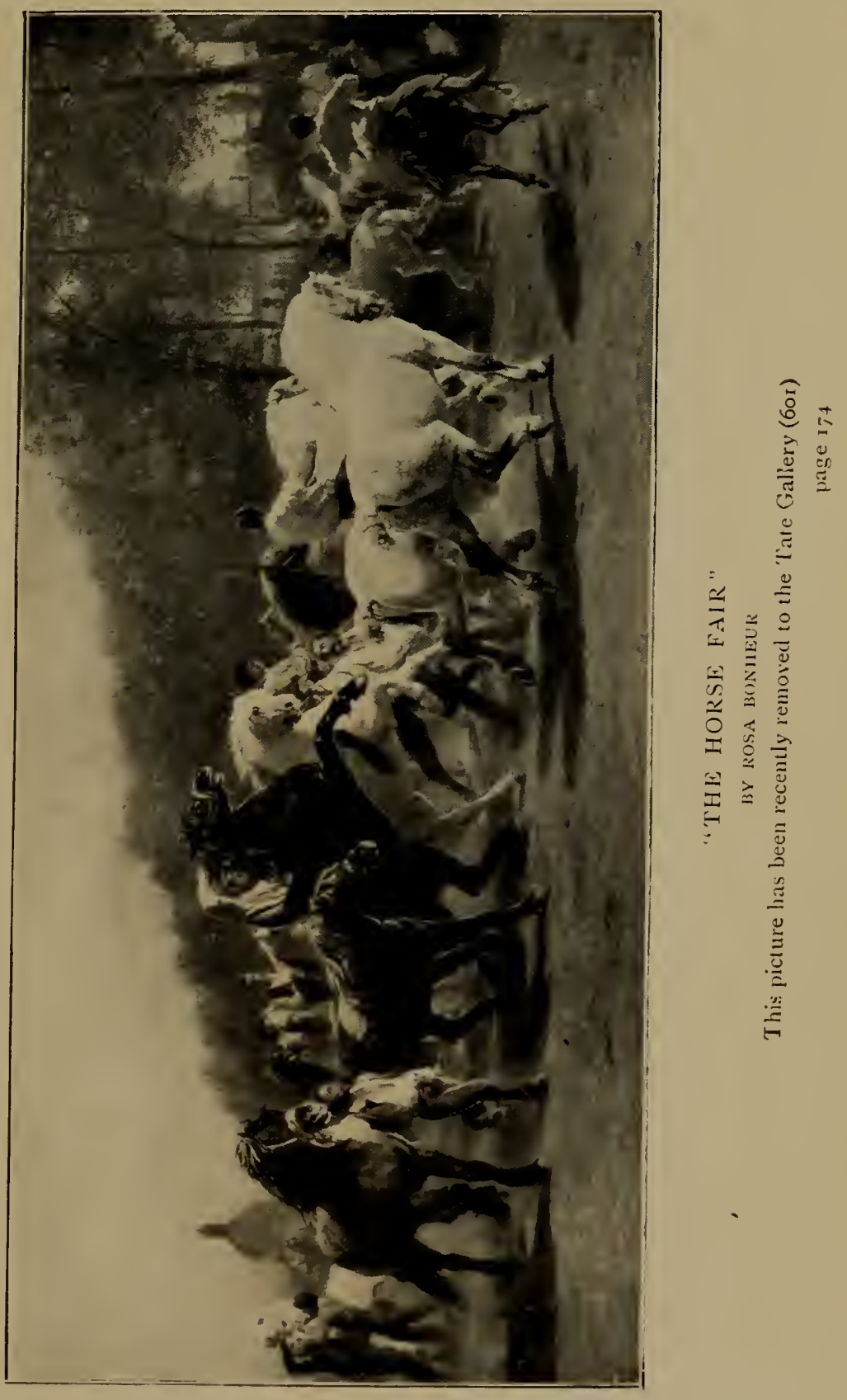



father drew the attention of his little daughter to the vigorous hoof of a strong white horse.

Still Rosa Bonheur did not come. Presently there was a noise, and I remember the start I gave when I saw creeping from under the table a laughing, brilliant woman in a costume that struck me as very masculine. It was Rosa Bonheur. She had fallen asleep under the table, resting after her lecture at the Jardin des Plantes, and she had overslept herself. I can never look at that wonderful picture without the memory of that day coming back to me. 


\section{CHAPTER XXVIII}

THE ENGLISH SCHOOL-THE THREE FOUNDERS

"O England! model to thy inward greatness,

Like little body with a mighty heart,

What mightst thou do, that honour would thee do,

Were all thy children kind and natural."

THE English school differs from every other school in the individualism of its members. Each painter of note stands by himself, isolated from his brother artists. It is therefore difficult to write of the art of England according to its school. Sir Peter Lely was not an Englishman; he came from Westphalia. Godfrey Kneller, who succeeded Sir Peter Lely in the royal favour, came from Lubeck. Neither could lay claim to being a member of the English school. England, for the first time, entered into the march of art towards the eighteenth century. The painters who came before that time were of foreign extraction, or greatly influenced by foreign schools. There were the admirable miniaturiststhe Olivers, the Hilliards, the greatest of all, Samuel Cooper, called the Van Dyck of miniature painting; but there are no miniatures in the National Gallery.

Three famous English masters are at the head of the English school; they were contemporariesHogarth, Sir Joshua Reynolds, and Gainsborough. 
Hogarth, with his merciless sarcasm, was a moralist painter-moralist first and painter after. Sir Joshua Reynolds was an accomplished student of the classics, a traveller in many countries, a man who knew the galleries of Spain and Italy, who understood the methods of the old masters, and who possessed besides an insight and a genius rare among painters. Gainsborough was a student of nature; he never went abroad; he learnt in the woods of Suffolk how to paint; he was a poet and a wizard of the brush. These three men are the leaders of the English school.

Hogarth was born in London, in the parish of St. Bartholomew, towards the end of I697. He died I764. His father had been a village schoolmaster in Westmoreland, who, fired by ambition, came to London to follow a literary career. He failed miserably and became a literary hack to a publisher. His son, William Hogarth, discouraged by his father's fate, resolved to learn a trade, and he learnt engraving. He made very little money by his engravings, and so he took to painting portraits and strange sarcastic pictures, founded upon his observation of the ridicules and the weaknesses of the time. He was resolved to win; he studied faces, expressions, attitudes. Everything that gave him a clue to the understanding of character he mastered. $\mathrm{He}$ was always sketching: wherever he went, his notebook went with him. His portrait, with that of his dog Trump by his side, will help you to understand him (II2). Trump and his master, I think, are very like each other. You will admit, 
as you look at them, that neither the one nor the other was likely to be beaten at anything he undertook to do. They have the same determined expression, the same challenging look. Hogarth said, "I have always found that nature herself is the best and safest course that we can follow in order to acquire the knowledge of our art." He was not a great colourist, but he was a marvellous observer. We seem to know all the originals of his portraits. Miss Fenton as Polly Peacham (II6I) ; a group of his servants (I374), each one curiously individualised; the "Shrimp Girl" (II62), a vigorous sketch of a jolly fishwife crying out her wares-all these and many others are likenesses that live.

Then we have his sardonic and terrible picturesa series (II3-II8) called the "Marriage à la Mode" - very painful to look at. Let us rather look at the "Calais Gate " or the "Roast Beef of Old England " (I464). It is a scene that an Englishman alone could have painted, I am quite sure. Trump must have very much approved of it. A man dressed according to the fashion of cooks in France, wearing a white cap and a large white apron, is carrying a big sirloin of beef. A fat monk, with an approving gesture, is feeling the joint. Behind him is a ragged, half-starved French soldier, also admiring the sirloin. There are Scotchmen and shabbily dressed Irishmen-mercenaries in the pay of France-looking with watering mouths towards the savoury dish. All Hogarth's pictures are chronicles of the time. We can see in them the bygone days, and they are often a sad spectacle to behold. 



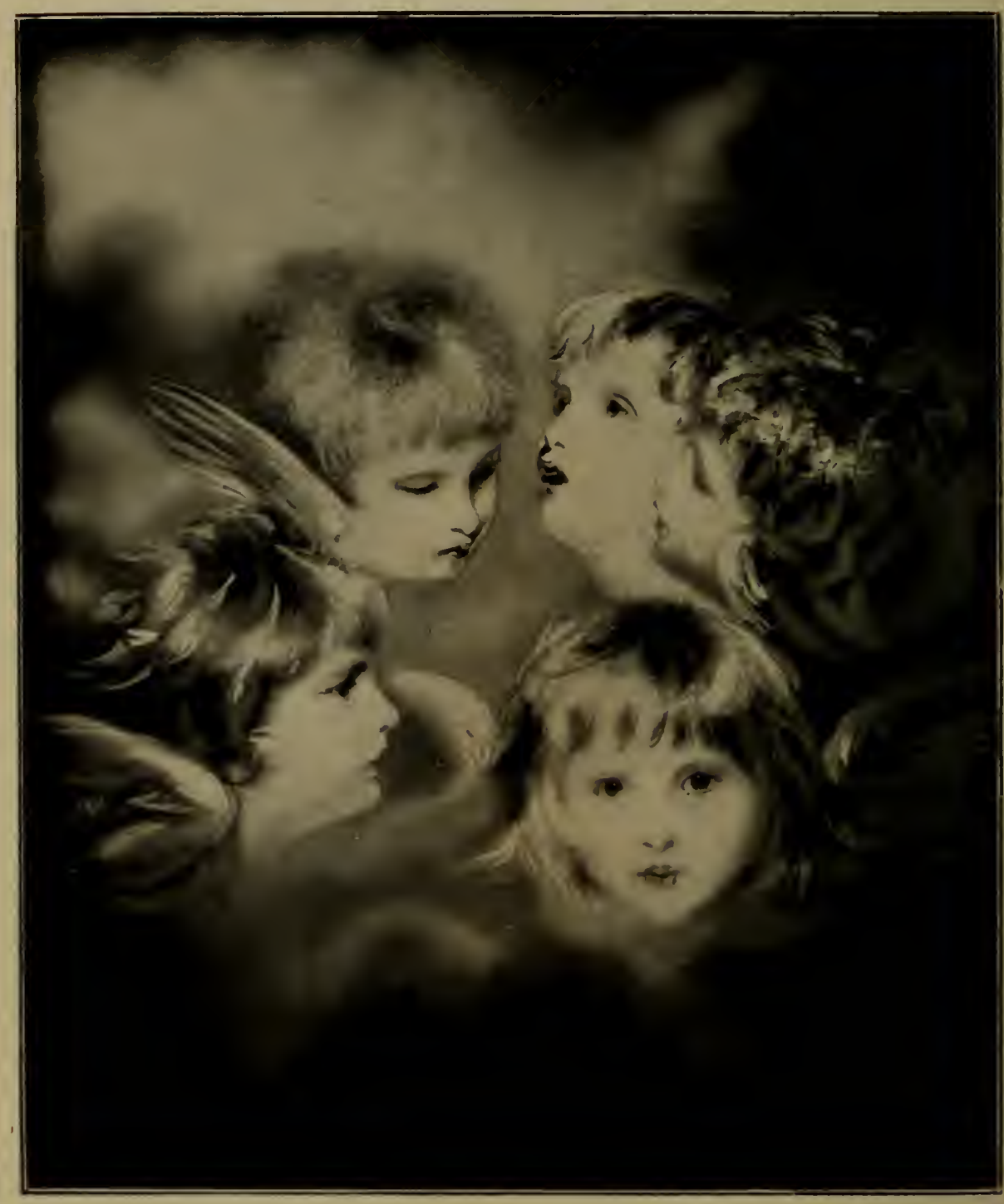

"HE.ADS OF AN(IELS" (ISG)

HV SIR JUSHUA KEYNOLDS, F.R.A. 
Sir Joshua Reynolds was born in 1723 and died in I792. Monsieur Chesneau, in his history of the English school, speaks of Sir Joshua Reynolds' works "as a magnificent victory of the will." His originality triumphed over all his studies. We know how impossible it is to mistake a picture by Reynolds in any collection. "I know no man," says Dr. Johnson, "who has passed through life with more observation than Sir Joshua." It was this quality that made him the king of portrait painters. He was an extraordinarily gentle and courteous man. "His grace has almost passed into a proverb," says Burke. It was but the expression of his charming mind, his delightful nature, his affectionate heart. "Heads of Angels" (I82) is a token of his sympathetic soul. It was painted for Lady William Gordon, who was broken-hearted at the death of her little daughter. Sir Joshua Reynolds could not speak of her grief; he felt for her, so he painted the child singing in the glory of heaven. If you look at the picture you will see the five faces are one face, bathed in God's transfigurating light. The picture brought consolation to the bereaved mother.

It is very difficult to decide which is the best of Sir Joshua Reynolds' portraits in the National Gallery-which is the most charming of these lovely ladies who smile down so serenely upon us, and who are so full of elegance, refinement, and grace. Is it the portraits of the daughters of Sir William Montgomery as "The Graces Decorating a Statue of Hymen" (79)-fair girls whose likenesses seem 
blown upon the canvas; or is it that of "Mrs. Hartley and Child" (I924), sometimes called "A Nymph with the Infant Bacchus" ? In her hair is a rose, round her waist a scarlet sash; she holds her child, who is crowned with ivy on her shoulder. Which is the most delightful of the children? Is it "Samuel" (I62), kneeling as he hears the mysterious voice calling to him, or is it the enchanting little girl sitting under a big tree called "The Age of Innocence" (307), or is it Robinetta (892) with her sweet and mischievous face? Which is the most heroic of the men? Is it Lord Heathfield (III), standing undaunted with superb obstinacy before the port of Gibraltar, holding the key of the fortress in his hand, the smoke of the artillery behind him ; or is it Dr. Johnson (887), in all his ugliness and all his greatness, all his wonderful sweetness and all the irritability of his nature speaking to us.

Gainsborough's art ( $1727-1788)$ is intrinsically different from that of Sir Joshua Reynolds, while it bears to it a superficial likeness. He is the poet of the brush, nurtured by the influences of the sun and the wind. Born at Sudbury, near Ipswich, he came to London when he was fourteen years old to learn the rudiments of art, but he was depressed by the teaching he got in schools and academies. Four years later he returned to his beloved woods of Suffolk. Fame found him out, but he still continued to study and to dream of nature. While Reynolds applied all the subleties of the varied methods he had mastered, Gainsborough loved the 
simple truth. In I774 he returned to London, and all society flocked to his studio. Great ladies wished to be painted by him, and Gainsborough represented all that was noblest and sweetest in them. In this lies the great difference between the art of Gainsborough and that of Sir Joshua Reynolds. Gainsborough's portraits are the result of his single attitude of mind before the truth. Reynolds is swayed and led by a thousand reminiscences and influences. Both results are beautiful, but both are the outcome of different principles. Gainsborough's masterpiece is "The Blue Boy," in the Duke of Westminster's gallery. It was painted as a protest against the dictum Sir Joshua laid down in one of his lectures, that blue cannot be made the dominant colour in a picture. Gainsborough took up his palette and painted that marvellous boy in his dazzling royal blue costume. All the portraits he has painted pass like a dream before me-a dream of fair women and brave men, with noble souls.

There is Mrs. Siddons (683) in her blue and white dress, her heavy black feathered hat, dignified, beautiful, and melancholy. There is "The Village Clerk" (760), the story of a simple and kindly life written in wrinkles upon the old face. The limpid eyes are turned towards the light. Every countenance that Gainsborough painted bears the stamp of truth. If we look at his landscapes we shall acknowledge that he deserves the title of "The Father of English landscape." All nature in her simplicity, her infinite variety, is in these landscapes. There is a lane near the 
river Orwell, close to Ipswich, in which I have often stood. It is called Gainsborough's lane. Tradition says that here he painted one of his most famous landscapes. I have felt there how nature loved her poet-painter and revealed to him all her delicate delights. Look at "The Market Cart" (80), the golden picture of a loaded waggon; the horse has just passed from the shaded pool on to the high road beyond. Look at "The Watering Place" (Iog). Do we not feel that it is a hot summer day, that the trees are enchanted by the sunlight, that the cattle are weary and glad to step into the cool water? Oh Gainsborough, wizard who make us feel what you felt under the spell of nature! Then there are Gainsborough's animals. How dear they are! Was ever an old horse painted with more loving understanding than this faithful and laborious animal (I484), tied by the halter to the ancient tree that is the symbol of his waning years.

"We are going to Heaven and Van Dyck will be of the company," whispered Gainsborough, as he lay dying, to Sir Joshua Reynolds. A misunderstanding had parted the two great artists, but they met again in the reconciling presence of death, and these were the last words that Gainsborough spoke. 


\section{CHAPTER XXIX \\ ENGLISH SCHOOL (Continued) \\ "I learnt to love that England \\ Such an up and down \\ Of verdure-nothing too much up or down \\ A ripple of land."}

WE must look at another landscape painter's works, those of Richard Wilson, who was born in I7I4, some years before Gainsborough, and who died in I782. He was an accomplished artist, yet his landscapes leave us cold near those of the Suffolk poet-painter. Wilson could not see things simply; he decked nature, he made her classic. $\mathrm{He}$ had been to Italy, the land of high art, and he loved that land and its associations so dearly that he could not paint our England simply as he saw it. There are many splendid pictures by Wilson-skies of pearly light, dark trees, the foliage of which form a frame to the classic scene beyond. L.et us look at "Niobe" (IIO). A cascade rushes down the rocks, and the landscape is a fit setting to the terrible tragedy enacted. Apollo and Diana are up in the clouds shooting down the children of the unhappy Niobe, because she mocked at their mother Latona for having two children only, whereas she had seven sons and seven fair daughters. 
Wilson was much neglected during his lifetime. England resented seeing her fair fields turned into classic groves. The King returned a picture of Kew Gardens that he had ordered. "It is not Kew," he said; it was some representation of a classic country, and he would not have it. Although Wilson was elected one of the first Academicians, he could not sell his works, and he became terribly poor. We are glad to know that towards the end of his life, by the death of his brother, he inherited a small competence, and was saved from the worst.

George Romney was another of the great painters of the eighteenth century. He was born in I734 and died in I802. The father was "honest John Romney," a cabinetmaker, who greatly, but vainly, wished George to follow his trade. George was bent upon learning to paint, and persuaded his father to place him with an artist named Steele. Later we find him with his friend the miniaturist, Ozias Humphrey, wandering about the Continent. He had married when he was about twenty-two, but he left his wife for many years. His whole heart was in his painting, and when he returned to London his works had preceded him and had already made him popular. He was the recognised rival of Sir Joshua Reynolds and Gainsborough. His favourite model was the exquisite woman, who later became Lady Hamilton.

She was a siren; she wiled away the hearts of men. Romney was always painting her-as Cassandra, as St. Cecilia, as a Bacchante, as a Magdalene; in every character the divine lady, as 
he called her, was more beautiful than in the last. Let us look at her as a Bacchante (3I2); her head is turned over her right shoulder, her exquisite mouth is smiling, her eyes look love. Then, again, in Cassandra (I668) what a world of woe lies in her prophetic eyes. It is always the same; as he painted her, she is the type of perfect beauty. Other women Romney painted, and to all he gave spiritual grace. Mrs. Mark Currie (I65I), with her cloudy hair, her hands half crossed, is a vision of happy and peaceful womanhood. His career was very successful, dividing the patronage of the aristocracy with Gainsborough and Reynolds. $\mathrm{He}$ went back to Kendal and died there, November I5, I802.

Then there is Raeburn, the Scotch portrait painter (I756-I823). Strong, straightforward, he looked his sitters straight in the eyes, and detected their souls as he painted them. He has a strong and simple manner that suited the painting of men rather than that of women, I should say than that of young women, for his old ladies in large mob caps are delightful to look at. The portrait of Lieutenant Colonel Bruce Macmerdoe (I435) is a fine breezy picture of a sailor, who is represented fishing; he has a clear, open, and intelligent face; (II46) is the delightful portrait of a lady dressed in white. I cannot dwell much longer upon the great portrait painters of the English school. It has excelled from the first in men gifted with the art of painting the human face.

There is Opie (I76I-I807), a man of great culture, 
wise in speech, and philosophic in his turn of mind. Two portraits, one of Mary Wollstonecraft (II67) and one of William Godwin (I208) are here. These portraits of remarkable personages are well worth looking at. Godwin is the author of "Caleb Williams" and two other weird romances. He was an advocate of freedom of thought in all things, and Mary Wollstonecraft, his wife, wrote a famous treatise upon the rights of women, and was the mother of Shelley's second wife. Opie was not a great painter by any means, but he was a remarkable man. He married twice. Mrs. Opie, the famous novelist, was his second wife, and she was devoted to him.

Then there is Hoppner, a charming painter, who was born in London in I759, and died in I8ro. He early entered the Royal Academy Schools. Gifted for song, he gave up his musical ambition for that of painting. In I782 he won the gold medal at the Academy. His mother was a German lady in waiting to the Queen. Hoppner was patronised by the Prince of Wales, who became King George IV. ; and soon attracted the attention of the fashionable world. Two camps divided the courts-one composed of Whig ladies who followed Hoppner, and the other of Tory ladies who followed Lawrence. But the two painters remained friendly rivals to the end, both taking opposite views of art, as they did of politics. Hoppner, although the follower of a prince of loose morals, cared for a demure and refined ideal of beauty. There is something almost Quaker-like in the purity of his conceptions, while 
Lawrence's ladies are graceful, and suggest somewhat easy morals. The Countess of Oxford (900) is a good specimen of Hoppner's delightful style.

Sir Thomas Lawrence was called the second Reynolds, and he was an infant prodigy. He recited, he drew, his manners were charming. He was well known long before he came up to London. Born in r769, he was of a good family who had fallen upon evil fortunes. He yet came early in touch with people, for his father had a large inn at Devizes. Later on he became the idol of fashionable society; everybody admired him, and was delighted to be with him. Byron speaks of his cultured and lively talk, and his sitters were charmed with his compliments. $\mathrm{He}$ was fond of his family, and he was always kind and generous to its members. Perhaps the greatest talent he possessed was that he knew how to paint the furbelows of fashion with grace and distinction, and to depict character in dress. He gave a curious look of animation to his portraits. His sitters seem as if they could speak to us, and yet we ask ourselves did he guess their souls. His portrait of Mrs. Siddons (785) contrasts with Gainsborough's dignified and melancholy representation of the same woman. It is a brilliant head, full of a seductive charm, but is it not too simply pretty for that of the woman Sir Joshua immortalised as "The Tragic Muse"? I prefer Lawrence's portraits of men. That of Benjamin West, P.R.A. (r44), shows us the venerable painter at the age of seventy-three. On the easel behind him is the 
sketch of Raphael's cartoon of "The Death of Ananias." Angerstein, the collector whose pictures formed the nucleus of the National Gallery (r29), and Romilly (1238), the great lawyer who reformed the cruel laws, are here, and in them you will see Lawrence at his best. They are simply and nobly expressive ; they show none of the freaks of passing fashion so noticeable in his portraits of women. Lawrence was President of the Royal Academy. He died in I830, and was buried with pomp in St. Paul's Cathedral. 


\section{CHAPTER XXX}

THE NORWICH SCHOOL AND OTHER PAINTERS

"All in the April morning,

April airs were abroad.

The sheep with their little lambs

Pass'd me by on the road."

THERE was formed in Norwich an association of painters that called itself the Norwich school of artists. Its leader and founder was a simple man of simple life, who has ever since been known as "Old Crome" (I768-I82I). This designation of "old" is really to distinguish him from his son, who succeeded him in the leadership of the school. He was born at Norwich on December 8, I768. His father kept a public-house, and he was brought up to be a coach painter, but he rebelled against his fate and he was apprenticed to a sign painter. $\mathrm{He}$ married very young. It was in I805 that he gathered together the artists and formed the Norwich school. Its members had a common painting room; they held exhibitions, and their works became famous, that is the works of their leader John Crome, with whom was associated Cotman. But to us the Norwich school is Crome.

Hobbema was his spiritual ancestor, and the art of the Low Countries inspired him. To him the $\$ 89$ 
trees, the airy spaces, the sky with golden floating clouds, the solitude and stillness of out of the way places were all delight. Their spirit dwells in the aspects of nature that he was always striving for. $\mathrm{He}$ is the very reverse of Wilson, who always, as you know, sought some classic theme. Crome loved simple things. "Mousehold Heath" (689) is a representation of solitude and stillness - a grassy slope, a foreground of heath and thistles, golden clouds above. He knew a particular tree as you know the face of a friend, and he especially loved the oak. He had a perfect passion for fidelity; he loved shadow and sunshine, the shadow of deep places, the sunshine of the afternoon light. "Landscape-Slate Quarries" (I037), a picture of desolate Welsh slate quarries where men are labouring. "The Windmill" (926), a very suggestive picture of a mill set on a hill, and of a man trudging home from work.

This unaffected and genial man, honest and homely, cared only for the scenery of his own county; he lived and died at Norwich. We can imagine him every night going to the public-house as to an informal club, no more understanding what we call "impressionism" than he would have understood some new fangled word. He painted what he saw, and the things that appealed to him most were air and space.

He died in I82I, and if we read the local records of that time we shall see that there was a fine funeral given to him, that all the notable inhabitants of Norwich turned out to do honour to the man 
who had painted their county so faithfully. $\mathrm{He}$ left his son behind. He also did good work, but it is always of old Crome that we think when we mention the name. I like to remember him as he was, in his simple life, painting at his easel, or talking with his comrades of local affairs.

Cotman (I782-I842), was a foremost member of the Norwich school. He spent long years at Yarmouth, where he studied all things nautical. "River Scene" (IIII) - wherries on the Yare-is a good example of his love and faithful observation of the sea.

If we turn from Norwich we find George Morland, prince of the painters of farmyards, who lived principally in London pot-houses. He was born in I763. His life is a sad example of the power of dissipation over a great mind; it is a record of arrests, of fleeing from creditors, of going to jail for debt. We hear that he was arrested in I799, and sent to prison and finally released in 1802 , and that he died suddenly in 1806 while under arrest for debt. When his wife, who was the sister of William Ward, heard of his death, she succumbed to the shock, and both were buried on a November day.

Nothing can be sadder than George Morland's life and death; he was a man of genius, the painter of England's rural life in its homeliest aspect. It was the common things that interested him, and there was no misery for him in doing common tasks. If you look at "The Inside of a Stable" (I030), see how beautifully the two horses and a pony are painted, how exquisite and how tender is 
the light and shade, how charming is the whole atmosphere of the picture. Unfortunate George Morland, gifted and debased in taste, who loved the humble animals, and led a life that would have shamed them! We can but think of him with sorrow as we look at this beautiful picture, glorified with the light of real genius.

Stothard (I755-I834) is the very opposite of George Morland. He was orderly, a modest, contented man, and thus he remained to the end of his life. The son of a well-to-do innkeeper in Long Acre, delicate in health, his gentle spirit never rebelled against the existing order of things. He was always drawing in childhood, so his father apprenticed him to a draughtsman of patterns for brocaded silks, and the boy took very happily to his work. His father died and his mother placed him under an artist, and all her son's feeling for grace came out in his drawings. There was a sweet, grave humour about him that found expression in his art. He began to devote himself to illustration, and this turned out to be the work of his life; in it he is without a rival. Perhaps the finest thing he ever did was the "Pilgrimage to Canterbury" (II63). It is a long, horizontal composition, in which are numerous figures, all mounted on horseback riding in cavalcade. It is quite delightful to trace the different pilgrims - " "The Knight and his Son," "the Yonge Squier," "the Vife of Bath," talking with such winsome coquetry to the Pardoner, "The Clerk of Oxenford," the Nun talking to her superior, the lady Prioress, "Madame 
Eglentyne," and all the goodly company that is described in the prologue to Chaucer's "Canterbury Tales." The freshness of the May morning is conveyed in this enchanting frieze. "A Greek Vintage" (3I 7$)$ is a graceful illustration, full of innocent gaiety.

Stothard had a great feeling for grace of costume. I must not dwell longer upon him. I have seen his portrait painted in his old age, and it is the face of a man of dignity and delicate observation, one possessed of more sweetness of temperament than of vigour. He died in I834. He was neither rich nor poor, but much esteemed and much honoured by all who knew him. 


\section{CHAPTER XXXI}

\section{ENGLISH SCHOOL : CONSTABLE}

\section{"And whoever wakes in England}

Sees, some norning, unaware,

That the lowest boughs and the brushwood sheaf

Round the elm tree bole are in tiny leaf,

While the chaffinch sings on the orchard-bough

In England-now."

AND now we come to the two greatest landscape painters of the modern English school, Constable (I776-I837) and Turner. At first endless difficulties beset Constable. He loved the springtime, the time of blossoms, of sunny showers and sudden bursts of sunshine. The rain-twinkling leaves, the rain-soddened grass, the wind singing, the great clouds rolling before it-these are what Constable paints. But the artists of his time did not believe in the glorious awakening of the season as a theme fit for painters. The freshness of spring had no place in art, and it was in vain for Constable to persevere painting picture after picture. They remained unsold, proclaiming his enthusiastic delight in the caprice of nature, in the passionate breath of the North wind, in the early greenness of the day. He walked out in the dewy mornings, "And at every step I take," he wrote in one of his letters, "I am reminded of the words of Christ, "I am the Resurrection and the Life." " 
Still his pictures remained uncared for. $\mathrm{He}$ had nearly reached his fiftieth year when, in I824, he exhibited in Paris, and, for the first time, tasted appreciation. The new school of landscape painting chose him for its leader, chose him because he was totally opposed to classicism, because he cared only to express what he felt.

The French recognised in Constable the leader of a revolution in the art of landscape painting. $\mathrm{He}$ was the herald of what we now call impressionism. It is his delight that we feel in every stroke of his brush. Life, movement, emotion appealed to him. He was the very reverse of Wilson, of Poussin, even of Claude Lorraine. He imitated no master before him. His thought alone swayed him. Look at "The Cornfield" (I30). The great cornfield in the middle distance bathed in light, the elm trees on either side of the road dividing the fields, the distant steeple of the church, the wonderful sky full of great masses of pearly clouds ; it is a summer day such as Constable felt it. We cannot remain cold before it, for in our soul rise memories of similar days. This is the difference between the classic picture and one of impression. The artist, in the latter, gives himself. We feel with him the scene he presents. In the classic picture there is something always remote in its serenity, something that belongs to. tradition, and in a tradition apart from our daily life.

He was born at East Bergholt, in Sussex, in 1776 , and, as Gainsborough did, he spent his youth in his native county. He was the son of a miller, and 
his father wished him to take up his own profession. But the lad longed to be a painter. He came to London and entered the Royal Academy in I8ro, and he was greatly encouraged by Sir George Beaumont. He married in $18 \mathrm{I} 6$, and he came to live in Hampstead in 1820 . This beautiful neighbourhood was at once the inspiration and the study of his art.

"The Valley Farm" (327) is a delightful picture of a red-roofed farmhouse, a farm in which its owner, Willie Lott, spent his life of eighty years, being absent during that time but four days and nights. Here is one of Constable's wind-swept skies; the water is full of shadows of broken reflections; it fills the foreground and stretches away, while great trees form a cluster on the bank. (I8I4) is a sketch of Salisbury Cathedral, one of Constable's most famous pictures. A rainbow spans the sky, showing the church shining there like a vision; the river flows past osier beds, and is forded by a waggon and a team of three horses.

I must not dwell longer on Constable. His works hold me by the charm of his impetuous and religious spirit. You will often find his pictures in private galleries here and also in Paris; they are always different, and yet they always resemble each other. The masterful representation of nature, the dewiness of the grass, the joyous clash of wet leaves, the glint of the summer sunlight are in all of them.

He died at Hampstead, where he had lived so many years, April 1837 . 


\section{CHAPTER XXXII}

\section{ENGLISH SCHOOL : TURNER}

"Leave him still loftier than the world suspec:s

Living and dying."

TURNER was the son of a barber, and he was born in Maiden Lane, Covent Garden, in I775; he died in I85I. "The Sun is God" were Turner's last words, and they gave the keynote of his life-work. It was devoted to the painting of light, the problem that had baffled so many held him by its marvellous intricacies, its reflections and gradations. If we look at the glorious pictures in the two rooms called the Turner Gallery, you will see that all have the same aim-all strive to render the subtleties and the splendours of light.

I will not worry you about the first and second period of Turner's art, for both served this one dominant object. Others had tried to paint light. De Hoogh had striven for it, and filled with it his Dutch interiors; Claude Lorraine had made the sun rise and set in a glow of gold; Rembrandt had been . the great magician, using shadow to bring out its glory. Turner came, and, setting aside shadow, made light the supreme ruler in landscape. If you will examine these $\underset{\mathrm{r} 97}{\text { pictures carefully, you will }}$ 
see that Turner little by little laid aside the old conventional treatment of bringing out light by the contrast of deepening shadows, that little by little delicate grey replaced the dark bituminous spaces, and light reigned supreme.

1 I think that in "The Bay of Baiæ with Apollo and the Sibyl" (505) his triumph was assured. The lovely sunshine of Italy is over the scene of ruin: no shadows compete with its charm. Still it is a desolate picture. The sub-title, "Apollo and the Sibyl," makes us understand its desolation, for Apollo had loved the Sibyl in her youth, and had granted her prayer to live as many years as there were grains of sand in the handful of earth she held. But he had not given her perpetual youth, and we see her in this picture a haggard figure, the type, says Ruskin, "of the ruined beauty of Italy."

Another picture characteristic of the splendour of sky, the magnificence of line, the pathos of past achievements, is "The Fighting Téméraire tugged to her Last Berth" (524). It is a very affecting picture. After her long day's fight is done, the vessel is gliding home to her rest. The sky is illuminated with the variegated rays of the setting sun, the sea is a road of light over which the magnificent veteran ship is being tugged. All the feeling of England is in that picture-infinite love and gratitude for Nelson, tenderness for the noble vessels that helped him in his struggle with the enemy. All heaven is a blaze of gold and scarlet, all the sea is a pathway of glory for the grand old vessel to traverse. 


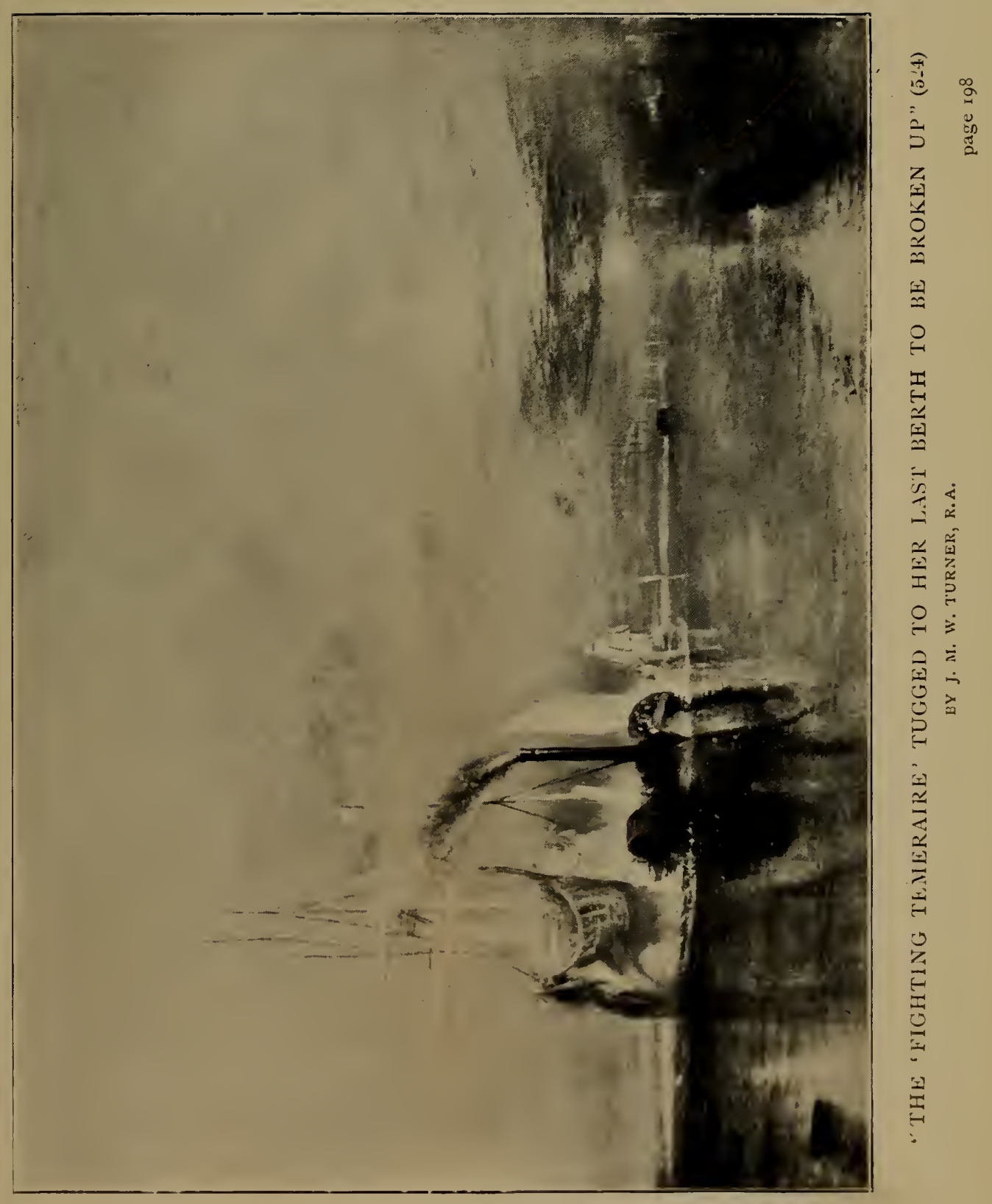



"Captain! my captain! our fearful trip is done.

The ship has weather'd every rack, the prize we sought is won. The port is near, the bells I hear, the people all exulting, While follow eyes the steady keel, the vessel grim and daring."

"Ulysses Deriding Polyphemus" (508) is another picture we must look at. Every intricacy of crimson light fires the restless waves. From a luminous centre emerges a tangle of flaming clouds, reflected in the sea below. It is sunrise, and Ulysses is putting off from the island. We see the monster sprawling on the top of a cliff, while close to shore are the remains of the fire in which the olive staff was burnt, with which Ulysses and his followers put out Polyphemus's one eye.

We can but notice some of the noble pictures in this Gallery, and in Room XIX. Here are the three pictures $(370,534,535)$ of Venice, a pearly white city rising out of the sea, dream-like, dimly radiant, a ghostly town seen in a golden light. There is "The Garden of the Hesperides" (477), a picture full of meaning. The three fair daughters of Hesperus are singing about the golden tree, and the Goddess of Discord has come to choose the apple which Paris is to present to the most beautiful of the goddesses. From that choice is to arise the war of Troy. It is a characteristic picture.

"The Death of Nelson" (480) represents the hero towards whom all England's eyes were straining, having just received his death-wound. It is a magnificent picture, worthy of its great theme.

You must look at the superb, but much impaired, "Childe Harold's Pilgrimage" (5I6), a picture 
that represents all the outdoor life, the feasting and dancing of Italy, bathed in the luminous atmosphere peculiar to that country. "Crossing the Brook" (497) Ruskin describes as glorious in composition, and perfect in all that is most desirable and most ennobling in art." Then let us look at "Peace: The Burial at Sea of the Body of Sir David Wilkie" (528), a tribute paid by the great English painter to the great Scotch painter, "Train, Steam, and Speed" (538), a wonderful attempt to represent the dash and wonder of a train going at full speed. These are but a few, a very few of the pictures in this Gallery.

Turner belongs to no school; he expresses himself and himself alone. He was in love with the sun, possessed by that love of light which it became his aim to express in art. You must study his pictures again and again; you must return to them until the passion of his soul becomes the passion of your own. 


\section{CHAPTER XXXIII}

LESSER LIGHTS YET GREAT

"A man's a man for a' that."

Sir David WiLkIE (I785-I84I) was the son of a Scotch minister. He was born in November $I 785$. The child was father to the man, for nothing pleased the laddie so much as scribbling in pencil on his copybook and on every piece of paper he could lay hands on. He never sought to illustrate mythological subjects or fairy stories. It was always the animals, the surrounding objects, the people about him, which the little mannikin was drawing. At last he was allowed to cultivate his gift, and, in I799, when he was just fourteen, he was placed in the Trustees Academy at Edinburgh, and, in I805, he became a student of the Royal Academy schools. Oh these happy student days, how Wilkie loved them! How hard he worked, how frugal he was; all this is related in his biography. He had many friends, amongst whom was Haydon, the self-centred, the warm-hearted, the unfortunate painter. It was in rendering the actual life around him that Wilkie from the first excelled, and it was this talent that had been foreshadowed in his childish scribblings. "I could draw before I could read, and paint before I could spell," he says. 
$\mathrm{He}$ has been compared to Goldsmith, the Goldsmith of art; the comedy and tragedy of life as it went on around him, its humour, its delicious contradictions, its simple yet often heart-breaking pathos, charmed and attracted him. Everything that was sincere, however humble, interested him. If we compare him with Hogarth, we will see that as Hogarth saw nothing but the baseness of life, Wilkie saw its pity and its innocent happiness, $\mathrm{He}$ inspired great affection, and he gave it back with all the strength of his nature. Haydon has told us that the "Village Politicians" was exhibited in I806, and was very favourably noticed in the papers. When he read the notices, "I was in the clouds," says Haydon, "hurried over my breakfast, rushed away, met Jackson, who joined me, and we both bolted into Wilkie's room. I roared out 'Wilkie, my boy, your name's in the paper.' 'Is it rea-al-ly?' said David. I read the puff. We huzzaed, and, shaking hands, all three danced round the table until we were tired." Next day the friends went arm in arm to the Gallery. There was no getting near. Wilkie, pale as death, kept saying, "Dear, dear, it's just wonderful." From that time forward his success was assured.

Here is "The Blind Fiddler" (99). Wilkie was a great admirer of the Dutch school, and, in painting this picture, he borrowed one by Teniers, and kept it by him all the time he was at work. It shows the interior of a farmhouse; the mother tosses her baby to the tune of the fiddler, the father snaps his fingers, the boy, making a pair of bellows his fiddle, 
the poker his bow, mimics the musician, the girl listens intently; even the dog is all attention to the music. The picture is full of elaborate details and none are far-fetched. It is a scene that might take place in any happy home circle. Another picture, "The Village Festival" (I22), and "The Bagpiper" (329) are pages torn from the life of the rustics about.

Wilkie had a second manner in which he became an historical painter. His most celebrated historical picture was "John Knox Preaching to the Lords of the Congregation." Wilkie grew more and more in popularity. He was made an Associate in I809, and a full R.A. in I8II. After the death of Sir Thomas Lawrence, he was appointed painter in ordinary to his Majesty, and, after the death of Sir Henry Raeburn, limner to the King in Scotland. Then came a short period of illness and his sudden death. He had gone in search of health to the Holy Land and to Egypt. He died on the Ist June, I84I. His body was committed to the deep, and Turner painted the scene. "I wish I could paint them blacker," he said, when some one objected to the black sails in the picture.

Let us now look at two strange pictures by Blake, the poet-painter (I757-I827). He was a visionary, and he painted visions; he was a poet with the heart of a child and a child's imagination. He wrote the "Songs of Innocence," those lovely songs pure and bright as the voice of spring. He ornamented each song with a fanciful border, printed poem and design in wonderful colours. It 
was his dead brother, he said, who appeared in a dream and taught him thus to ornament his poems. Wordsworth and Shelley were singing of the war of the spiritual and the material world, and Blake, enraptured by Wordsworth's poetry, dreamt of bringing mystic Swedenborgianism into art. $\mathrm{He}$ lived among dreams and spirits, and people called him mad. They did not buy his pictures, they paid no attention to his poetry, but he was content. In the picture of "The Spiritual Form of Pitt guiding Behemoth" (IIIO), we see the spiritual form of Pitt as Blake imagined it. "Pitt," he says, in his catalogue to the pictures he exhibited, "is that angel who pleads to perform the Almighty's order." The picture really means the power of statesmanship to control the brute forces. It is full of a strange symbolism. I could write to you much about Blake's beautiful soul. He lived and died in great poverty, always sustained by the love of his wife, and for all the misery of his outward circumstances he was happy. "May God make this world to you, my child, as beautiful as it has been to me." he said, stroking the hair of a little girl who had been brought by her mother to see him. As he lay dying he sang songs to his Maker. His life is a beautiful and unique example of the spirit triumphing over all the diverse circumstances of the material world. His other picture in this Gallery is the "Procession from Calvary" (II64).

Landseer (1802-I873) contrasts with this mystic painter. $\mathrm{He}$ is the painter of dogs and of all the dear dumb creatures that we love. He knew all their 
attitudes, and their least movements possessed a meaning for him. He sympathised with them so much that he made their expression quite human. For this he has been found fault with, and yet it is this which draws us to him. The texture of the animals' coats, the fire or the wistfulness of their eyes, the eager poise of their bodies in action, the beautiful laxity of their lines in repose, all this he studied. He has gained his knowledge by his loving watchfulness. He entered the Academy schools when he was thirteen. "Where is my little dog boy?" Fuseli, the keeper, used to ask when Landseer was missing.

I think the animals understood and loved him as much as he loved and understood them. A story was told me by a friend of his that I have never seen in print. Landseer had a beautiful dog, which he was always painting. The poor dog did not like to be made such constant use of, and he plainly showed his reluctance, and told his master that he thought it unfair. One day Landseer said to him, "This is the last time I shall ask you to sit, the very last," so the dog wagged his tail and sat beautifully and patiently to the end. When the picture was done Landseer renewed his promise, and the dog henceforth took his ease and was happy. One day my friend came on a visit to the artist. "This is a jolly dog of yours ; I should like to paint him,". he said. "Certainly," replied Landseer, forgetting all about his promise, and he whistled to the dog, and bade him sit. The dog, said my friend, sat up surprised; he looked at his master, and, when the 
signal was renewed, he threw his head back and uttered one long dismal howl, sprung out of the window and disappeared. They sought for him everywhere, but Landseer had broken his promise, and the dog had vanished. I hope he came back after the visitor had left.

Landseer was very young when he began painting. His father was an engraver, and he educated his sons in art. At thirteen years of age the boy won a medal from the Society of Arts for the drawing of a large Alpine mastiff. From that time to the year of his death, in 1873 , his life was a series of triumphs. He was elected an Associate of the Academy when he was twenty-four, and four years later he was made a full Academician. He won the friendship of many remarkable men, among others of Sydney Smith and Dickens. He was as great a social, as he was an artistic, success; he sang beautifully; he told stories with great zest and point. The Queen and Prince Albert honoured him with their friendship, and the Queen knighted him in 1850 .

"Dignity and Impudence" (604), is a perfect bit of character drawing. Grafton is the name of the bloodhound who stands alert, with chest thrown back and head uplifted, intently watching. His paw hangs over the lintel of his kennel, but he is not fussed; he is quietly surveying the stranger who is entering, and whom we do not see. He is "Dignity." A small Scotch terrier represents "Impudence." $\mathrm{He}$ sits in the same kennel, and he is all in a flurry at the approach of the stranger; we seem to hear him bark. It is a perfect repre- 


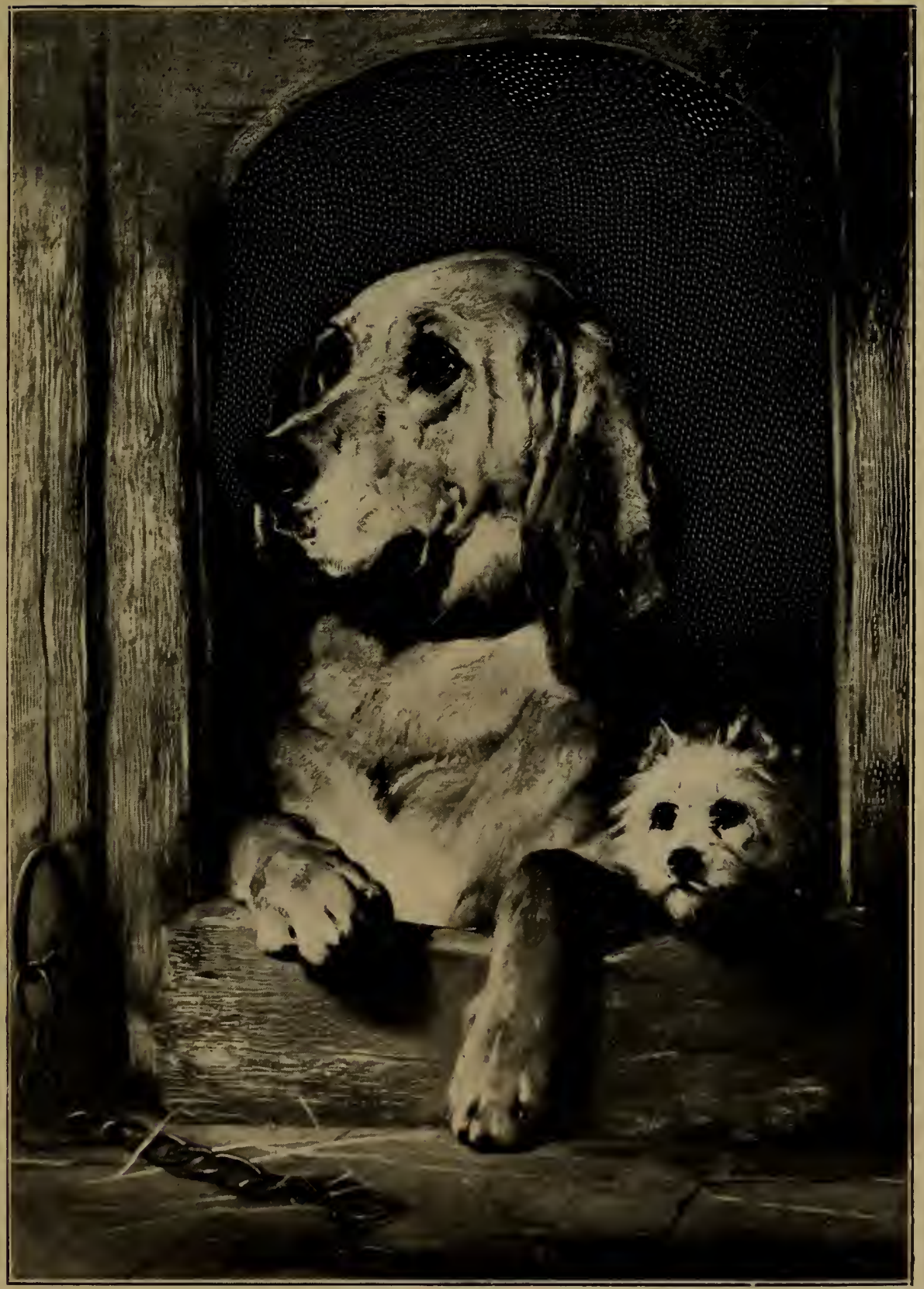

"DIGNITY AND IMIUUDENCE" (60.)

BY SIR EUIIN LANUSEER, R.A, 

sentation of dignity' and impudence. See how beautifully the glossy hair of the animals' coats is painted, their eyes speak. Then look at "Shoeing the Bay Mare" (606). A farrier is trying on a shoe on the hind foot of a mare, whose name was "Old Betty," and she stands in a characteristic attitude ; on her neck is no halter, for "Old Betty" would never wear one. She used to love to go to the blacksmith to have her shoe put on. The bloodhound who is watching is called Lama, and the donkey in the background, a grey furry donkey, is also watching. The farrier is a portrait. I want you to notice the glossiness and crispness of the hide of the animals. It is really a portrait group. We seem to know the three animals"Betty," the mare of character, "Lama," the bloodhound of observation, and the dear old ass behind -all are watching intently the farrier at his work.

"The King Charles Spaniels" (409) and "The Sleeping Bloodhound" (603) are the beautiful representations of three animals who all died violent deaths. The bloodhound had fallen asleep upon a balcony, awaiting his master's return. He heard the wheels of his carriage in the distance, and, leaping down, missed his balance, fell between twenty and thirty feet, and died during the night. Landseer painted the splendid dog while he lay dead. The little spaniels also died from falls.

Landseer, the lover of animals, died in 1873 , and received a public funeral in St. Paul's Cathedral. The design is his of the great lions at the foot of Nelson's statue in Trafalgar Square. 


\section{CHAPTER XXXIV}

\section{CONCLUSION \\ "All's well that ends well-through art's magic."}

THE work of artists of the English school, and there are many, are in the Tate Gallery, the adjunct of the National Gallery. You must go there to study them - Mulready, Leslie, Etty, Ward are there. I think that you will agree with me that the peculiarity of the English school is its singularity. It differs from every other school. It is essentially itself. The English people are thought cold and insular by the continental nations, and their art expresses their separateness.

You have heard of the pre-Raphaelite movements, the object of which was to revive the faithful study of nature - its ideal was sincerity. The pre-Raphaelite Brotherhood, as the artists who formed it called themselves, painted with fine, small touches; they omitted what are called the values in painting. The effect was often that of hardness.

Millais (I829-I896), our great artist, joined the brotherhood, but, after a while, he returned to the old school with its broader methods. Still the discipline of his pre-Raphaelite studies clung to 
him, and he never lost the splendid accuracy of his touch. During his pre-Raphaelite period he painted some of his noblest pictures - "The Vale of Rest," the "Ophelia," and others which are now in the Tate Gallery. We have here but two of his splendid portraits, that of W. E. Gladstone (I666), and that of the great surgeon, Sir Henry Thompson (I94I). Look at the fire and the tenderness in the eyes of Mr. Gladstone. The portrait was painted in I879, at the time when the Eastern part of Europe was in revolt against Turkish despotism. Then the soul of the great statesman was full of wrath at the idea of liberal England backing Turkey, and going to war for her sake. And in the portrait of Sir Henry Thompson how splendidly the decision, the masterfulness of the spirit of the sitter, are conveyed. We cannot look at these two works without acknowledging the power and insight of Millais' genius.

$\mathrm{He}$ was born in Jersey, and his parents came to London in 1837, and settled in Gower Street. They sent their son to an art school directed by Mr. Sass, and there, at the age of nine, he won a silver medal. At eleven he was admitted to the Academy schools. Before he was seventeen, he had painted his first picture, which was hung in the Royal Academy, and in 1847 he gained the R.A. medal. In 1853, when he was just twenty-four years of age, he was elected an Associate, and, ten years afterwards, he attained the full dignity of Royal Academician. After the death of Lord Leighton, the Presidentship of the Academy was 
offered to Millais. He accepted it, but disease had already marked him for its own, and he died in r896. Those of you who are old enough, must remember the magnificent series of pictures he painted, and how every year, when the Academy opened, there was but one question of interest, "What has Millais painted?"

And now we have finished our tour of the National Gallery. We. have left many pictures unnoticed, but I think we have left out none that are memorable, and that you will be able to trace the peculiarities of each master in his works. The master's genius is the outcome of his time, of his faith and struggles. We have seen how Catholicism reigned over the spirit of Italy and Spain; how Protestantism and love of country inspired the artists of the Low Countries, how charming and cultured artificiality was expressed in French art, and how the art of England declares her strong and insular soul.

Art is the language of the spirit. Poetry, music, painting, sculpture tell us the secret of humanity's dreams. The National Gallery and all the picture galleries throughout the world are shrines of one mode of its expression, and as such are unique and important possessions. 


\section{PICTURES AND PAINTERS}

\section{FLORENTINE SCHOOL}

PAINTER NUMBER PAge

The Madonna and Child . . Cimabue . . . . . 5656

St. John and St. Paul . . . . School of Giotto . . . 276 Io

Coronation of the Virgin . . . " . . 568 Iо

The Virgin and Child . . . Margaritone . . . 564 I I

Coronation of the Virgin . . . Orcagna. . . . . . 569 I2

The Trinity. . . . . . . " . . . . . . 570 I 3

Angels Adoring . . . . . . .

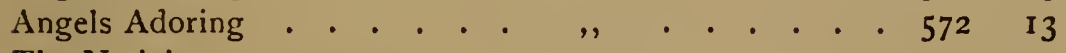

The Nativity . . . . . . . $\quad, \quad$. . . . . . 573 I3

The Adoration of the Magi . . $\quad$ " . . . . . . 574 13

The Resurrection . . . . . . , . . . . . . 575 I3

The Three Maries. . . . . . , , . . . . . . 576 I3

The Ascension . . . . . . . $\quad$, . . . . . . 577 13

The Holy Spirit . . . . . . $\quad$ " . . . . . . 578 13

The Virgin and Child . . . . Filippo Lippi . . . 589 I5

The Vision of St. Bernard . . . , . . . 248 I6

Portrait of Cosmo I. . . . . Bronzino . . . . . 70416

The Annunciation. . . . . . Filippo Lippo . . . . $666 \quad 17$

St. John the Baptist and Saints . " " . . . 667 17

Mars and Venus . . . . . Botticelli . . . . . 915 19

The Nativity of the Saviour . . " . . . . . 103420

The Virgin and Child, St. John

the Baptist and an Angel . . " " . . . . . 275 21

The Assumption of the Virgin . ", . . . . . 112622

Portrait of a Lady . . . . . School of Botticelli . . $20 S_{3} 22$

The Resurrection . . . . . . Fra Angelico . . . . 66323

St. Francis with the Stigmata . . Filipfino Lippi . . . 59825

Angel Adoring . . . . . . . " , . . 92726

The Adoration of the Magi . . $\quad$, $\quad$. . . 59226

The Adoration of the Magi . . $\quad$. $\quad$. . . $\begin{array}{rlrl}5033 & 26\end{array}$ 


\section{FLORENTINE SCHOOL-continued.}

\section{PICTURE}

PAINTER

NUMBER PAGE

The Adoration of the Magi . . Filippino Lippi . . . $1124 \quad 26$

$\begin{array}{lll} & & \\ 27 & & 24 \\ 583 & 28\end{array}$

The Battle of Sant' Egidio . . . Paolo Uccello . . . . 58328

The Death of Procris . . . . Piero di Cosimo . . . 69830

Raphael and Tobias . . . . Antonio Pollajuolo . . 781

Martyrdom of St. Sebastian . . " " . 29233

Portrait of a Girl . . . . . . Domenico Ghirlandajo . 123035

Portrait of a Youth . . . . . " $\quad 129935$

Procession to Calvary . . . . Ridolpho Ghirlandajo . II43 35

The Entombment of Our Lord . Nichael Angelo . . . $790 \quad 36$

The Madonna and Infant Christ,

St. John the Baptist and Angels $\quad$, $\quad$. . . . $809 \quad 39$

Our Lady of the Rocks . . . . Leonardo da Vinci . . 1093 4I

His Own Portrait . . . . . Andrea del Sarto . . 69044

Holy Family . . . . . . . ", . . 1746

The Virgin Adoring the Infant

Christ . . . . . . . . Lorenzo di Credi. . . 64846

Virgin and Child . . . . . . $\quad$ " . . . 59347

The Virgin and Child with St. John Bartolommeo . . . . I 169447

\section{SIENESE SCHOOL}

The Madonna and Child . . Duccio . . . . 566 5I

The Assumption of the Virgin . Matteo di Giovanni. . I155 51

The Procession to Calvary . . . Ugolino. . . . . . II 8952

Madonna and Child . . . . Benvenuto da Siena. . 90952

\section{UMBRIAN SCHOOL}

The Virgin and Infant Christ with

St. John . . . . . . Perugino . . . . 181 55

The Virgin Adoring the Infant

Christ . . . . . . . . " . . . 28855

The Virgin and Child with St.

Jerome and St. Francis . . . . . . . . 107555

The Adoration of the Shepherds . " . . . . I44I 55 


\section{UMBRIAN SCHOOL-continued}

PICTURE

PAINTER

Number Page

The Baptism of Our Lord . . . Ascribed to Perugino . I43I 55

The Madonna and Child . . Giovanni Santi . . 751 58

The Vision of a Knight . . . . Raphael. . . . . 21359

Madonna Degli Ansidei. . . . " . . . . . II7I 60

St. Catherine of Alexandria . . " " . . . . . . 168 6 I

The Madonna, Infant Christ and

St. John (Garvagh Madonna) . , . . . . . . 744 61

The Madonna of the Tower . . $\quad$ " $\quad$. . . . . . . 206962

Portrait of Julius II. . . . . . . . $\quad$ " $\quad$. . . . . . . . $\quad 2762$

The Nativity . . . . . . . Piero della Francesca . 90864

The Baptism of Christ in the River

Jordan . . . . . . . " " . 66565

The Triumph of Chastity . . Signorelli. . . . 91065

The Circumcision . . . . . . " . . . . . I I 2865

The Nativity . . . . . . . " $\quad$. . . . . II33 65

The Story of Griselda . . . Umbrian School (as- $\begin{cases}912 & 66 \\ 913 & 67\end{cases}$ cribed to Pinturicchio) $\{91367$

$\begin{array}{lll}\text { St. Catherine of Alexandria } & 914 & 67 \\ 693 & 68\end{array}$

The Madonna and Child . . . " . . . . 70368

The Return of Ulysses to Penelope " $\quad$. . . . 9I I 68

\section{FERRARESE AND BOLOGNESE SCHOOLS}

The Madonna and Child En-

throned . . . . . . . Cosimo Tura . . . 77270

St. Jerome in the Desert . . . " . . . . 7737 I

The Madonna and Child with

Saints . . . . . . . . Ercole di Grandi. . . III9 7I

The Madonna and Child En.

throned . . . . . . . Tisio da Garofalo. . . 671

The Vision of St. Augustine . . $\quad$, $\quad$. . . 8 I 74

The Holy Family . . . . . . $\quad$, . . I70 74

Christ's Agony in the Garden . . $\quad$ " . . . 64274

St. Hyacinth : Dominican . . . Francesco del Cossa . . 59774

The Madonna and Christ En-

throned with Angels . . . . Lorenzo Costa. . . . 629 


\section{FERRARESE BOLOGNESE SCHOOLS-continued}

PICTURE

PAINTER

NUMBer PAge

A Pietà . . . . . . . Francia (Francesco Rai-

The Virgin and Child and St. bolini). . . . . 18075

Anne Enthroned: Surrounded

by Saints. . . . . . .

$$
\begin{array}{lll}
, \quad & \text { I } 79 \quad 75 \\
& 76
\end{array}
$$

The Adoration of the Magi . Dosso Dossi . . . 64078

\section{PADUAN SCHOOL}

The Triumph of Scipio . . . Andrea Mantegna . . 902 So

Sanison and Delilah . . . . . " . II45 80

The Virgin and Child Enthroned $\quad$ " . . $274 \quad 80$

\section{VENETIAN SCHOOL}

Saints Peter and Jerome . . Antonio Vivarini - . $768 \quad \delta_{3}$

St. Francis and St. Mark . . . $\quad$ " . . $12 S_{4} \delta_{3}$

The Annunciation . . . . . Carlo Crivelli. . . 73984

Christ's Agony in the Garden . . Giovanni Bellini. . . 72685

The Doge Leonardo Loredano in

His State Robes . . . . $\quad, \quad$. . . 18985

Madonna and Child . . . . . $\quad$ ". . 28086

The Blood of the Redeemer . . N , . . . I233 86

St. Peter Martyr . . . . . . $\quad$ " . . . 81286

St. Jerome in His Study . . . Catena . . . . . . 69488

A Warrior Adoring . . . . . (Ascribed to Catena) $\quad \begin{array}{lll}634 & 89\end{array}$

Bacchus and Ariadne . . . . Titian . . . . . . $35 \quad 39$

The Madonna and Child with St.

John the Baptist and St. Cathe-

rine Embracing the Divine

Infant . . . . . . . " . . . . . 63590

Ariosto . . . . . . . . $\quad$. . . . . . 19449

Portrait of a Poet . . . . (Ascribed to Titian). . 636 91

A Knight in Armour. . . . . Giorgione (Barbarelli). 26993

The Adoration of the Magi . . . . 116093

The Garden of Love . . . . . School of Giorgione . . 93093 


\section{VENETIAN SCHOOL-continued.}

PICTURE

PAINTER

Number PAGE

An Unknown Subject . . . . School of Giorgione . . II73 93

St. George and the Dragon . . Tintoretto (Robusti). . 1694

Christ Washing the Feet of His

Disciples .

The Origin of "The Milky Way"

The Family of Darius at the Feet

of Alexander. . . . . . . Veronese (Ca'liari) . . 29495

The Vision of St. Helena . . . M " . IO4I 96

The Raising of Lazarus . . . . Sebastian del Piombo . 197

Portrait of Count Sciarra Ces-

aresco . . . . . . . . . Moretto . . . . . . 29999

Portrait of an Italian Nobleman . " . . . . . . 102599

Portrait of a Lawyer . . . . . Moroni . . . . . . 74299

Portrait of an Ecclesiastic . . . " , . . . . . . 102499

Portrait of a Tailor . . . . . " . . . . . . 69799

Portrait of the Phrothonotary

Apostolic Juliano . . . . . Lorenzo Lotto . . . IIO5 100

Portrait of a Lady. . . . . . Paris Bordone. . . . 674 Ioo

\section{SCHOOLS OF LOMBARDY}

(SCHOOL OF MILAN AND PARMESE SCHOOL)

The Marriage of St. Catherine of

Alexandria . . . . . Ambrogio Borgognone . 298 I02

Family Portraits . . . . . , 779-780 103

Christ Arguing with the Pharisees Bernardino Luini . . I8 103

"Ecce Homo" . . . . . . Correggio . . . . . 15104

The Holy Family . . . . . . " . . . . . 23 I04

Mercury Instructing Cupid in the

Presence of Venus . . . . . . . . . . . I0 I05

Regatta on the Grand Canal . . Canaletto . . . . 938 Io\&

View on the Canal Reggio, Venice $\quad$ " . . . . . 163 . I08

The Magdalen . . . . . . Guido Reni . . . . 177 Io8

The Madonna with the Infant

Christ . . . . . . Sassoferrato . . . 740 Io8

Landscape and Figures . . . Salvatore Rosa . . . 1206108 


\section{SCHOOL OF SPAIN}

PICTURE

PAINTER

NUMBER PAGE

The Dead Christ . . . . . Ribera . . . . . 235 III

A Franciscan Monk. . . . Zurbaran . . . . 230 II 3

The Nativity, or Adoration of the

Shepherds . . . . . . " . . . . . 232 II3

Portrait of Philip IV., King of

Spain . . . . . . Velazquez . . . . I129 I16

Philip IV., King of Spain . . . $\quad$. . . . . 745 I16

Portrait of the Spanish Admiral

Pulido-Pareja . . . . . " . . . . . 1315 II7

Venus and Cupid . . . . . . $\quad$ " . . . . . 2057 I17

Christ at the Column . . . . " . . . . . II48 II7

A Dead Warrior . . . . . Ascribed to Velazquez . 741118

St. John and the Lamb. . . Murillo . . . . . I76 121

The Holy Family . . . . . . " . . . . . . I3 I2I

A Spanish Peasant Boy. . . . " . . . . . . 74 12I

Portrait of Doña Isabel Corbo de

Porcel . . . . . . . . Goya y Lucientes . . I473 I2I

Portrait of Dr. Peral . . . . ,, . . . I95I I2I

\section{FLEMISH SCHOOL}

Portraits of Jean Arnolfini and

Jeanne de Chenany His Wife . Jan van Eyck . . . 186 I 24

A Canon and His Patron Saints . Gerard David . . . 1045125

The Mystic Marriage of St. Cath-

erine

Portrait of a Man Dressed in Black

with Fur over His Shoulders . Mabuse . . . . 656 126

A Man's Portrait . . . . . . . . . . . 946126

Portrait of a Man and His Wife . $\quad$, . . . . . . $1689 \quad 126$

Salvator Mundi, and the Virgin

Mary . . . . . . . Quinten Massys . . $295 \quad 126$

The Deposition in the Tomb . . Rogervan der Weyden 664 I 27

"Mater Dolorosa" . . . . . " $\quad 711 \quad 127$

"Ecce Homo" . . . . . . $\quad$ " $\quad 712 \quad 127$

Husband and Wife. . . . Ascribed to Van der

Weyden. . . . $653 \quad 127$ 


\section{FLEMISH SCHOOL-continued}

PICTURE

PAINTER

Number PaGe

The Magdalen. . . . . . School of Van der

The Virgin and Infant Christ EnWeyden. . . . $654 \quad 127$ throned in a Garden . . . . Memling . . . . . 686 I28

The Madonna and Infant Christ . " . . . . . 709129

St. John the Baptist Holding a Lamb on His Left Arm . . .

The Abduction of the Sabine Women . . . . . . . The Judgment of Paris . . .

Le Chapeau de Paille (Portrait of Susanne Fourment) $\cdot \dot{\cdot} \cdot \cdot$. I., King of Great Britain and Ireland . . . . . . . .

Portrait of Cornelius van der Geest

A Music Party. . . . . . .

Players at Tric-Trac, or Back-

Rubens . . . . . $38 \quad \mathbf{1 3 2}$

" . . . . . $194 \quad 132$

. . . . . $852 \quad 133$

Van Dyck . . . . II72 I 34

$\quad, \quad$. . . . 52 I 34

gammon . . . . . . . .

The Village Fête • • • • " $\quad$ " $\quad 242 \quad 136$ younger)..$\quad$. . $\quad$ I54 I36 The Village Fete. . . . .

\section{DUTCH SCHOOL}

Portrait of a Woman . . . Frans Hals . . . 102 I 139

Portrait of a Man . . . . . . " . . . . I25I I39

His own Portraitwhen Aged About Thirty-two . . . . . . Rembrandt . . . 672 I40

The Painter's own Portrait at an advanced age . . . . . . $\quad, \quad$. . . 221 I40

The Adoration of the Shepherds. " . . . . 47 I4 I

Portrait of a Capuchin Friar . . " . . . . I66 I4 I

A Jewish Rabbi . . . . . . " " . . . . I90 I4I -

Portrait of a Woman. . . . . " . . . . . 237 I4 I

A Man's Portrait . . . . . . " . . . . 243 I4I

Portrait of an Old Lady in Black, with White Cap and Ruff . . $\quad$ " . . . . 775 I4I

A Man's Portrait . . . . . " . . . 850 I4I 


\section{DUTCH SCHOOL-continued}

A Burgomaster. . . . . . . Rembrandt . . . 1674 I4I

Portrait of an Old Lady. . . . " . . . . . 1675 I4I

The Courtyard of a Dutch

House . . . . . . . . Pieter de Hoogh . . . 794142

Courtyard of a Dutch House

Paved with Bricks . . . . $\quad$ " . . . 835142

The Duet . . . . . . Gabriel Metsu . . 838 I43

The Music Lesson . . . . . " " . . 839143

River Scene by Moonlight, with

Shipping . . . . . . . Van der Neer . . 239143

Card Players . . . . . . , Nicolas Maas . . . 1247143

The Idle Servant . . . . . . $\quad$, $\quad$. . . $207 \quad 143$

The Dutch Housewife . . . . " " . . . 159143

The Alchymist . . . . . . Adrian van Ostade . 846144

A Frozen River . . . . . . Isaak van Ostade . . 963144

Portrait of a Young Lady . . . Van der Helst . . . 1248144

The Poulterer's Shop . . . . Gerard Dou . . . . 825144

The Painter's Own Portrait . . " . . . . 192145

The Painter's Wife: Bust . . . $\quad$ " $\quad$. . . . 968145

The Music Master. . . . . J Jan Steen. . . . . 856145

The Peace of Muinster . . . . Gerard Terborch . . 896145

The Guitar Lesson . . . . . $\quad$ " . . . 864147

A Calm at Sea. . . . . Van de Velde (the

younger) . . . . $874 \quad 147$

Dutch Shipping • . . . . Ludolf Bakhuizen . . 223148

River Scene with Cattle . . . Albert Cuyp. . . . 823148

Landscape with Cattle and Figures:

Evening . . . . . . ". . . . 53148

Landscape with Cattle . . . . Paul Potter . . . . 849149

A Landscape with Waterfall . Jacob Ruysdael . . . $627 \quad 150$

An Old Oak . . . . . . . " " . . . 988150

The Broken Tree . . . . . . $\quad$ " . . . 991 150

The Avenue, Middelharnis, Hol-

land . . . . . Meindert Hobbema. . $830 \quad 150$

Landscape, a Party of Muleteers

with Laden Mules: Morning · Jan Both . . . . 71 15I

An Italian Landscape . . . . " . . . . . I9I7 I5I

Landscape with Figures . . . Jan Wynants . . . $884 \quad 152$ 


\section{DUTCH SCHOOL-continued}

PICTURE

PAINTER

Number Page

Landscape, a Hilly Country with

a Few Trees . . . . . . Jan Wynants . . 971

A Battle, Cavalry and Infantry . Philips Wouwerman . $976 \quad 152$

A Full Length Portrait of a Girl. Sir Peter Lely . . . 1016153

A Vase with Flowers . . . . Jan van Huysum . . $796 \quad 153$

A Fruit Piece . . . . . . . Frans Snyders . . . 1252153

Portrait of the Painter's Father . Albrecht Dürer. . . $1938 \quad 156$

Portrait of a Young Lady . . . Lucas Cranach . . . $291 \quad$ I 57

The Ambassadors . . . . Hans Holbein . . . $1314 \quad 158$

\section{FRENCH SCHOOL}

A Man's Portrait . . . . . Ascribed to Clouet . . $66016 \mathrm{I}$

Protrait of a Boy . . . . . . , . I190 I6I

Cephalus and Aurora . . . . Nicolas Poussin . . 65163

A Bacchanalian Festival . . . " . . . 42 I63

A Bacchanalian Dance . . . . $\quad$ " . . . 62 163

A Landscape with Figures, Repre-

senting Abraham and Isaac Go-

ing to the Sacrifice . . . . Gaspard Poussin . . 31 I63

The Calling of Abraham . . . N " . . I159 163

Landscape with Figures, Representing the Marriage Festival of Isaac and Rebecca. . . . $\}$ Gellée) . . . . $\}^{12} 165$

Seaport, with Figures, Representing the Embarkation of the Queen of Sheba, on the Occasion of Her Visit to Solomon.

A Seaport at Sunset . . . . .

Landscape with Figures, Repre-

$\left\{\begin{array}{c}\text { Claude Lorrain (Claude } \\ \text { Gellée) } \cdot \cdot \cdot\end{array}\right\} 12 \quad 165$ senting the Story of Narcissus and Echo.

". $\quad . \quad 14 \quad 165$

The Four Ages of Man . . . . Nicolas Lancret. . . IoI-4 I68.

Study of Still Life . . . . . Siméon Chardin . . 1258169

"La Fontaine" . . . . . . " . . 1664 169

The Head of a Girl . . . . Jean Baptiste Greurs . 206 170

Girl with an Apple . . . . . " " 1020 I70

Head of Girl Looking Up . . $\quad$ " . IOI9 170 


\section{FRENCH SCHOOL-continued}

PICTURE

PAINTER

NUMBER PAGE

Portrait of the Artist . . . . . Mme. Vigke Le Brun. I653 I70 Sunny Days in the Forest . . Diaz de la Pena . . 2058 I7 I

Portrait of Mr. and Mrs. Edwards Fantin Latour . . . 1952 17I

The Marsh Arleux-du-Nord . . Corot . . . . . 2135172

\section{ENGLISH SCHOOL}

His Own Portrait . . . . . Willian Hogarth . II2 I77

Portrait of Miss Fenton, the Actress, as "Polly Peachum" in the "Beggar's Opera" . . The Marriage "À La Mode" . Calais Gate, called also "The Roast Beef of Old England" . Heads of Angels . . . . . . Sir Joshua Reynolds . $182 \quad 179$ The Graces Decorating a Terminal Figure of Hymen . . Mrs. Harley and Child (sometimes called a Nymph with the Infant Bacchus).

The Infant Samuel Kneeling at Prayer.

The Age of Innocence . . . .

Robinetta . . . . . . . .

Portrait of Lord Heathfield, with the Key of the Fortress of Gibraltar in His Hand . . . .

Dr. Samuel Johnson . . . . . Portrait of Mrs. Siddons . . Portrait of Orpin, Parish Clerk of Bradford, Wiltshire . . . . The Market Cart . . . . . The Watering Place . . . . Study of an Old Horse . . . . Landscape with Figures, Representing the Destruction of Niobe's Children . . . . . Richard Wilson. . . I IO $\mathrm{I}_{3}$ Study of Lady Hamilton as a Bacchante . . . . . George Romney . . $312 \quad 185$ 


\section{ENGLISH SCHOOL-continued \\ PICTURE \\ PAINTER \\ NUMBER PAGE}

Sketch Portrait of Lady Hamilton

(Cassandra) . . . . . . George Romney . . 1668185

Portrait of Mrs. Mark Currie . . " . . . I651 185

Portrait of Lieut.-Colonel Bryce

McMurdo. . . . . . . . Sir Henry Racburn . 1435185

Portrait of a Lady (a Member of

the Dudgeon Family). . . . N " II46 185

Portrait, said to Represent Mary

Wollstonecraft (Mrs. Godwin). John Opie . . . . . I167 186

Portrait of William Godwin, the

Author. . . . . . . . " . . . . . 1208186

Portrait of the Countess of Oxford John Hoppner . . . 900 I87

$\begin{array}{llll}\text { Portrait of Mrs. Siddons . . . Sir Thomas Lawrence } & 785 & 187\end{array}$

Portrait of Benjamin West, P.R.A.

$144 \quad 187$

Portrait of the late John Julius

Angerstein, the Banker, and

Collector of the Angerstein

Gallery . . . . . . .

Portrait of Romilly . . . .

689190

Slate Quarries . . . . . . . " . . . . 1037190

The Windmill . . . . . . " $\quad$. . . 926190

River Scene. . . . . . John Cotman . . . IIII I9I

The Inside of a Stable . . . . George Morland. . . I030 I9I

The Pilgrimage to Canterbury . Thomas Stothard . . 1163192

A Greek Vintage, a Dance in the

Vineyard . . . . . .

The Corn Field, or Country

Lane .. . . . . . John Constable . . 130195

The Valley Farm . . . . . . " . . . $327 \quad 196$

The Sun Rising in a Mist . . J. M. W. Turner. . $47916_{5}$

Dido Building Carthage . . . " . . $498 \quad 16_{5}$

The Bay of Baiae, Apollo and the

Sibyl . . . . . . .

The "Fighting Téméraire"

, . $\quad 505 \quad 198$

Tugged to Her Last Berth to

be broken up . . . . . .

Venice

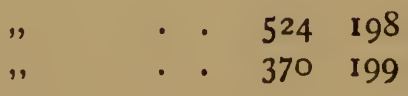




\section{ENGLISH SCIHOOL-continued}

PICTURF

PAINTER

NUMBER PAGE

Ulysses Deriding Polyphenus. . J. M. W. Tumer . . 508199 Approach to Venice, Looking Towards Fusina

The "Sun of Venice" Going to Sea. . . . . . . , . The Garden of the Hespericles . The Death of Nelson. . . . . Childe Harold's Pilgrimage . . Peace: Burial at Sea of the Body of Sir David Wilkie . . . . $\quad$ " . $528 \quad 200$ The Blind Fiddler . . . . . Sir David Wilkie . . 99202 The Village Festival . . . . . $\quad$, . . 122203 The Bagpiper . . . . . . . $\quad$ " $\quad$. 329203 The Spiritual form of Pitt Guiding Behemoth . . . . . . I Illiam Blake . . I Iro 204

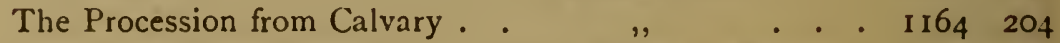
Dignity and Impudence. . . . Sir Edwin Landseer . 604206 Shoeing . . . . . . . . . Spaniels of King Charles's Breed The Sleeping Bloodhound . . . Portrait of Right Hon. W. E.

Gladstone. . . . . . . . Sir John E. Millais . 1666209 Portrait of Sir Henry Thompson, Bart. $\begin{array}{llll}" & \cdot & 606 & 207 \\ " & \cdot & 409 & 207 \\ , & . & 603 & 207\end{array}$ . . . . . . - I94I 209 


\section{NATIONAL GALLERY}

\section{INDEX TO PAINTERS}

AND THEIR WORKS

A

PAGE

Abduction of the Sabine

Women, The, by

Rubens ......... I32

Adoration of the Magi

by Dosso Dossi ... 78

Adoration of the Magi

by Giorgione ..... 93

Adoration of the Magi

by Filippino Lippi 26, 27 Adoration of the Shep-

herds by Rembrandt I4I Adoration of the Shep-

herds by Perugino . 56 Age of Innocence by

Reynolds ........ I80 Ambassadors, The, by

Holbein ...... I58, I59 Angel Adoring, $A n$, by

Filippino Lippi ... 26 Angelico, Fra . 23, 24, I09 Angerstein, Portrait of

Lord, by Lawrence I88 Annunciation by Carlo

Crivelli........8.84, 85 Annunciation by Fil-

ippo Lippi ..... I7, I8. Approach to Venice

by Turner ....... I99
Ariosto by Titian ...90, $9 \mathrm{I}$ Assumption of the

Virgin by Botticelli

22 Assumption of the

Virgin by M. di Giovanni ........ 5I Avenue, The, Middelharnis, Holland, by Hobbema ........ I50

$\mathrm{B}$

Bacchanalian Dance by Poussin ....... I63 Bacchanalian Festival by Poussin ....... I6 1 Bacchante by Romney I $84, \quad$ I 85

Bacchus and Ariadne by Titian .....89, I05 Bagpiper, The, by Wilkie ........203 Bakhuizen ....... 447 , I 48 Baptism of Christ in the River Jordan by Francesca ........ 65 Baptism of our Lord ascribed to Perugino .......... 55

Bartolommeo.....47, 48 
Battle, $A$, Cavalyy and Infantry, by Wouwerman ........ I52

Battle of Sant' Egidio by Uccello......28, 29 Bay of Baiae, Apollo and the Sibyl by Turner ........ rg8 Bellini, Gentile. ... .79, 83 Bellini, Giovanni, 79, 83 $85-86,88,9 \mathrm{I}, 94$, roo Benevenuto da Siena 52 Blake .......... 203 Blind Fiddler, The, by Wilkie .....202, 203 Blood of the Redeemer by Bellini ....... 86 Bonheur ..... I74, I75 Bordone .......... I00 Borgognone ....... I02 Both, Jan ......... I5I Both, Adrian ....... I5I Botticelli, 9, I5, I8-23, 27 , $82, \operatorname{I09}$ Botticelli (School of) . 22 Broken Tree, The, by Ruysdael ........ I50 Bronzino ......... I6 Boucher ...... I68, I69 Bruce Macmerdoe, Lt.Colonel, by Raeburn I 85 Buonaccorso....... 52

C

"Calais Gate" by Hogarth ........ I78 Calling of Abraham by

G. Poussin ...... I6 $6_{3}$

Calm at Sea by Van de Velde ........ I47 Canaletto .. I07-ro8, I09 Canal Reggio (The Grand Canal) by Canaletto ........ I08 Canon, $A$, and his Patron Saints by Gerard David .... I25 Carracci ........... I07 Card Players by $\mathrm{Ni}$ cholas Maas ...... I4 43 Catena ....... 88, 89 Catherine of Alexandria by Pinturicchio 68 Cephalus and Aurora by N. Poussin .... I63 Chapeau de Paille, Le, by Rubens ........ I33 Charles $I$. by Van Dyck ........... I34 Chardin ......... I68, x69 Childe Harold's Pilgrimage by Turner

Christ at the Column, by Velazquez. II7, II 8 Christ Disputing with the Pharisees by Luini ....... I03, I04 Christ's Agony in the Garden by Giovanni Bellini .......... $S_{5}$ Christ's Agony in the Garden by Garofalo Christ Washing the Disciples' Feet by Tintoretto ...... 94 Cimabue .. 2, 5-II, I2, 50 
Circumcision by Sig- ${ }^{\text {PAGE }}$ norelli ........ 65 Claude, I48, I64-I66, I67, Clouet François I95, I97 Cornelius van der Geest by Van Dyck ..... I 34 Constable ...... 194-196 Correggio . I02, I04-I06 Corot ........ I72-I74 Coronation of the Virgin (School of Giotto) ........... Coronation of the Virgin by Orcagna I2, I3

Cosimo ...... 9, 30-32 Costa, Lorenzo ... 74, 75 Cosmo de' Medici by Bronzino ........ I6 Cotman ........... IgI Courtyard of a Dutch House by De Hoogh

I 42, I 43

Cranach .......... 157 Credi, Lorenzo di . 46, 47 Crivelli, Carlo ....... 84 Crome ........ r r89-19I Crossing the Brook by Turner ..........200 Currie, Mrs. Mark, by Romney ......... I85 Cuyp $\ldots \ldots \ldots \ldots \ldots$ I48

\section{$\mathrm{D}$}

David, Gerard ...... I25 Dead Christ, The, by Ribera ..... III-II2
Dead Warrior, The, by Velazquez .... II8-II9 Death of Nelson, The, by Turner ....... I99 Death of Procris, The, by Cosimo ...... 30-32 Dido Building Carthage by Turner ... I65 Dignity and Impudence by Landseer

Diaz de la Pena ..... I7I Doge Leonardo Loredano in his State Robes by Giovanni Bellini ......8 85, 86 Dolci ..... I07, I08, I09 Dosso Dossi ........ 78 Dou .............. I44 Dou : Portrait of himself ......... I 45 Dou: Portrait of his

Wife .......... I 45 Duccio ........ 50-52 Dughet (see Poussin, Gaspard)

Dürer . . 4, I55-I57, I58 Dutch Shipping by

Bakhuizen ....... I48 Dyck, Van, 3, II9, I33I35, I52, I76

E

Ecce Homo by Corregio ........... I04 Edwards, $\quad M r$. and Mrs., by Fantin Latour ......... I7I 
Entombment of Our PAGE Lord by Michael Angelo ........ 36-39 Eyck, Van, 3, 86, I23-I25,

\section{F}

Family Portraits by Brogognone ....... I03 Family of Darius at the Feet of Alexander by Veronese 95, 96

"Fighting Téméraire," The, Tugged to her Last Berth by Turner ......... Ig 8 Fontaine, La, by Chardin ........ I69 Four Ages of Man by Lancret......... I68 Fragonard ......... I67 Francesca, Piero della

Francia ........ 75-78 Franciscan Monk by Zurbaran ........II3 Fruit Piece by Snyders ......... I53

G

Gainsborough, 4, I76, I77, ISo-IS2, I83, I84, I85,

Game of Backgammon I95 by Teniers ....... I36 Garden of Love (school of Giorgione) .....

Garden of the Hesperides, The, by Turner ......... Ig6 Garofalo .......... 73 Garvagh Madonna by Raphael ...... 6I, 62 Gellée (see Claude) Ghirlandajo, Domenico del ........ 34 Ghirlandajo, Ridolfo del ........... 35 Girl with an Apple by Greuze ........ I70 Giorgione, S8, 9I, 92-93, Giotto ....2.2, 9-II, I2 Giotto (School of) ... IO Giovanni, Matteo di

50, 5I, 52 Gladstone, $W . E$., by Millais ........209 Godroin, William, by Opie ......... IS6 Goya ............ I2I Graces Decorating a Statue of Hymen by Rcynolds .... I79, I8o Grandi ......... 7 I Greek Vintage, $A$, by Stothard ........ I93 Greuze ....... I69-I70 Griselda, The Story of

(Umbrian School) . 66 Guercino ........ I07

$\mathrm{H}$

Hals . I38-I39, I43, I44 Hamilton, Lady, as 
INDEX

Bacchante by Rom-

PAGE ney .......... I85

Hamilton, Lady, as Cassandra by Romney ........... I85

Hartley, Mrs., and Child by Reynolds . I80 Head of a Girl by Greuze ......... I70 Head of a Girl Looking $u p$ by Greuze ..... I70 Heads of Angels by Reynolds ........ I79 Heathfield, Porlvait of Lord, by Reynolds . I8o Helst, Van der ...... I44 His own Portrait by Hogarth .... I77, I78 Hobbema .. I50-I5I, I89 Hogarth . 4, I76, I77-I78 Holbein . 4, I55, I57-I60 Holy Family, The, by Andrea del Sarto .. 46 Holy Family by Correggio .......... I04 Holy Family by GaroHoly Family by Murillo ............ I2I Hoppner ...... I86, I87 Horse Fair, The, by Rosa Bonheur .... I74

\section{I}

Infant Samuel by Reynolds ....... I80 Inside of a Stable by Morland ........ I9I

Interior of a Dutch House by De Hoogh

Italian Landscape, $A n$, I 42, I43 by Jan Both ....... I5I Italian Nobleman, Portrait of, by Moretto .......... 99

Jan Arnolfmi and his Wife by Van Eyck

I24-I25

Johnson, Portrait of

$D r$., by Reynolds .. I8o Judgment of Paris by Rubens ......... I32 Julius II. (Pope) by

Raphael ........ 62

K

King Charles Spaniels by Landseer ..... 207 Knight in Armour by Giorgione ....... 93 L

Lancret ...... I68, I69 Landscape: A Party of Muleteers by Jan Both ........... I5I Landscape with Cattle and Figures by Cuyp ........... I4S Landscape with Cattle by Paul Potter .... I I9 
Landscape roith Fig. ures by Salvatore Rosa ........ I08-109 Landscape with Figures by Wynants .. I52 Landscape with Figures representing the story of Narcissus and Echo by Claude I 66 Landscape with Waterfall by Ruysdael .. I50 Landseer ..... 204-207 Latour, Fantin . I7I, I72 Lawrence ...... I87-I88 Lawyer, Portrait of $a$, by Moroni ....... 99 Lely ..... I52-I53, I76 Lippi, Filippo . . 9, I5-I8 Lippi, Filippino . . 2 25-28 Lorenzetti, A. .... 52 Lorenzetti, P...... 52 Longuo .......... I07 Lotto ........... roo Luini ............ Io

\section{M}

Maas ........... I 43

Mabuse ...... I25, I26 Madonna and Child by Giovanni Bellini 86 Madonna and Child by Cimabue .....6, 8 Madonna and Child by Duccio ........ 5I Madonna and Child by Pinturicchio .... 68 Madonna and Child by Santi ........ $5^{8}$
Madonna and Child Enthroned by Cosimo Tura ........ 70 Madonna and Child Enthroned with Angels by Costa 74-75 MadonnaandChildEnthroned by Garofalo Madonna and Child with St. John the Baptist by Titian . 90 Madonna and Infant Christ, St. John the Baptist and Angels by Michael Angelo 39, 40 Madonna Degli Ansidei by Raphael .. 60 Madonna of the Tower by Raphael ..... 62 Madonna of the White Rose by Benvenuto da Siena ....... 52 Magdalen, The, by Guido Reni ...... I08 Magdalen, $A$ Reading (school of Van der Weyden) ....... I27 Market Cart, The, by Gainsborough ..... I82 Man's Portrait by Clouet ......... I6I Mantegna ............ 79 Margaritone ...... II, I2 Marriage d la Mode by Hogarth ........ I78 Marriage of Isaac and Rebecca by Claude ${ }^{6} 5$ Mars and Venus by Botticelli ...... I9, 22 
Martyrdom of St. Se- PAGE bastian (ascribed to Pollajuolo) ... 33, 34 Massys ......... ז26 Mater Dolorosa by Van der Weyden ... I27 Memling .... 126, I27-I28 Mercury Instructing Cupid by Correggio ro5 Metzu ........... I43 Michael Angelo, 9, 34, 36$40,59,65,97$, I09 Mieris, F. van ...... I44 Mieris, W. van ..... I44 Millais .......208-2Io Milky Way, The, by Tintoretto ...... 94 Molenaer ......... I44 Moretto .......... 98 Morland ...... I9I, I92 Moroni ......... 99-I00 Mousehold Heath by

Crome ......... Igo Murillo ........ IIg-I2I Muse, $A$, Instructing a Court Poet by Dossi .......... 78 Music Party, $A$, by Teniers ......... I36 Music Master, The, by Steen ......... I45 Mystic Marriage of St. Catherine by Gerard David .... I25

$\mathrm{N}$

Nativity, The, by Botticelli .....20, 2I
Nativity, The, by Francesca ....... 64 Nativity, The, by Signorelli ....... 65 Nativity, The, by Zurbaran ........ II3 Neer, Van der ...... I43 Netscher ......... I44 Niobe (landscape) by

Wilson ......... I83

$\mathrm{O}$

Old Grey Hunter, The, by Paul Potter ... I49 Old Oak, $A n$, by Ruysdael ........... I50 Opie .......... I85 Orcagna ........ I2, I3 Ostade, A. van ..... I43 Our Lady of the Rocks

by $\mathrm{Da}$ Vinci .... 4I, 42 Oxford, Countess of, by Hoppner ..... I87

$\mathrm{P}$

Peace of Munster, The, by Terborgh .. I45-I47 Peace: Burial at Sea of the Body of Sir David Wilkie by Turner .......2200 Peral, Dr., by Goya . I2I Perugino ..53-56, 58, 59 Phrothonotary Apostolic Juliano by Lotto .......... I00 Philip IV., King of 
Spain, by Velazquez .. ....... II6 Philip IV., King of Spain by Velazquez (another portrait) . II6 Pietd, $A$, by Francia

Pilgrimage to Canter$75-76$ bury, The, by Stothard ...... I92-I93

Pinturicchio ....676-69

Piombo ........ 97-98

Pollajuolo ....... 32-34

"Polly Peachum" by Hogarth ........ I 78 Poet, Portrait of, by Titian ......... gI Pope Julius II. by Raphael ......... Portrait of a Boy by Clouet ........ I6r Portrait of a Girl by Ghirlandajo ...... Portrait of a Girl by Lely

Portrait of a Lady by Bordone ..... IOO-IOI Portrait of a Lady by Raeburn ......... I85 Portrait of a Man and his Wife by Mabuse

Portrait of $a$ Man and his Wife (School of Van der Weyden) . Portrait of a Man by Hals

Portrait of a Sculptor by Andrea del Sarto (reputed to be of himself)

Portrait of a Woman by Hals ......... I39 Portrait of a Young Lady by Cranach . I57 Portrait of a Youth by Ghirlandajo ..... 35 Portrait of the Artist by Vigée le Brun .. I70 Portrait of the Painter's

Father by Dürer .. I56 Potter ........... I49 Poussin, Nicolas, I62, I63, I64, I95

Poussin, Gaspard .... I63 Poulterer's Shop, The, by Dou ...... I44-I45 Procession from Calvary by Blake .... 204 Procession to Calvary by $R$. Ghirlandajo ........ 35 Procession to Calvary by Ugolino ..... 52

\section{Q}

Queen of Sheba, The, by Claude ...... I6 5

R

Raeburn ......... I85

Raibolini (see Francia) Rain, Steam and Speed by Turner ........ 200 Raising of Lazarus by Piombo........ 97 
Raphael, 53, 57-63, 82, St. Catherine of AlexPAGE Raphael and Tobias by Pollajuolo........ 32 Regatta, $A$ State, by Canaletto ........ I08 Rembrandt, I38, I39-I4I, I 42, I44, I 97 Rembrandt, Portraits of, by himself ..... I40 Reni ..... I07, I08, I09 Resurrection, The, by Fra Angelico ... 23, 24 Return of Ulysses to Penelope by Pinturicchio ........ 68 Reynolds, 4, I24, I62, I76, I77, I79-I80, I84, I85, 187

Ribera, II0, III, II2, II6 River Scene byCotman IgI River Scene with Cattle by Cuyp ......... I4 8 Roast Beef of Old England by Hogarth .. I78 Robinetta by Reynolds I8o Romano ........... I07 Romilly, Portrait of,

by Lawrence ..... I 88 Romney ...... I84-I85 Rosa, Salvatore 107, I08, IO9

Rubens . 3, I30-I33, I53 Ruysdael .. I49-I50, I52

\section{S}

Sacrifice of Isaac by

G. Poussin ....... I6 3 andria by Raphael St. Francis and the Stigmata by Filippino Lippi .... 25, 26 St. George and the Dragon by Tintoretto ......... 94

St. Helen by Veronese .......... 96

St. Hyacinth : Dominican by Cossa .... 74 St. Jerome in his Study by Catena ....... 88 St. Jerome in the Desert by Tura .... 7 I St. John and the Lamb by Murillo ....... I2I St. John and St. Paul (School of Giotto) . Io St. John the Baptist and Saints by Filippo Lippi ...... I7, I8 St. Peter Martyr by Bellini ......86, 87 Salvator Mundi and the Virgin Mary by Massys ......... I26 Samson and Delilah by Mantegna .... 8 80 Santi, Giovanni .. 57, 58 Sarto ... 9, 44-46, I09 Sassoferrato .... I07, I08 Sciarra Cesaresco, Count of, by Moretto .......... 99 Seaport at Sunset by Claude ......... I66 Seaport with the Em- 
PAGE

Jation of $S t$. Ursula by Claude . I66 Shoeing the Bay Mare by Landseer ...... 207 Shrimp Girl, The, by Hogarth ........ I78 Siddons, Mrs., by Gainsborough .... I 8 I Siddons, Mrs., by Lawrence ........ I87 Signorelli .... 59, 65-66 Slate Quarries by Crome ......... Igo Snyders .......... I53 Spanish Admiral Pulida Pareja, The, by Velazquez ..... II7 Spanish Lady, $A$, by Goya ........... I2I Spanish Peasant Boy by Murillo ....... I2I Spiritual Form of Pitt Guiding Behemoth by Blake .......204 Steen ............ I45 Stothard ...... I92-I93 Study of an Old Horse by Gainsborough . I82 Sunny Days in the Forest by Diaz ... I7I "Sun of Venice," The, by Turner ........ I99 Sun Rising in a Mist by Turner ...... I65

\section{$\mathrm{T}$}

Tailor, Portrait of $A$, by Moroni ....... Teniers ....... I I35-I37 Terborgh ...... I45-I47 Thompson, Sir Henry, by Millais ....... 209 Tiepoli .......... I07 Timoteo-Vite ...... 58 Tintoretto, 88, 93-94, 95, 107, 109 Titian, 88, 89-92, 93, I05, Triumph of Chastity, The, by Signorelli . 65 Triumph of Scipio, The, by Mantegna . 80 Tura .........70, 7 I Turner, I24, I65, I94, I97-200

\section{$\mathrm{U}$}

Uccello ...... 28, 29 Ugolino ......... 52 Ulysses Deriding Polyphemus by Turner . I99 Unknown Subject, $A n$ (School of Giorgione) ......... 93

\section{V}

Valley Farm, The, by

Constable ....... I96 Vannucci, Pietro .... 53 Velazquez, IIo, II2, II4Vase with Flowers by Van Huysum .... I53 Velde, Van de ...... I 47 Venice, by Turner .. I99 
Venus and Cupid by
Velazquez Verrocchio ....... 54 Veronese, Paul, 84, 88, 94, 95,97, I09

Vigée le Brun ....... I70 Village Clerk, The, by Gainsborough .... I8I Village Festival, The, by Wilkie ....... 203 Village Fête, $A$, by Teniers ........ I37 Vinci, 9, 4I-43, 59, 82, Virgin Adoring, The, 9I, 109 by Credi .....4 46, 47 Virgin Adoring the Infant Christ by Perugino ....... 55 Virgin and Child and St. Anne Enthroned by Francia ..... 75, 76 Virgin and Child by Botticelli ........ Virgin and Child by Credi ............

Virgin and Child by Filippo Lippi .. I5, I6 Virgin and Child by Mantegna ......8 80, 8I Virgin and Child by Margaritone ...... Virgin and Child by Sassoferrato ...... I08 Virgin and Child with St. John by Bartolommeo

Virgin and Child with St. Jerome and St.
Francis by Perugino .......... 55 Virgin and Child with St. John and St. William by Grandi 7I, 72, 73

Virgin and Child with the two St. Catherines by Borgognone ....... I02, I03 Virgin and Infant Christ Enthroned in a Garden by Memling $\ldots \ldots \ldots \ldots$ I 28 Virgin and Infant Christ with St. John by Perugino ...... 55 Virgin of the Rocks by da Vinci ...... 4I $V i$ sion of a Knight by Raphael ..... 59, 60 Vision of St. Augustine by Garofalo . . 74 $V$ ision of St. Bernard by Filippo Lippi I6, I7 Vivarini ....8 83, I00

\section{W}

Warrior Adoring the Infant Christ by Catena ........ 89 Watering Place, The, by Gainsborough . $\mathrm{I} 82$. Watteau ..... I67, I68 Weenix ......... I53 West, Portrait of Benjamin, by Lawrence I 87, I 88 
Weyden, Roger van der ........70, I26

Windmill, The, by Crome ......... Igo Wilkie ..... 20I-203 Wilson, .... I83, I84, I90,

PAGE

PAGE Wollstonecraft, Mary, by Opie ......... I86 Wouwerman ....... I52 Wynants ...... I5I-I52 Z

I95 Zurbaran . . II0-II3, II6

\section{THE END}

Printed by Baliantrane, Hanson $\&$ Co., Fdinburgh $\&$ London. 



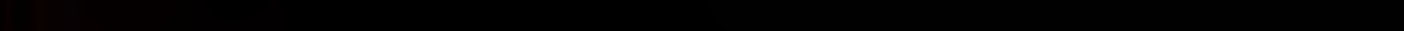




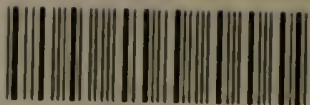 \\ 3.

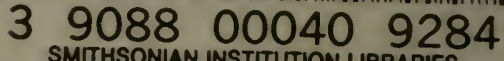 SMITHSONIAN INSTITUTION UIBRARIES}

